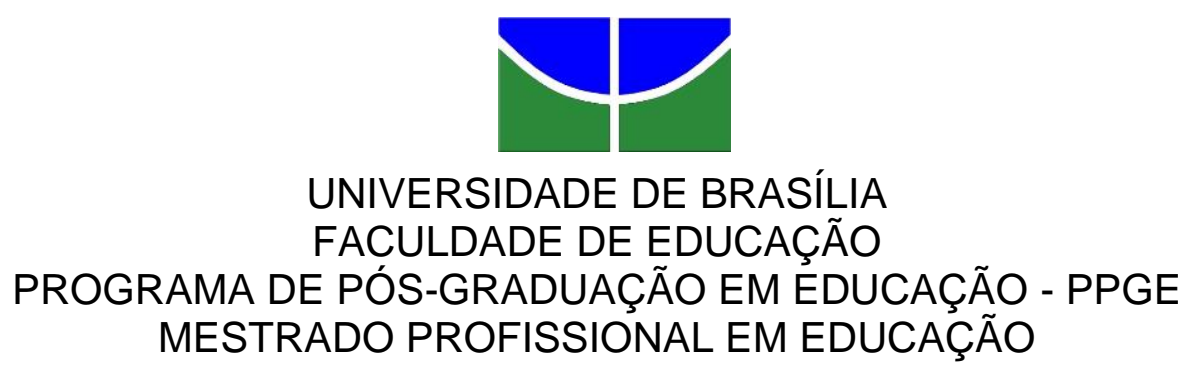

VÂNIA MARIA LOURENÇO

\title{
LIMITES E POSSIBILIDADES DO ENEM NO PROCESSO DE DEMOCRATIZAÇÃO DO ACESSO À EDUCAÇÃO SUPERIOR BRASILEIRA
}


VÂNIA MARIA LOURENÇO

\section{LIMITES E POSSIBILIDADES DO ENEM NO PROCESSO DE DEMOCRATIZAÇÃO DO ACESSO À EDUCAÇÃO SUPERIOR BRASILEIRA}

Dissertação de Mestrado apresentada à Faculdade de Educação da Universidade de Brasília como requisito parcial para obtenção do título de mestre em Educação, área de concentração: Gestão de Políticas Públicas e Sistemas Educacionais. 


\title{
VÂNIA MARIA LOURENÇO
}

\section{LIMITES E POSSIBILIDADES DO ENEM NO PROCESSO DE DEMOCRATIZAÇÃO DO ACESSO À EDUCAÇÃO SUPERIOR BRASILEIRA}

\begin{abstract}
Dissertação apresentada ao Programa de Pós-Graduação em Educação - PPGE da Universidade de Brasília, como parte das exigências necessárias para a obtenção do título de Mestre em Educação Profissional, área de concentração: Gestão de Políticas Públicas e Sistemas Educacionais. Defendida em 23 de março de 2016. Aprovada pela Banca Examinadora, constituída pelos professores:
\end{abstract}

Prof. ${ }^{a}$ Dr. ${ }^{\text {a }}$ Girlene Ribeiro de Jesus (Orientadora)

Faculdade de Educação - UnB

Prof. Dr. Kátia Augusta Curado Pinheiro Cordeiro da Silva Faculdade de Educação - UnB (Membro)

Prof. Dr. Mauro Luiz Rabelo

Instituto de Ciências Exatas -UnB (Membro)

Prof. Dr. José Vieira de Sousa

Faculdade de Educação - UnB (Suplente) 
Dedico esta pesquisa àqueles que sempre financiaram a educação superior e que nem sempre tiveram acesso a ela: a classe popular. 


\section{AGRADECIMENTOS}

Primeiramente agradeço a Deus, que permitiu que todos os caminhos me fizessem chegar até aqui.

À Universidade de Brasília, por ter me propiciado desde a graduação, educação pública, gratuita e de qualidade. Ao Decano de Pós-Graduação, Professor Jaime Santana, pelo apoio aos mestrados profissionais e ao Programa de Mestrado em Educação, pela contribuição à minha formação profissional.

À Professora Girlene Ribeiro, pela paciência em todo o processo de orientação, aos Professores Kátia Curado e Mauro Luiz Rabelo, pela honra de poder contar com suas presenças, comentários e reflexões, e ao Professor José Vieira, pela atenção dispensada durante todo o curso.

Ao amigo e mestre Fernando Garcez e à Mary Angotti, pela acuidade e disponibilidade permanente, desde o momento da minha preparação para a seleção de mestrado.

Às amigas, Kênia, Loide, Lúcia e Marinalva, pelo companheirismo e pelos momentos de descontração.

Ao Rafael Zonta e Marília (DDS/UnB), Ari e Bacelar (SAA/UnB) e Danilo (DEG/UnB), pelos esclarecimentos e informações prestadas de forma generosa, em perfeita conformidade com suas condutas profissionais no dia-a-dia.

À Professora Wilsa Ramos, Antônia Célia e toda a equipe do CEAD, por compreender a minha necessidade de flexibilizar o horário de trabaho, no transcorrer do curso.

À minha enteada, Paula Kielse, por me manter no prumo acadêmico no momento que questões extra-mestrado me impeliam a abandonar este projeto.

À minha mãe e aos meus filhos Felipe, Guilherme e Giovana, pela compreensão quanto à minha ausência no período de estudos, Ao Felipe pelo apoio, à Giovana pelas palavras de incentivo nos momentos de dificuldade e pelas aulas de inglês, às noras Camila e Tamiris, e à toda a família, pela torcida quanto ao sucesso na conclusão do curso.

Especialmente agradeço ao Davi, meu marido e companheiro e ao meu filho Gui, pelo incansável suporte, paciência e parceria ao longo desta caminhada, sem os quais realmente eu não teria superado as dificuldades.

Os presentes agradecimentos não se restringem às pessoas citadas, mas se estendem a todos que de alguma forma contribuíram para a elaboração deste trabalho. 


\section{RESUMO}

A presente pesquisa, de abordagem quantiqualitativa, situa-se no campo das políticas públicas educacionais e pretendeu verificar se o Enem, a partir de sua reformulação ocorrida em 2009, tem contribuido para a democratização do acesso à educação superior, e ainda, de que forma as políticas implementadas pela Universidade de Brasília (UnB) têm favorecido a permanência dos alunos atendidos pela instituição. Para a análise quantitativa, foram considerados os alunos ingressantes nos cursos de Direito, Engenharia (Civil, Elétrica, Florestal e Mecânica), História, Matemática, Medicina e Pedagogia, que ingressaram mediante vestibular, no semestre 2013/2, e pelo Enem, no ano de 2014. As bases de dados foram disponibilizadas pelo Centro de Seleção de Eventos - CESPE/UnB e pelo Decanato de Ensino de Graduação $\mathrm{DEG} / \mathrm{UnB}$, com as quais foram realizadas estatísticas descritivas e inferenciais, considerando-se as variáveis origem regional, tipo de escola cursada no ensino médio (pública ou privada) e renda familiar, relacionando-as com a forma de ingresso e o prestígio social dos cursos. Os resultados das análises quantitativas apontaram que a adoção do Enem tem favorecido a migração de alunos de outras Unidades da Federação, de forma mais expressiva, para os cursos de alto prestígio social, oriundos de escolas privadas e em sua maioria com renda famliar entre três e dez salários mínimos. Observou-se discreta evolução no quantitativo de ingressantes oriundos de escolas públicas, sobretudo em cursos de baixo prestígio social, sugerindo que a condição socioeconômica do indivíduo continua exercendo influência direta quanto ao lugar a ser ocupado pelo aluno dentro da universidade e desconstruindo a ideia de democratização do acesso. Para a análise qualitativa foram aplicados questionários aos alunos beneficiários de políticas de permanência oferecidas pela Universidade de Brasília, no semestre 2014/1, por meio da qual, inferiu-se que, embora haja críticas por parte dos alunos sobre o valor e quantidade dos auxílios oferecidos, bem como sobre 0 gerenciamento dos Programas de Permanência, estas têm colaborado sobremaneira para sua manutenção na instituição.

Palavras-Chave: Enem; SiSU; Universidade de Brasília; democratização do acesso; politicas de permanência. 


\begin{abstract}
The present study, of quantitative and qualitative approach, is in the field of educational public policy. It intended to verify how much the Enem, since its reformulation in 2009, contributes to the democratization of higher education, and whether or not it has favoured student retention. For the quantitative analysis, students enrolled in Law, Engineering (Civil, Electronic, Forest and Mechanical), History, Mathematics and Pedagogy were considered, having entered University through entrance exam (vestibular) in the second semester of 2013 or through national exam (Enem) in the first semester of 2014. Databases were made available by the Centre of Event Selection CESPE/UnB and by the Deanery of Undergraduate Studies - DEG/UnB, with which descriptive and inferential statistics were made, considering the variables regional origin, type of high school attended (private or public) and family income, correlating them to the entrance type and degrees' social prestige. The results of the quantitative analysis point out that the adoption of Enem by the University of Brasilia, regarding the aforementioned degrees, has favoured the migration of students from other states, notably from private schools, to degrees of high social prestige, mostly from families that earn between three to ten times the minimum salary. For the qualitative analysis, questionnaires were given to students who benefit from retention policies by the University of Brasília, in the first semester of 2014, through which it was inferred that in spite of criticism regarding the amount and quantity of financial aid, as well as the management of the Retention Programs, such policies have greatly contributed to student persistence at the institution.
\end{abstract}

Keywords: Enem; SiSU; University of Brasilia; access democratization; retention policy. 


\section{LISTA DE ILUSTRAÇÕES}

\section{GRÁFICOS}

GRÁFICO 2.1 - Demonstrativo do número de instituições participantes do SiSU ( 2010 a 2016)

GRÁFICO 2.2 - Crescimento do número de vagas ofertadas pelas Instituições de Ensino Superior, por meio do SiSU (2010 a 2016)

GRÁFICO 2.3 - Demonstrativo da evolução do número de inscritos no SiSU (2010 a 2016)

GRÁFICO 2.4 - Número de inscritos no Enem (1998 a 2015)

GRÁFICO 2.5 - Evolução do orçamento destinado à Assistência Estudantil no período 2008 - 2013 (em milhões).

GRÁFICO 3.1 - Proporção de alunos que residiam no Distrito Federal antes do ingresso na Universidade de Brasília, e de alunos oriundos de outras Unidades Federativas, conforme a forma de ingresso (Vestibular 2013/2 e Enem (SiSU) (2014/1) em cursos de alto prestígio social.....

GRÁFICO 3.2 - Proporção de alunos que residiam no Distrito Federal (DF) antes do ingresso na Universidade de Brasília, e de alunos oriundos de outras Unidades Federativas (UFs), segundo forma de ingresso (Vestibular 2013/2 e Enem (SiSU) 2014/1) em cursos de baixo prestígio social

GRÁFICO 3.3 - Número de respondentes ao questionário, (A) que tiveram reprovação, (B) que realizaram trancamento de disciplina durante a realização do curso, e (C) que já estiveram em condição de desligamento

GRÁFICO 3.4 - Nível de satisfação de alunos beneficiários, no semestre 2014/1, por políticas de permanência disponibilizadas pela Universidade de Brasília.

GRÁFICO 3.5 - Nível de importância das políticas de permanência oferecidas pela Universidade de Brasília, na percepção dos alunos por elas atendidos no semestre 2014/1 


\section{QUADROS}

QUADRO 1.1 - Evolução do número de matrículas no ensino superior instituições públicas e privadas (1945 - 2013) .................. 30

QUADRO 1.2 - Evolução do número de Instituições de ensino superior privadas e públicas (1995 - 2013)

QUADRO 3.1 - Categoria de renda familiar utilizada para avaliar o perfil socioeconômico dos alunos da amostra, segundo as bases de microdados do Enem (SiSU)

QUADRO 3.2 - Melhorias nas políticas de assistência estudantil já implementadas pela UnB, ou sugestões de outras ações, na percepção dos alunos respondentes ao questionário...

\section{LISTA DE TABELAS}

TABELA 3.1 - Número de vagas ofertadas e número de vagas preenchidas na UnB, por meio do Vestibular, no semestre 2013/2, e pelo Enem (SiSU), no semestre 2014/1, nos cursos de Direito, Engenharia (Civil, Elétrica, Florestal e Mecânica), História, Matemática, Medicina e Pedagogia.

TABELA 3.2 - Vagas para os cursos de Direito, Engenharia (Civil, Elétrica, Florestal e Mecânica), História, Matemática, Medicina e Pedagogia), remanescentes do Enem(SiSU), e ocupadas pelos alunos inscritos na Lista de espera da

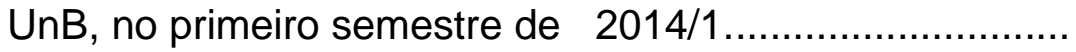

TABELA 3.3 - Frequência e porcentagem de alunos ingressantes, nos cursos de alto prestígio social - Direito, Engenharias (Civil, Elétrica, Florestal e Mecânica) e Medicina, e nos cursos de baixo prestigio social - História, Matemática e Pedagogia, considerando residência ou não no Distrito Federal, antes do ingresso na Universidade de Brasília, e a forma de ingresso dos alunos. 
TABELA 3.4 - Porcentagem de alunos que residiam no Distrito Federal antes do ingresso na Universidade de Brasília, e de alunos que migraram de outras Unidades Federativas (UFs), conforme curso e forma de ingresso (Vestibular 2013/2 e Enem (SiSU) 2014/1)

TABELA 3.5 - Número de ingressantes mediante Enem(SiSU) no semestre 2014/1, nos cursos de Direito, Engenharia (Civil, Elétrica, Florestal e Mecânica), História, Matemática, Medicina e Pedagogia da Universidade de Brasília, considerando sua Unidade da Federação de origem

TABELA 3.6 - Frequência e porcentagem de alunos que ingressaram na Universidade de Brasília, nos cursos considerados de alto prestígio social - Direito, Engenharia (Civil, Elétrica, Florestal e Mecânica) e Medicina, e nos cursos de baixo prestígio social - História, Matemática e Pedagogia, conforme 0 tipo de escola cursada no ensino médio(pública ou privada) e a forma de ingresso

TABELA 3.7-Porcentagem de alunos que ingressaram na Universidade de Brasília, considerando o prestígio social dos cursos, tipo de escola cursada no ensino médio e forma de ingresso (Vestibular 2013/2 e Enem(SiSU) 2014/1)

TABELA 3.8 - Frequência e porcentagem de ingressantes nos cursos de Direito, Engenharia (Civil, Elétrica, Florestal e Mecânica),História, Matemática e Pedagogia, da Universidade de Brasília, mediante vestibular no semestre 2013/2 ou pelo Enem(SiSU), no semestre $2014 / 1$, conforme a renda familiar

TABELA 3.9 - Renda familiar, em porcentagem, dos ingressantes na Universidade de Brasília mediante Vestibular, no semestre 2013/2, e via Enem(SiSU), no semestre 2014/1, nos cursos de Direito, Engenharia (Civil, Elétrica, Mecânica, Florestal), História (Bacharelado e Licenciatura), Matemárica (Bacharelado e Licenciatura), Medicina e Pedagogia 
TABELA 3.10 - Número de alunos matriculados nos cursos de Direito, Engenharia (Civil, Elétrica, Florestal e Mecânica), História, Matemárica e Medicina, matriculados no Campus Darcy Ribeiro, beneficiários de políticas de permanência da Universidade de Brasília, no semestre 2014/1, e número de alunos que responderam o questionário aplicado.

TABELA 3.11 - Frequência de respondentes ao questionário, matriculados nos cursos de Direito, Engenharia (Civil, Elétrica, Florestal e Mecânica), História, Matemática, Medicina e Pedagogia da Universidade de Brasília, conforme forma de ingresso e residência, ou não, no Distrito Federal, antes do ingresso no curso.....................

TABELA 3.12 - Nível de escolaridade do pai e da mãe dos alunos respondentes ao questionário, matriculados nos cursos de Direito, Engenharia (Civil, Elétrica, Florestal e Mecânica), História, Matemática, Medicina e Pedagogia..

TABELA 3.13 - Frequência de alunos solicitantes de políticas de permanência da Universidade de Brasília, matriculados nos cursos de Direito, Engenharia (Civil, Elétrica, Florestal e Mecânica), História, Matemática, Medicina e Pedagogia, considerando o tipo de escola cursada no ensino médio (pública ou privada).

TABELA 3.14 - Número de respondentes que recebem ou não auxílio financeiro da família para manter-se na Universidade de Brasília, e de alunos que realizam ou não atividade profissional remunerada

TABELA 3.15 - Número de alunos que são beneficiários de políticas de permanência disponibilizadas pela Universidade de Brasília, e tipo de auxílio utilizado 


\section{LISTA DE APÊNDICES}

APÊNDICE 1 Solicitação de dados para pesquisa de Mestrado ao Decanato de Graduação - DEG/UnB

APÊNDICE 2 Solicitação de dados para pesquisa de Mestrado ao DDS/UnB

APÊNDICE 3 Questionário aplicado aos alunos dos cursos de Direito, Engenharia (Civil, Elétrica, Florestal e Mecânica), História, Matemática e Medicina, solicitantes, no semestre 2014/1, de políticas de permanência oferecidas pela UnB

\section{LISTA DE SIGLAS}

$\begin{array}{ll}\text { ANDIFES } & \begin{array}{l}\text { Associação Nacional dos Dirigentes das Instituições Federais } \\ \text { de Ensino Superior }\end{array} \\ \text { BID } & \text { Banco Interamericano de Desenvolvimento } \\ \text { BNDES } & \text { Banco Nacional do Desenvolvimento } \\ \text { CAC } & \text { Câmara de Assuntos Comunitários } \\ \text { CAPES } & \text { Coordenação de Aperfeiçoamento de Pessoal de Nível } \\ & \text { Superior } \\ \text { CENSUP } & \text { Censo da Educação Superior } \\ \text { CEPAL } & \text { Comissão Econômica para América Latina e o Caribe } \\ \text { CESPE } & \text { Centro de Seleção e Promoção de Eventos } \\ \text { CEPE } & \text { Conselho de Ensino, Pesquisa e Extensão } \\ \text { CF } & \text { Constituição Federal da República } \\ \text { CNE } & \text { Conselho Nacional de Educação } \\ \text { CNJ } & \text { Conselho Nacional de Justiça }\end{array}$

CNPQ Conselho Nacional de Desenvolvimento Científico e 
Tecnológico

DADREG Dados de Registro de alunos da Graduação

DEG Decanato de Graduação da Universidade de Brasília

DDS Diretoria de Desenvolvimento Social

ENADE Exame Nacional de Desempenho do Estudante

ENEM Exame Nacional do Ensino Médio

FHC Fernando Henrique Cardoso

GEMAA Grupo de Estudos Multidisciplinares da Ação Afirmativa

IBGE Instituto Brasileiro de Geografia e Estatística

IFES Instituição Federal de Ensino Superior

INEP Instituto Nacional de Pesquisas Educacionais Anísio

IRA Índice de Rendimento Acadêmico

LDB Lei de Diretrizes e Bases da Educação

MCT Ministério da Ciência e Tecnologia

MEC Ministério da Educação

PAS Programa de Avaliação Seriada

PBP/MEC Programa de Bolsa de Permanência do Ministério da Educação

PCE/CREDUC Programa de Crédito Educativo

PEIES Programa Experimental de Ingresso ao Ensino Superior

PISA Programa Internacional de Avaliação de Alunos

PNAD Pesquisa Nacional por Amostra de Domicílios

PNAES Programa Nacional de Assistência Estudantil

PNE Plano Nacional de Educação

PNUD Programa das Nações Unidas para o Desenvolvimento

QSC Questionário Socioeconômico

QSE Questionário Socioeducacional

REUNI Reestruturação e Expansão das Universidades Federais

SAA Secretaria de Assuntos Acadêmicos

SAT Scholastic Aptitude Test

SESU Secretaria de Educação Superior 


$\begin{array}{ll}\text { SETEC } & \text { Secretaria de Educação Profissional e Tecnológica } \\ \text { SIGRA } & \text { Sistema de Graduação } \\ \text { SISU } & \text { Sistema de Seleção Unificada } \\ \text { SISUTEC } & \text { Sistema de Seleção Unificada da Educação Profissional e } \\ & \text { Tecnológica } \\ \text { SPS/UnB } & \text { Serviço de Programas Sociais/Universidade de Brasília } \\ \text { UF } & \text { Unidade da Federação } \\ \text { UFAL } & \text { Universidade Federal de Alagoas } \\ \text { UFBA } & \text { Universidade Federal da Bahia } \\ \text { UFMG } & \text { Universidade Federal de Minas Gerais } \\ \text { UFPE. } & \text { Universidade Federal de Pernambuco } \\ \text { UFRJ } & \text { Universidade Federal do Rio de Janeiro } \\ \text { UFSM } & \text { Universidade Federal de Santa Maria } \\ \text { UNB } & \text { Universidade de Brasília } \\ \text { UNE } & \text { União Nacional dos Estudantes } \\ \text { UNESCO } & \text { Organização das Naçães Unidas para a educação, a ciência } \\ & \text { e a cultura } \\ \text { UNICEF } & \text { Fundo das Nações Unidas para a Infância } \\ \text { USP } & \text { Universidade de São Paulo } \\ \text { UNIBAN } & \text { Universidade Anhanguera }\end{array}$




\section{SUMÁRIO}

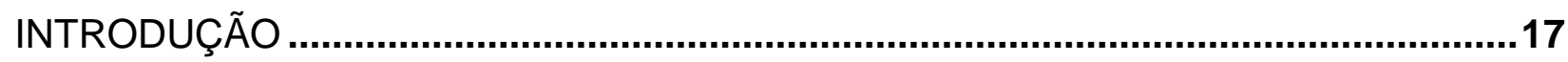

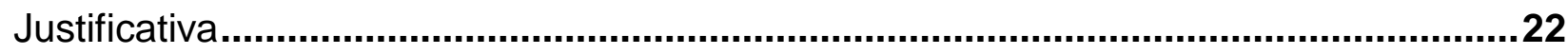

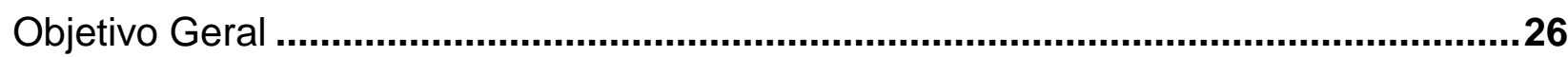

\section{CAPÍTULO 1}

\section{EVOLUÇÃO HISTÓRICA E DEMOCRATIZAÇÃO DO ACESSO À EDUCAÇÃO} SUPERIOR BRASILEIRA

1.1. Educação superior no Brasil, do período colonial até a década de 1930 .........27

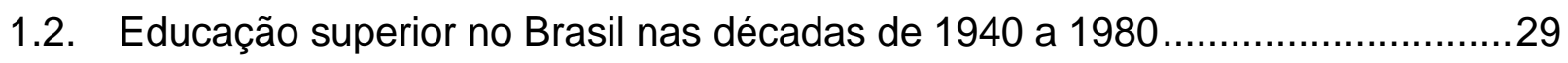

1.3. Educação superior durante as décadas de 1990 a 2000 ...............................32

1.3.1 Expansão da educação superior no governo Fernando Henrique Cardoso

e a influência dos Organismos Internacionais ......................................33

1.3.2 Expansão da educação superior no governo Luiz Inácio Lula da Silva ...36

1.4. Concepções acerca da democratização do acesso à educação superior

CAPÍTULO 2

DIVERSIFICAÇÃO NAS FORMAS DE ACESSO E POLÍTICAS DE PERMANÊNCIA NA UNIVERSIDADE DE BRASÍLIA

2.1 Diversificação na forma de acesso à Universidade de Brasília ...........................50

2.2 Histórico do Exame Nacional do Ensino Médio - Enem .........................................53

2.3 Políticas de permanência na Universidade de Brasília .........................................64

CAPÍTULO 3

METODOLOGIA E RESULTADOS

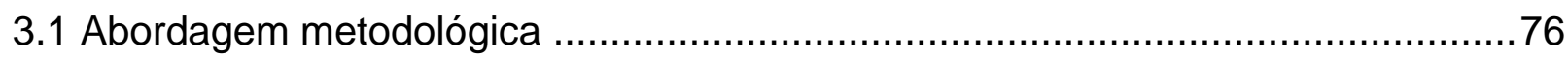

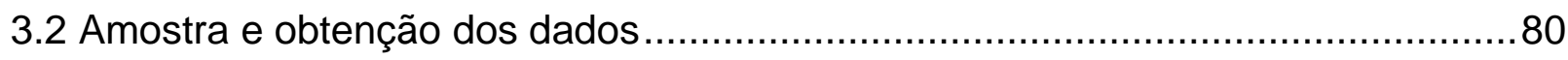

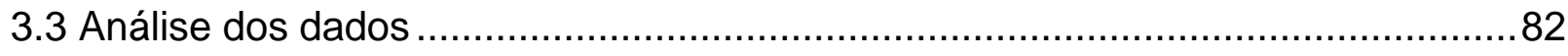




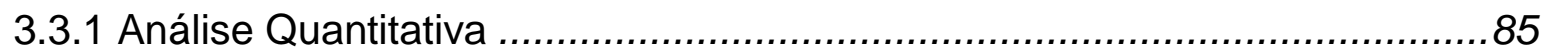

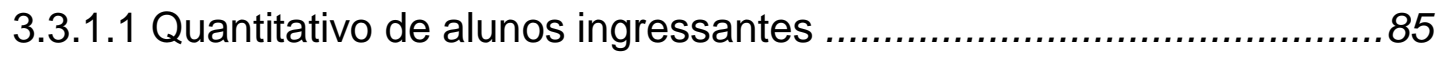

3.3.3.2 Mobilidade regional dos estudantes ............................................ 89

3.3.3.3 Tipo de escola cursada no ensino médio .....................................96

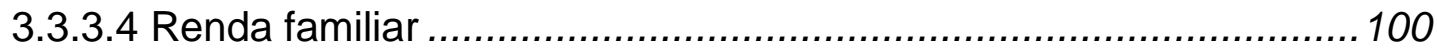

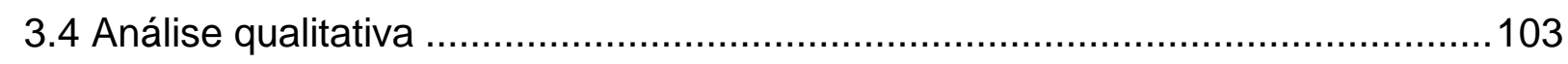

CONCLUSÃO E CONSIDERAÇÕES FINAIS ….....................................................117

REFERÊNCIAS BIBLIOGRÁFICAS ...............................................................128

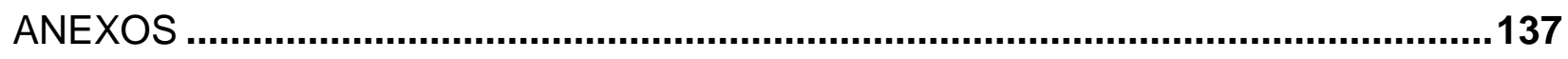




\section{INTRODUÇÃO}

A preocupação deste estudo está voltada para a parcela da população que, em razão de sua condição socioeconômica, esteve historicamente alijada do acesso à educação superior ${ }^{1}$, e inserida em um cenário educacional seletivo e elitista, no qual os processos seletivos para ingresso nas instituições públicas têm priorizado os alunos com maior capital cultural, para a ocupação de suas vagas.

Por muito tempo, a meritocracia justificou o discurso da impossibilidade do acesso de minorias sociais às vagas em universidades públicas. Somente aqueles mais preparados mereciam ocupar tais vagas. Esses discursos objetivavam dissimular as desigualdades educacionais e legitimá-las em desigualdades sociais, por meio de classificações e desclassificações (BOURDIEU, 1984).

A aprovação da Constituição Federal de 1988 representou avanço no campo dos direitos sociais, manifestados em uma nova institucionalidade conferida às políticas sociais públicas. Garantiu, em seu artigo 208, o acesso ao ensino obrigatório e gratuito como direito público e subjetivo do cidadão. No que se refere à educação superior, oito anos após a promulgação da Constituição Federal, a Lei de Diretrizes e Bases da Educação Nacional - LDB (Lei n. 9.394/1996) fortaleceu o panorama do acesso quando, em seu artigo 44, concedeu autonomia às universidades para o estabelecimento de novas formas de ingresso.

$\mathrm{Na}$ história recente, há unanimidade nos campos acadêmico e político quanto à importância da expansão da educação superior para a melhoria das condições socioeconômicas do país. Essa ideia fortaleceu-se a partir da década de 1990, quando houve aumento da demanda por vagas nas universidades brasileiras e o tema democratização passou a fazer parte da agenda de políticas públicas.

Segundo dados do Censo da Educação Superior (BRASIL, 2013), nos últimos 25 anos, o Brasil vivenciou crescimento no número de ingressantes na educação superior. No início da década de 90, somavam-se 1.540 .080 estudantes matriculados nesse nível de ensino. Esse número saltou para 2.694.245 em 2000, e chegou a aproximadamente, 7.300.000 em 2013.

\footnotetext{
${ }^{1}$ Embora na literatura sobre educação brasileira seja comum o uso da expressão ensino superior, neste trabalho optou-se pela expressão educação superior, considerando-se a amplitude a ela atribuída, a partir do advento da LDB/96, quando passou a ser entendida como direito e bem público, extrapolando a mera transmissão de conhecimentos.
} 
Ainda que se tenha observado aumento significativo nas matrículas das Instituições de Ensino Superior - IES, é fato que as vagas ofertadas não são suficientes para atender a demanda de estudantes que almejam esse nível de ensino. Conforme levantamento do Instituto Brasileiro de Geografia e Estatística IBGE (BRASIL, 2010), no universo de 23,03 milhões de jovens na faixa etária de 18 a 24 anos, somente 3,36 milhões estavam matriculados na educação superior naquele ano. Desse modo, o Brasil não atingiu a meta proposta pelo Plano Nacional de Educação - PNE (2001-2010) quanto à pretensão de inserir na educação superior, até o fim da década, 30\% da população na faixa etária de 18 a 24 anos, sendo observado que a média do país elevou-se apenas para $14,6 \%$.

A Meta 12 do novo Plano Nacional de Educação, PNE (2014-2024), Projeto de Lei n. 8.035/2010, aprovado após três anos de discussão, propõe elevar a taxa bruta $^{2}$ de matrícula na educação superior para 50\%, e a taxa líquida ${ }^{3}$ para $33 \%$, da população de 18 a 24 anos, até o ano de 2024. Isso significa mais que dobrar os índices verificados no fim da última década, que se for atingido, representará avanço na busca da minimização da seletividade no acesso à educação superior.

A despeito de críticas às políticas executadas pelos governos, há que se considerar que o Estado brasileiro tem empreendido esforços no sentido de efetivar o direito à educação, declarado em seus arcabouços legais. Para tanto, desde a década de 1990, um conjunto de políticas e programas governamentais vêm sendo implementados. O Exame Nacional do Ensino Médio - Enem, objeto do presente estudo, surge nesse contexto. Foi regulamentado pela Portaria n. 438 , de 28 de maio de 1998, do Ministério da Educação - MEC, no governo do então presidente Fernando Henrique Cardoso (FHC), com o objetivo inicial de avaliar, anualmente, o desempenho dos estudantes do ensino médio, e subsidiar o MEC na elaboração de políticas públicas e pesquisas educacionais.

Em 2009, a Secretaria de Educação Superior do Ministério da Educação SESu apresentou à Associação Nacional dos Dirigentes das Instituições Federais de Ensino Superior - ANDIFES, proposta de reformulação do exame, baseada nos

\footnotetext{
${ }^{2}$ A taxa bruta de matrículas na educação superior corresponde à relação entre o número de matriculados (independentemente da idade) com o número de pessoas na faixa etária considerada.

${ }^{3}$ A taxa líquida de matrícula na educação superior corresponde à relação entre o número de pessoas de uma dada faixa etária (em geral, entre 18 e 24 anos) matriculadas no Ensino Superior e o total da população da faixa etária considerada.
} 
pressupostos de "democratização das oportunidades de concorrência às vagas federais de ensino superior", por meio da qual o participante concorreria nacionalmente às vagas de instituições de educação superior públicas, com a aplicação simultânea das provas em todo o país. A proposta foi aceita e o Enem passou por reformulações, adquirindo maior dimensão e diversificação de seus usos, agregando aos seus objetivos iniciais a democratização do acesso à educação superior pública, sobretudo para pessoas oriundas de classes menos favorecidas economicamente.

Para operacionalização da referida proposta, o MEC, por meio da Portaria Normativa n. 02, de 26 de janeiro de 2010, institucionalizou o Sistema Único de Seleção Unificada - SiSU. Trata-se de recurso eletrônico, que tem o objetivo de gerenciar as vagas disponibilizadas nacionalmente pelas Instituições Federais de Ensino Superior - IFES aderentes ao Enem. Por intermédio desse Sistema, os participantes do exame passaram a ter oportunidade de concorrer a vagas em qualquer localidade do território nacional, sem o ônus do deslocamento para a realização das provas.

Após sua reformulação e vinculação ao SiSU, o Enem ganhou notoriedade, constituindo-se em uma política pública de Estado, que tem perpassado diversos governos, acrescendo ao exame novas finalidades. Com a ampliação de seus usos, especialmente no que se refere à unificação das provas, o exame tem tido expressivo número de inscritos, alcançando, na edição 2015, 7.745 .843 de participantes. Figura como objeto de visibilidade pública e, semelhante a qualquer política de grande vulto, não passa incólume às críticas e divergências no meio acadêmico.

Andriola (2011), em seu artigo "Doze motivos favoráveis à adoção do Enem pelas Instituições Federais de Ensino Superior", menciona que o exame é um processo seletivo adaptado às exigências da "nova" sociedade, e considera que a unificação das provas propiciada pela criação do SiSU, promoveu significativa evolução no que se refere ao acesso à educação superior brasileira. Para esse autor, o Enem transformou-se em instrumento indutor de democratização, ao possibilitar maiores chances de acesso à educação superior, às pessoas oriundas de classes menos favorecidas economicamente, não raras vezes excluídas desse processo, pela impossibilidade financeira de arcarem com os custos de deslocamento para realização de provas fora de sua cidade. 
Outro aspecto positivo ressaltado diz respeito à ocorrência de uma forma de seleção mais qualificada. De acordo com o discurso oficial acerca do processo unificado, a ampliação do universo de candidatos tende a elevar o nível dos cursos, além de favorecer a variedade cultural, transformando as universidades mais concorridas em polos multiculturais, reunindo estudantes das diversas regiões do país. A troca de experiências e o contato com culturas variadas seriam um ponto a favor na formação geral dos novos universitários.

Para aqueles que criticam, o Enem é considerado um mecanismo de intensificação da exclusão social, em virtude de suas características seletiva e classificatória, que legitimam o princípio do mérito. Hey (2009), especialista em Políticas Públicas de Educação, considera que o Enem não muda a realidade educacional, que é marcada pela desigualdade de oportunidades. Observa que se os vestibulares são excludentes, a utilização do Enem não altera essa lógica.

Carneiro (2012) e Travitzki (2013) chamam a atenção para alguns efeitos do Enem sobre o ensino médio. Para o primeiro autor, o exame não contribui para identificar e resolver os problemas relacionados com as diferentes condições de "partida" dos indivíduos que a ele se submetem. Para Travitzki (2013), a forma de divulgação das notas do exame traz um "ranqueamento" entre as instituições de ensino, estimulando a competição e, por conseguinte, o sentimento de superioridade nas escolas já bem conceituadas - que, num círculo vicioso, continuam a ser bem avaliadas - e de frustração dos alunos nas escolas menos conceituadas que, em situação adversa, não conseguem reverter o quadro, mantendo-se em condição inferior.

Nesta mesma linha de pensamento, diferentemente do que afirma a publicidade oficial, Leher (2009) acredita que a unificação das provas em uma única data torna a concorrência ainda mais desigual, privilegiando os participantes de maior renda. Em decorrência disso, candidatos com melhores condições financeiras, ainda que não obtenham nota suficiente para ingresso nas instituições que desejam, poderão se deslocar e ocupar as vagas nas melhores instituições do país, restando para os domiciliados no estado, com menor poder aquisitivo, cursos fora de sua preferência ou de menor prestígio. Nessa argumentação, ainda que o candidato de origem modesta consiga arcar com os custos do deslocamento e ocupe vaga em uma instituição a quilômetros de distância de sua casa, tem grandes chances de não permanecer no curso até sua conclusão, uma vez que não tem a garantia de ser 
assistido por políticas de permanência da universidade (bolsa permanência, alojamento, restaurante, entre outras).

As políticas de permanência vêm se expandindo gradativamente ao longo da década. O MEC, por meio da ANDIFES, aprovou em 2010 o Plano Nacional de Assistência Estudantil - PNAES, que apresenta as diretrizes norteadoras para a definição de programas e projetos de ações, com vistas à permanência dos alunos nas universidades.

Entretanto, em que pese a relevância de ações desta natureza, estudos realizados mostram que no âmbito das instituições federais, a demanda pelos programas é maior que a oferta. Souza e Bittar (2013) em pesquisa intitulada "Política de educação superior e os programas de permanência nas universidades públicas", verificaram que as ações implementadas na maior parte das IFES, com vistas a garantir a permanência dos alunos, não têm suprido a demanda, o que contribui para a evasão discente.

Silveira e Medeiros (2012), no trabalho denominado "Assistência Estudantil nas universidades federais brasileiras: um estudo sobre as políticas de permanência nas instituições de ensino superior públicas" constatou que, apesar de em âmbito nacional existirem diversos programas e serviços de assistência estudantil, a questão da permanência é, ainda, um desafio para a educação superior, pois as políticas públicas implementadas ao longo dos anos têm apresentado resultados pouco significativos.

Assim, a nova dinâmica do Enem, consubstanciada principalmente na possibilidade de o participante cursar a universidade fora de seu domicílio, somente favoreceria os que possuem renda para se manter, já que, conforme os estudos citados, a maior parte das universidades públicas não dispõe de programas de assistência suficientes para o atendimento das demandas. O Enem, na condição de nova forma de acesso à educação superior, institucionalmente é apresentado como sendo uma resposta aos anseios da sociedade de diversificar o perfil de estudantes nas universidades públicas, e de superar um histórico cenário, no qual o conhecimento e a formação em nível superior não se efetivavam para parte significativa da população.

Tendo em vista a nova configuração no cenário do acesso à educação superior, estabelecida a partir da reformulação do Enem, a visibilidade que o exame alcançou e a falta de consenso em torno da factibilidade dos seus objetivos, este 
trabalho se propôs a responder os seguintes questionamentos: o Enem, a partir de sua reformulação ocorrida em 2009, tem contribuído para a democratização do acesso à educação superior na Universidade de Brasília? E complementarmente, de que forma as ações implementadas pela UnB têm favorecido a permanência dos seus alunos? Espera-se, com as respostas, contribuir nos debates acerca das políticas de acesso às instituições de ensino superior e fomentar outras pesquisas acerca do tema.

\section{Justificativa}

A aprovação da Lei de Diretrizes e Bases da Educação Nacional - LDB (Lei n. 9.394/1996) trouxe importantes alterações no contexto da educação superior brasileira e uma nova perspectiva no acesso a este nível de ensino, ao estabelecer o fim da obrigatoriedade do exame vestibular enquanto única forma de ingresso aos cursos de graduação, propiciando a ampliação dos mecanismos de acesso à educação superior (BRASIL, 1996). Não obstante o norteamento legal, inicialmente poucas foram as instituições, e em sua maioria privadas, que inovaram na diversificação das formas de ingresso. Ainda que alternativas ao vestibular tenham sido implementadas, estas foram colocadas em prática paralelamente ao vestibular tradicional.

Observa-se que no dispositivo legal da criação do Enem figura como objetivo original avaliar as competências e habilidades dos estudantes ao final da educação básica e, com isso, auxiliar na elaboração de políticas educacionais. Todavia, segundo Cunha (2003), desde a sua institucionalização, existiu a intencionalidade do Estado de torná-lo um processo de seleção unificada de acesso à educação superior. Ao discorrer sobre democratização e processos seletivos, o autor afirma:

\footnotetext{
A LDB-96 silenciou-se sobre os exames vestibulares obrigatórios para todos os cursos superiores. Desde 1911, ela foi a primeira lei que nada disse a respeito. Um silêncio eloquente, em tudo coincidente com o projeto ministerial de tornar o ENEM o principal mecanismo de seleção (CUNHA, 2003).
}

Em 2009, onze anos após a criação do exame, o Ministério da Educação MEC começou a colocar em prática o que antes era um projeto, quando apresenta à 
ANDIFES, proposta cuja principal premissa apoia-se na ideia de "unificação dos processos seletivos das IFES, a partir da vinculação do Enem ao SiSU" (MEC, 2009).

O documento reforçou a legitimidade do vestibular como instrumento necessário para a seleção dos estudantes mais "capazes" em prosseguir os estudos em cursos do ensino superior. A seguir, chama a atenção para o fato de que a forma descentralizada de aplicação das provas do vestibular favoreceria estudantes que possuíssem condições econômicas para realizá-las em outras cidades ou estados, e que a centralização do processo em exame unificado, aplicado simultaneamente em todo o território nacional, estabeleceria isonomia na concorrência e democratização das oportunidades de acesso às IFES.

O documento apresenta os dados da Pesquisa Nacional por Amostra de Domicílios (PNAD/IBGE/2008), revelando que, em 2007, no tocante aos alunos matriculados no primeiro ano da educação superior pública, apenas 0,04\% residiam a menos de um ano no estado onde estudavam, caracterizando, portanto, baixa mobilidade entre estudantes nas diferentes Unidades da Federação, especialmente se comparado à média registrada nos Estados Unidos, onde 19,2\% dos alunos matriculados na educação superior, em 2007, residiam fora do estado de origem. As ponderações apresentadas na proposta mostraram-se convincentes, e os reitores das 55 universidades federais brasileiras manifestaram apoio à iniciativa do MEC de substituir o tradicional vestibular pelo Enem. O novo formato do exame foi colocado em prática e, gradativamente, adotado como processo seletivo para ingresso nas IFES, após aprovação da proposta, normatizada pela Portaria MEC $n^{\circ}$ 807, de 18 de junho de 2010, que estabelece:

Art. 1ㅇ - Instituir o Exame Nacional do Ensino Médio - Enem como procedimento de avaliação cujo objetivo é aferir se o participante, ao final do ensino médio, demonstra domínio dos princípios científicos e tecnológicos que presidem a produção moderna e conhecimento das formas contemporâneas de linguagem.

Art. $2^{\circ}$ - Os resultados do Enem possibilitam:

I - a constituição de parâmetros para auto-avaliação do participante, com vistas à continuidade de sua formação e à sua inserção no mercado de trabalho;

II - a certificação no nível de conclusão do ensino médio, pelo sistema estadual e federal de ensino, de acordo com a legislação vigente;

III - a criação de referência nacional para o aperfeiçoamento dos currículos do ensino médio;

IV - o estabelecimento de critérios de participação e acesso do examinando a programas governamentais. 
O discurso oficial acerca do Enem e do SiSU destaca que a dinâmica de unificação das provas do exame é uma das principais ferramentas de democratização para o acesso à educação superior, sobretudo para aqueles indivíduos oriundos de classes menos abastadas. Entretanto, existem críticas e contestações a respeito da pretensa efetividade do exame enquanto instrumento de democratização.

Em uma busca pelo estado da arte sobre o tema, constatou-se que o Enem é objeto de estudo em diversos artigos, dissertações e teses acadêmicas. Os trabalhos de Gomes (2013) e Mazzonetto (2014) abordaram a influência do Enem sobre o ensino médio, propondo mudanças para a construção e reestruturação do currículo neste nível de ensino.

Fernandes (2013), em pesquisa denominada "Avaliação de Programa Social de Acesso à Educação: O novo Enem na Universidade de Lavras", investigou as repercussões administrativas e acadêmicas da implantação do Enem nessa universidade.

Silva e Luz (2013), em seu artigo "Seleção para ingresso na educação superior: adesão ao Enem e SiSU", discorreram sobre a trajetória do Enem e do $\mathrm{SiSU}$, destacando os principais atos que os normatizaram, bem como os debates e conflitos que os permeiam. Oliveira (2008) e Viggiano et al. (2013) analisaram a matriz de criação do exame, discutindo sua função como avaliação de larga escala.

Silva e Prestes (2009) pesquisaram de que forma as provas do Enem abordam as questões referentes à Ciência, Tecnologia, Sociedade e Ambiente. Ramalho e Núñez (2011) organizaram uma coletânea de trabalhos que versam sobre a dimensão conceitual do Enem.

$\mathrm{Na}$ obra "Acesso à Educação Superior: A utilização do Enem/SiSU na Universidade Federal do Recôncavo da Bahia", Santos (2014) investigou as alterações no perfil do alunado da UFRB em razão da adoção do SiSU. Os resultados da pesquisa apontaram dados positivos quanto à utilização do Enem/SiSU naquela instituição, evidenciando que a intenção democratizante desse novo modelo de processo seletivo atingiu o objetivo pretendido no âmbito da UFRB. Entretanto, o pesquisador ressalta que, em sua pesquisa, propôs analisar os efeitos do processo de democratização apenas no que se refere ao ingresso dos alunos na instituição, não contemplando outras questões, como a migração e a permanência 
dos mesmos nas instituições, deixando tais aspectos a serem estudados em outro momento.

Embora as citadas pesquisas tenham realizado importantes abordagens em torno da implantação e reformulação do Enem, com exceção da pesquisas de Santos (2014), estas não focaram na verificação das mudanças ocorridas no perfil do alunado das universidades, após a utilização do Enem/SiSU. No âmbito da Universidade de Brasília (UnB), não foram encontrados trabalhos desta natureza, o que pode ser atribuído à recenticidade da institucionalização do SiSU e sua vinculação ao Enem, tornando o tema objeto passível de aprofundamento.

$\mathrm{Na}$ UnB, o Enem foi adotado como forma de acesso para as vagas remanescentes do vestibular e do PAS entre os anos de 2011 a 2013. A partir do primeiro semestre de 2014 , passou-se a destinar $50 \%$ das vagas do primeiro semestre letivo de cada ano para selecionados mediante SiSU, sendo a outra metade ocupada por alunos ingressantes pelo PAS. O tradicional vestibular é, atualmente, utilizado apenas para seleção no segundo semestre letivo.

O interesse pessoal pelo assunto é fruto da vivência na condição de servidora da UnB, lotada durante 15 anos na Secretaria de Assuntos Acadêmicos - SAA, acompanhando, diariamente, os desafios enfrentados pelos distintos segmentos da comunidade acadêmica (docentes, discentes e técnico-administrativos) frente ao processo de mudanças ocorridas na instituição, em razão de sua gradativa adesão ao exame. Além disso, justifica-se pela centralidade que o Enem vem assumindo no cenário das políticas públicas relacionadas à educação básica e superior, e por julgar relevante investigar se a democratização do acesso à educação superior atribuída ao exame vem de fato se concretizando na Universidade de Brasília. 


\section{Objetivo Geral}

Verificar se o Enem, a partir da sua reformulação ocorrida em 2009, tem contribuído para a democratização do acesso à educação superior na Universidade de Brasília, bem como identificar de que forma as ações implementadas pela UnB têm favorecido a permanência dos seus alunos.

Para tanto, foram definidos os seguintes objetivos específicos:

1- Traçar o perfil regional e socioeconômico dos alunos ingressantes mediante vestibular, no semestre 2013/2, e via Enem, no ano de 2014, nos cursos de Direito, Engenharia (Civil, Elétrica, Florestal e Mecânica), História, Matemática, Medicina e Pedagogia da UnB.

2- Investigar se houve alteração no perfil regional e socioeconômico dos alunos ingressantes por meio do Enem, no 2014/1, em relação aos ingressantes mediante Vestibular, no semestre 2013/2, nos cursos de Direito, Engenharia (Civil, Elétrica, Florestal e Mecânica), História, Matemática, Medicina e Pedagogia da UnB.

3- Verificar a percepção dos alunos quanto a importância das políticas de permanência para sua manutenção na UnB.

4- Analisar a percepção dos alunos atendidos por políticas de permanência na UnB, quanto à necessidade de alteração nessas políticas e/ou implantação de novas ações.

5- Apresentar sugestão de Proposta de curso, sob a forma de Produto Técnico. 


\section{CAPÍTULO 1}

\section{EVOLUÇÃO HISTÓRICA E DEMOCRATIZAÇÃO DO ACESSO À EDUCAÇÃO SUPERIOR BRASILEIRA}

Este capítulo é dividido em duas partes: a primeira aborda os aspectos históricos da evolução da educação superior no Brasil, desde o período colonial até o século XXI, contemplando as principais políticas públicas de acesso à educação superior, adotadas pelos governos Fernando Henrique Cardoso - FHC e Luiz Inácio Lula da Silva - Lula. Na segunda parte, são apresentadas as diversas concepções acerca do termo democratização, a forma que deve ocorrer a ampliação do acesso e os posicionamentos sobre qual esfera (pública ou privada) é a mais adequada para o aumento de vagas na educação superior.

\subsection{Educação superior no Brasil, do período colonial até a década de $\mathbf{1 9 3 0}$}

O Brasil, se comparado aos outros países da América Latina, tem história singular no que refere ao acesso à educação superior. Os espanhóis, quando colonizaram países da América, fundaram as universidades. Já no Brasil Colônia, havia desinteresse da Coroa portuguesa nessa direção.

Os portugueses acreditavam que a criação de escolas superiores levaria à diminuição da dependência colonial da metrópole, além de demandarem recursos financeiros considerados desnecessários para os fins comerciais. Esse quadro fazia com que a elite brasileira buscasse para seus filhos, formação superior em Portugal, sobretudo na Universidade de Coimbra. As primeiras escolas de ensino superior no Brasil surgiram no Rio de Janeiro e na Bahia, em 1808, e contemplavam a formação voltada à burocracia estatal e dirigente, além dos cursos de Teologia. Somente após 1822, é que surgiram cursos de Direito e Engenharia.

Até a proclamação da república, em 1889, o ensino superior desenvolveu-se lentamente, e visava assegurar diplomas profissionais que garantissem a ocupação de postos privilegiados, além de prestígio social (MARTINS, 2002).

O período entre 1891 e 1910 foi marcado pela criação de diversas escolas superiores no país, onde o acesso era automático, sem a necessidade de exames. A partir de 1911, a demanda por educação superior passou a ser maior do que o 
número de vagas ofertadas, e por meio da Reforma Rivadávia Correa, instituída pelo Decreto 8.659, de 1911, foram criados os exames de admissão, que com a Reforma Carlos Maximiliano - Decreto n. 11.530, de 18 de março de 1915, passaram a ser denominados de vestibular (MARTINS, 2002).

Mostra-se evidente o caráter seletivo e discriminatório dos vestibulares quando, por meio da Reforma Rocha Vaz, instituída pelo Decreto n. 16.782 - A, de 13 de janeiro de 1925, estabeleceu-se a relação entre número de candidatos por curso e a disponibilidade de vagas, sendo os aprovados no processo de seleção matriculados conforme a ordem de classificação. Nesse sentido, o vestibular, já a partir de sua criação, cumpre o papel de limitador de acesso à educação superior, que desde sua gênese, é caracterizada como elitista e excludente, a começar pela forma de seleção para o ingresso nas IES.

De acordo com Romanelli (2005), na década de 1930, com a ascensão de Getúlio Vargas à Presidência da República, foi publicado um conjunto de medidas sob forma de decretos, que constituíram a chamada Reforma Francisco Campos, dentre os quais, destaca-se o Decreto n. 19.851, de 11 de abril 1931, que entre outras medidas, regulamentou a organização do sistema universitário brasileiro e da educação superior ministrada em institutos isolados, e concedeu às instituições de ensino superior a prerrogativa de realizar seus próprios exames de acesso.

Outro importante arcabouço jurídico da referida Reforma é o decreto de n. 19.852, de 11 de abril de 1931, que dispôs sobre a organização da Universidade do Rio de Janeiro. Em seu parágrafo único, artigo 41, no que se refere ao exame vestibular, traz o seguinte teor: "Enquanto for exigido exame vestibular, versará este sobre as seguintes disciplinas [...]". No uso do termo "enquanto", depreende-se que, já àquela época, existia a concepção do vestibular enquanto instrumento temporário, e a intencionalidade da adoção de formas alternativas de acesso à educação superior.

O referido decreto mostra-se atual, uma vez que, embora durante quase um século o vestibular tenha mantido caráter hegemônico, sendo o único instrumento de acesso a cursos superiores, na história recente vem gradativamente sendo substituído pelo Enem. 


\subsection{Educação superior no Brasil nas décadas de 1940 a 1980}

No período pós-guerra, de 1945 até a instauração do Regime Militar em 1964, o ensino superior continuou se expandindo de forma lenta. Nesses 15 anos, o número de alunos matriculados passou de 41.000 para 95.000 (DURHAM, 2002).

$\mathrm{Na}$ década de 1960, conhecida como a década do desenvolvimento industrial, houve aumento da migração campo-cidade para atender a demanda por mão-deobra, fenômeno que levou à necessidade de qualificação dos trabalhadores e, em decorrência disso, aumento do número de matrículas no ensino médio e da procura pela educação superior. Neste período, também foi proposta pelo Banco Mundial aos países periféricos, a teoria do capital humano, apresentando a educação como elemento econômico, por meio do qual se efetivaria a equalização social, econômica e política entre indivíduos e classes.

Tal teoria preconizou que, em longo prazo, com a consolidação da economia, ocorreria um processo de redistribuição, assegurado por níveis mínimos de desemprego, com consequente aumento de produtividade e elevação da renda das pessoas menos favorecidas. No que se refere às relações internacionais, a teoria do capital humano serviu para ocultar as relações de poder, por meio da ideia de que o subdesenvolvimento dos países periféricos poderia ser superado pela modernização dos fatores de produção, atribuindo aos recursos humanos papel de destaque, e à educação a função de instrumento ideológico de desenvolvimento econômico.

Esta nova visão, segundo Oliveira (2008), procura trazer para a educação a racionalidade empresarial, com seus critérios de custo-benefício, eficiência e produtividade. A educação torna-se um investimento que, sendo bem planejado e gerenciado sistematicamente, pode ser frutífero para o "desenvolvimento do país".

Embora o sistema de ensino superior estivesse sendo ampliado gradualmente, a oferta de vagas em estabelecimentos públicos e privados era inferior à demanda. Segundo Cunha (1996), em 1960 existiam 28.728 candidatos que protagonizaram a "crise dos excedentes", uma vez que foram aprovados nos exames vestibulares para as universidades públicas, mas não foram admitidos por falta de vagas. O vestibular tornou-se um problema complexo, já que passou a ser um exame que privilegiava uma minoria, que acumulava ao longo de sua vida, condições de aprovação. Nessa 
época, a insuficiência na oferta de vagas era denunciada publicamente pelo movimento estudantil, representado pela UNE.

O fim dos anos 60 foi marcado por um processo de mudança radical na educação superior no Brasil. Em 1968, o governo militar implementou a chamada Reforma da Educação Superior (Lei n. 5.540/68), promovendo importantes alterações nesse sistema educacional, destacando-se a substituição das cátedras vitalícias pelo sistema departamental, o ciclo básico, o sistema de créditos e a matrícula por disciplina, bem como a carreira do magistério e a pós-graduação.

Entre as medidas propostas pela Reforma, com o objetivo de resolver 0 problema dos excedentes, foi instituído, em 1970, o vestibular unificado e classificatório (MARTINS, 2009). Os exames passaram a acontecer nas mesmas datas em todas as instituições, classificando os candidatos aos cursos superiores no limite das vagas fixadas por estabelecimento de ensino. Desse modo, foi possível minimizar o problema dos excedentes (MARTINS, 2009), contudo, sem significar que a demanda tenha sido atendida em sua totalidade.

Neste período, a universidade pública deixa de ser referência privilegiada de organização do ensino superior, proliferando as instituições privadas de educação, impulsionadas por forte demanda, pela escassez de recursos financeiros na esfera pública, e pela possibilidade de elevado lucro para a iniciativa privada, que passou a dominar o cenário educacional superior, conforme pode ser verificado no Quadro 1.1.

Quadro 1.1 - Evolução do número de matrículas no ensino superior - instituições públicas e privadas (1945-2013).

\begin{tabular}{|lrcrcr|}
\hline \multirow{2}{*}{ Década } & \multicolumn{2}{c}{ Público } & \multicolumn{2}{c|}{ Privado } & \multirow{2}{*}{ Total } \\
\cline { 2 - 5 } & Número & Porcentagem & Número & Porcentagem & \\
\hline 1945 & 21.307 & 51,6 & 19.968 & 48,4 & 41.275 \\
1960 & 59.624 & 58,6 & 42.067 & 41,4 & 101.691 \\
1970 & 210.613 & 49,5 & 214.865 & 50,5 & 425.478 \\
1980 & 492.232 & 35,7 & 885.054 & 64,3 & 1.377 .286 \\
1990 & 578.625 & 37,6 & 961.455 & 62,4 & 1.540 .080 \\
2000 & 887.026 & 33,0 & 1.807 .219 & 67,0 & 2.694 .245 \\
2010 & 1.461 .696 & 26,8 & 3.987 .424 & 73,1 & 5.449 .120 \\
2013 & 1.932 .527 & 26,5 & 5.373 .450 & 73,5 & 7.305 .977 \\
\hline
\end{tabular}

Fonte: base de dados do INEP (2014) 
Em 1960, o setor privado absorvia 41,4\% das matrículas e, no início dos anos 80 , respondia por $64 \%$. O número de matrículas no ensino superior passou de 101.691 para 1.377.286, sendo, em números absolutos, os anos de 1970 e 1980 os que apresentaram maiores taxas de crescimento. Entre 1968 e 1971, foram criadas 17 novas universidades públicas (nove federais, seis estaduais e duas municipais), e entre 1968 e 1975, dez universidades privadas.

Em 1980, já se tinha um total de 889 instituições de ensino superior. Dessas, 200 eram públicas (45 universidades, uma federação de escolas integradas e 154 estabelecimentos isolados) e 689 entidades privadas (20 universidades, 19 federações integradas e 643 estabelecimentos isolados) (INEP, 2014).

Observa-se que o crescimento da taxa de matrícula nas décadas de 1970 e 1980 ocorreu, especialmente, na iniciativa privada e no turno noturno, com o interesse de atender a parcela de jovens já inseridos no mercado de trabalho e que, de outra forma, não poderia acessar ao ensino superior.

Cabe ressaltar que o nível de exigência, tanto para acesso quanto para a conclusão desses cursos, era menor, o que contribuiu para o crescimento de suas matrículas. Cunha (1975) identifica o caráter contraditório do papel do Estado ao atendimento à demanda pela educação superior, quando afirma que:

[...] ela foi atendida tanto pelo Estado quanto pelo setor privado, com o
benefício deste e, talvez, para o alívio daquele [...] é possível que o
Estado tenha sido 'benevolente' para com as escolas particulares de baixa
qualidade devido ao 'alívio' que elas traziam para pressão da demanda
que incidia sempre sobre ele. Esse crescimento da demanda de ensino
superior atraiu capitais aplicados no ensino médio, em situação de taxas
decrescentes de lucro, devido à própria expansão da oferta de ensino
público nesse nível. Foi por isso que os colégios privados se
transformaram em faculdades (CUNHA, 1975).

Com o fim do período do governo militar, em 1985, esperava-se a retomada da presença do poder público na ampliação do alcance social da educação superior. Entretanto, isto não ocorreu. Os governos subsequentes restringiram os recursos financeiros para a esfera pública e fortaleceram, ano após ano, a expansão da educação superior privada, já então predominante, conforme veremos a seguir. 


\subsection{Educação superior durante as décadas de 1990 a 2000}

As ações governamentais implementadas no âmbito da educação superior nas duas últimas décadas promoveram expressiva expansão no número de instituições de ensino. Os governos FHC (1995 a 1998 e 1999 a 2002) e Lula (2003 a 2006 e 2007 a 2010), embora com ideologias políticas divergentes, mantiveram características semelhantes na configuração da educação superior, entre elas, o predomínio do segmento privado, conforme pode-se observar no Quadro 1.2, que apresenta o número de instituições de educação superior, no início e final de cada mandato dos governos FHC e Lula, bem como no primeiro mandato do governo Dilma Roussef.

Quadro 1.2 - Evolução do número de instituições de ensino superior privadas e públicas (1995 2013).

\begin{tabular}{|lrcc|}
\hline Ano & № total de IES & № de IES Privadas & №de IES Públicas \\
\hline 1995 & 894 & $684(76,5 \%)$ & $210(23,5 \%)$ \\
1998 & 973 & $764(78,5 \%)$ & $209(21,5 \%)$ \\
1999 & 1.097 & $905(82,5 \%)$ & $192(17,5 \%)$ \\
2002 & 1.637 & $1.442(88,0 \%)$ & $195(11,9 \%)$ \\
2003 & 1.859 & $1.652(88,8 \%)$ & $207(11,1 \%)$ \\
2006 & 2.270 & $2.022(89,0 \%)$ & $248(10,9 \%)$ \\
2007 & 2.281 & $2.032(89,0 \%)$ & $249(10,9 \%)$ \\
2010 & 2.378 & $2.100(88,3 \%)$ & $278(11,7 \%)$ \\
2013 & 2.391 & $2.090(87,4 \%)$ & $301(12,5 \%)$ \\
\hline
\end{tabular}

Fonte: MEC/INEP (2014).

Conforme pode-se observar, em 1995, existia um total de 894 instituições de nível superior no Brasil, passando para 973 em 1998, o que corresponde a um crescimento de 3,2\%. Em 2002, último ano do governo FHC, este número passou para 1637. De 1995 para 2013, cresceu de 894 para 2.391 instituições, sendo 301 públicas e 2.090 privadas, o que corresponde a um percentual de $12,5 \%$ na esfera pública contra $87,4 \%$ na esfera privada. O aumento no número de instituições privadas com relação às públicas deveu-se, segundo Martins (2009), entre outros fatores, à adoção, por parte dos governos, de uma série de mecanismos, entre os quais se destacam a liberalização dos serviços educacionais, as isenções tributárias e da contribuição previdenciária para entidades filantrópicas, as bolsas de estudo para alunos carentes, via programa de Crédito Educativo, criado em 1976 e 
denominado Fundo de Financiamento Estudantil (FIES) ${ }^{4}$ em 1992, empréstimos financeiros a juros baixos por instituições bancárias oficiais, a exemplo do BNDES, e o Programa Universidade para Todos (ProUni), institucionalizado em 2005.

1.3.1 Expansão da educação superior no governo Fernando Henrique Cardoso e a influência dos Organismos Internacionais

O programa político adotado pelo governo Fernando Henrique Cardoso (1995-1998 e 1999-2002) teve como base a modernização administrativa, associada aos princípios neoliberais, dando nova roupagem à visão eficientista e produtivista adotada a partir de 1960. A educação superior não escapou das implicações desta reordenação, e a partir de críticas do governo à ineficiência da universidade pública e de sua inadequação ao mercado de trabalho, apontou-se a necessidade de reformas, no sentido de dar racionalidade e eficiência a este nível de ensino.

Novos conceitos foram introduzidos à agenda de reformas: avaliação, autonomia universitária, diversificação, diferenciação, flexibilização e privatização. Cunha (2003) afirma que as ações norteadoras das reformas educacionais nessa década basearam-se na máxima neoliberal com a participação mínima do Estado, se afastando da concepção da educação enquanto bem público e direito de cidadania.

De acordo com Santos (2011), as universidades são pressionadas a produzir conhecimento em função de ganhos de produtividade e de competitividade, transformando a educação superior em bem transacionável no mercado, isto é, em bem privado ou privatizável. A posição no mercado passa a ser crucial, e nos processos mais avançados, é a própria universidade que se transforma em marca.

A política educacional brasileira passou a ser orientada pelas proposições extraídas da Conferência Mundial de Educação para Todos, ocorrida em Jomtien, na Tailândia, em março de 1990, quando a Organização das Nações Unidas para a Educação, a Ciência e a Cultura - UNESCO, o Programa das Nações Unidas para o Desenvolvimento - PNUD, o Banco Mundial e o Fundo das Nações Unidas para a Infância - UNICEF se colocam como regentes dos sistemas educacionais de

\footnotetext{
${ }^{4}$ O FIES é uma plataforma do Ministério da Educação destinado a financiar a graduação na educação superior, para estudantes matriculados em instituições que tenham avaliação positiva nos processos conduzidos por aquele ministério. Foi criado em substituição ao Programa de Crédito Educativo - Lei no 8436/1992.
} 
diversos países, incluindo-se o Brasil. Nesse período, formulou-se uma série de recomendações direcionadas aos gestores da política educacional, com ênfase no papel da educação para enfrentar os desafios de uma nova ordem econômica mundial.

Estudos realizados por Lima (2005), Sguissardi (2000), Leher (1998), Coraggio (2003) e Siqueira (2004), acerca das influências dos Organismos Internacionais sobre a reforma da educação brasileira nos anos 90, apontam que é nessa década que se aprofundam as relações entre estes e o governo brasileiro, o que impactou profundamente os rumos das políticas educacionais adotadas no país.

É necessário considerar que os Organismos Internacionais são diferenciados em termos de visão e propostas para a educação. Para Santos (2011), O Banco Mundial (BM), o Banco Interamericano de Desenvolvimento (BID) e a Organização para a Cooperação e Desenvolvimento Econômico (OCDE) são organizações econômicas, reguladas por interesses de mercado, apesar de se aterem às questões sociais e incentivarem o desenvolvimento econômico, especialmente dos países ou regiões em situação de maior vulnerabilidade econômica. Já a UNESCO e a Organização das Nações Unidas (ONU), atuam no campo das questões humanitárias, buscando soluções para problemas das nações, desenvolvimento e a paz mundial.

Segundo o teórico, embora com objetivos distintos, esses organismos multilaterais, por meio de diagnósticos ou indicações de experiências positivas, incentivaram um modelo de educação superior pautado na excelência, na competitividade e na utilização de indicadores quantitativos de desempenho, distanciando-se de uma formação acadêmica, crítica e autônoma, o que fez com que a educação fosse perdendo sua identidade como direito social e seu caráter eminentemente público, passando a ser concebida como mercadoria.

Sob a máxima da racionalização de recursos e pela necessidade de elevar os níveis de eficiência e de responsabilidade social, as IES públicas tomaram iniciativas para captação de recursos junto a empresas e clientes, com a venda de seus serviços por intermédio de cursos pagos, sobretudo de especialização, realização de parcerias entre as universidades públicas e empresas para consultorias e assessorias, implementação de cursos de extensão universitária, e criação de mestrados profissionalizantes (SGUISSARDI e SILVA JR, 2001). 
A nominação das universidades foi ampliada para universidades, centros universitários, faculdades integradas, institutos superiores ou escolas superiores. Outra medida importante foi a transformação de algumas entidades de serviços do Estado em Organizações Sociais. As IES ganharam relevância, enquanto formadoras de quadros qualificados para colocar o Brasil em condições competitivas com os países desenvolvidos. O eixo de interesse deslocou-se da ideia de instituições voltadas para a pesquisa, para instituições produtivas que atendessem aos interesses do capital, promovendo profundas mudanças que, ainda hoje, se mantêm na cultura institucional das universidades públicas brasileiras.

A expansão das IES privadas em detrimento das públicas, ocorrida no governo $\mathrm{FHC}$, provocou sérias críticas do meio acadêmico quanto à política educacional superior. Silva Júnior e Sguissardi (2001) indicam que a implantação de políticas públicas, seguindo orientações advindas de organismos internacionais, priorizou a simples expansão de vagas, sem levar em conta o fator qualidade.

Durham (2002) corrobora com o estudo acima, afirmando que a expansão do setor privado não foi acompanhada por uma avaliação do nível da qualidade. Complementa que, ao lado de alguns estabelecimentos com formação de qualidade, proliferaram escolões, ou pouco mais que fábricas de diplomas. O autor questiona:

\footnotetext{
Não estaria o processo de aceleração da oferta de vagas e de matrículas no ensino superior produzindo uma armadilha social, uma vez que teríamos um sistema diversificado, e ao mesmo tempo, diferenciado em termos de qualidade? (DURHAM, 2002).
}

Amaral (2009) realizou estudo para o Instituto Nacional de Pesquisas Educacionais Anísio Teixeira - INEP, e demonstrou que a expansão da rede privada proliferou até o ano de 2002, quando o crescimento da oferta de vagas foi mais acelerado que a demanda, reduzindo a relação candidato/vaga de 2,2 em 1998 para 1,6 em 2002. O esgotamento da expansão via iniciativa privada foi ocasionado pela incapacidade das famílias de arcar com o pagamento das mensalidades. $O$ fato fica evidente quando se observa o percentual de vagas não preenchidas pelo vestibular nas instituições privadas. Enquanto em 1998, o percentual era de 20\%, em 2002, saltou para $37 \%$, demonstrando que a política de expansão da educação superior, que privilegiava a democratização pela via esfera privada, encontrou como principal entrave a natureza dessas vagas e/ou a incapacidade econômica dos candidatos em 
ocupá-las (CORBUCCI, 2002). Em consequência, o FIES, direcionado aos alunos de baixa renda, deixou de ser uma possibilidade interessante, frente ao baixo crescimento econômico e elevado nível de desemprego e altas taxas de juros vivenciados durante o governo $\mathrm{FHC}$.

No segundo mandato de FHC, verificou-se o aprofundamento da opção política, estabelecida desde o regime militar, de estímulo à iniciativa privada na expansão de vagas, inclusive, segundo Carvalho (2012), exaltando-se, em várias ocasiões, a eficiência e a produtividade dessas instituições. Defendeu-se que não havia necessidade de criação de novas universidades federais, pois a expansão deveria ocorrer pelo aumento do número de alunos em sala de aula e pela oferta de cursos noturnos.

\subsubsection{Expansão da educação superior no governo Luiz Inácio Lula da Silva}

A eleição presidencial de 2002 despertou expectativas de mudanças. Pela primeira vez no Brasil, um presidente originava-se das camadas populares. Acreditava-se que com o novo governo, os rumos das políticas sociais caminhariam de forma a diminuir as desigualdades provenientes do capitalismo excludente. Lula assume a Presidência da República, em 2003, e ao contrário do esperado, percebeu-se o seu alinhamento "[...] com a parcela da sociedade civil que arrebanha os dotes industriais e comerciais, ou seja, a sociedade civil empresarial organizada" (LIMA, 2011).

Embora tenham se apresentado com alguns ajustes, as políticas sociais do novo governo acomodaram-se aos princípios gerenciais das leis de mercado. Podese afirmar que, em seu primeiro mandato (2003-2006), houve continuidade e ampliação das políticas estabelecidas para a educação superior no governo anterior, priorizando-se como papel fundamental das universidades, o retorno econômico, ao incentivar a criação de parcerias público-privadas, inovação tecnológica, venda de serviços, e ao conferir centralidade aos sistemas de avaliação e regulação.

Leher (2009) acentua que, no governo Lula, a política de educação superior continuou seguindo as orientações das agendas do Banco Mundial (BM), do Banco Interamericano (BID) e da Comissão Econômica para América Latina e o Caribe (CEPAL), de modo a conformar a universidade pública em um setor mercantil 
balizado pelos valores neoliberais e pelas orientações dos organismos internacionais:

\begin{abstract}
Analisando as medidas implementadas até o momento, é possível constatar que as políticas dos Organismos Internacionais seguem guiando os cérebros do governo Lula. Com efeito, a modernização do MEC coincide no fundamental com as agendas do Banco Mundial, do BID e da Cepal para as instituições de educação superior públicas, racionalizando o acesso não por medidas universais, mas por cotas; criando programas de estímulo à docência por meio de gratificações por produtividade; realizando avaliação padronizada da "qualidade" (ENADE), inspirada na teoria do capital humano vinculado com os planos de desenvolvimento institucional, avaliação (Sinaes) e financiamento (financiamento por meio de contratos); direcionando o "mercado educativo" da instituição para o âmbito regional, e realizando associação linear e estreita entre eficiência acadêmica e pragmatismo universitário. o Banco difunde posicionamento ideológico de modo a conformar a universidade pública em setor mercantil balizado pelos valores neoliberais. (LEHER, 2009).
\end{abstract}

Almeida (2012) destaca que as políticas para expansão da educação superior fizeram parte da agenda dos governos de FHC e Lula, os quais enfrentaram o problema de forma distinta. FHC optou pela expansão do acesso por meio das IES privadas, no fomento à competitividade entre as IES, mediante o processo de avaliação, da suspensão nos processos de contratação de professores e funcionários, e da diminuição significativa do financiamento das universidades federais. O teórico complementa que no governo Lula predomina uma política neoliberal popular, que mantém parte das características acima indicadas, diferenciando-se por realizar a intervenção estatal [...], que não visava combater os preceitos neoliberais, mas fazê-los funcionar utilizando-se dos aparatos estatais.

Segundo Catani (2002), subjacente a essa ideia, encontra-se a noção do público não estatal - espaço entre o Estado e o mercado - também chamado de terceiro setor. Este seria regido pela lógica empresarial, com parte do financiamento público e outra parte privado, adquirido mediante contribuições ou venda de serviços ao mercado.

Buscando promover a expansão do acesso à educação superior, surgiram no governo Lula, novas formas de interpenetração entre o público e o privado de modo que o Estado atuou como financiador de políticas e programas que buscaram apoiar tanto as instituições privadas quanto os alunos (PINHEIRO,1996). A fim de caracterizar essa relação pode-se citar a institucionalização do Programa Universidade para Todos (ProUni) e o aprimoramento do Fundo de Financiamento 
Estudantil (FIES), duas políticas que se constituíram em mecanismos para expandir o acesso a esse nível de educação, bem como para atender aos interesses do mercado.

O ProUni foi institucionalizado pelo MEC em 2005, para resolver tanto a questão do aumento de vagas ociosas na esfera privada, quanto a procura por parte das camadas de baixa renda pelo acesso à educação superior. Sob o manto do discurso de justiça social, direciona-se aos estudantes socioeconomicamente vulneráveis, originários do ensino médio público ou do ensino privado, neste caso, na condição de bolsistas. Além disso, o Programa destina parte de seus recursos aos negros, indígenas e portadores de deficiência e prioriza professores da rede pública de Educação Básica, no processo de concessão de bolsas de estudo, em troca de isenção fiscal de tributos federais. Dito de outra forma, seria uma maneira de destinação de dinheiro público ao ensino privado, o que Sguissardi (2006) classifica de desvio do propósito da oferta de ensino de qualidade para todos, pois, para o teórico, as instituições privadas, embora priorizem as atividades de ensino, são consideradas de baixa qualidade, se comparadas às públicas.

Desde a sua criação, em 2005, o programa já concedeu mais de 1,7 milhão de bolsas. No primeiro semestre de 2015, foram disponibilizadas 213.113 bolsas, sendo 135.616 integrais e 77.497 parciais. Os números são expressivos, sugerindo uma política pública de resultados positivos. Entretanto, o que se observa neste Programa é a continuidade das políticas privatistas, onde o governo se abstém da sua responsabilidade, quanto à oferta de educação pública, gratuita e de qualidade, e transfere recursos públicos para o fortalecimento do setor privado, empresariamento e mercantilização da educação superior.

O FIES, criado em 1999 no governo FHC, em substituição ao Programa de Crédito Educativo - PCE/CREDUC foi aprimorado em 2005, no governo Lula. Tratase de Programa destinado a financiar cursos de graduação para estudantes de baixa renda, que, tenham participado do Enem no ano anterior e estejam matriculados em instituições privadas de educação superior, reconhecidas pelo MEC. O aluno tem acesso a financiamento de até $100 \%$ de seu curso, o qual poderá ser pago num prazo até três vezes superior à duração da graduação.

O ProUni e o FIES, no ano de 2013, contribuíram para a expansão da educação superior privada, detentora, naquele ano, de quase $74 \%$ do total de vagas, 
conforme quadro 1.1, da seção anterior. Deve ser considerado, que mesmo em proporções bastante desiguais, ao estabelecer a política educacional, o governo Lula manteve o crescimento do segmento privado, em atendimento às pressões do mercado, mas, ao mesmo tempo, favoreceu a expansão da educação superior pública, com o incremento da interiorização dos campi das universidades federais. $O$ número de municípios atendidos por universidades públicas passou de 114 em 2003, para 289 até o final de 2014, favorecido pelo Programa de Apoio a Planos de Reestruturação e Expansão das Universidades Federais (Reuni), instituído pelo Decreto n. 6.096, de 24 de abril de 2007, sendo esta uma das ações do Plano de Desenvolvimento da Educação (PDE), de 2001.

O principal objetivo deste Programa foi ampliar o acesso e a permanência na educação superior, com foco na camada da população historicamente alijada deste nível de ensino, atentando para a ampliação da oferta de cursos noturnos e combate à evasão. O Reuni foi adotado por todas as IFES e teve seu término em 2012. Recebeu críticas de parte do meio acadêmico, que o considerou revestido de viés ideológico e com insuficiente aporte de recursos, favorecendo a precarização das IFES e ensino de qualidade duvidosa. A avaliação do período de vigência desse Programa e de suas implicaçõeS é de relevância para compreensão do atual contexto da educação superior pública e merece ser foco de um estudo em particular.

Após o Reuni, o Projeto de Lei no. 73/99, que tramitava há 13 anos, foi aprovado em 29 de agosto de 2012, dando origem à Lei № 12.711 que prevê reserva de vagas nas universidades federais e nas instituições federais de ensino técnico de nível médio para estudantes egressos do ensino médio público. O dispositivo legal denominado Lei de Cotas busca a reparação de injustiças sociais, por meio da inclusão de segmentos minoritários da sociedade na educação superior. Institui a reserva de $50 \%$ do total de vagas da instituição, subdividindo-as da seguinte forma: metade para estudantes de escolas públicas com renda familiar bruta igual ou inferior a um salário mínimo e meio per capita e metade para estudantes de escolas públicas com renda familiar superior a um salário mínimo e meio. Em ambos os casos, também é levado em conta o percentual mínimo correspondente ao da soma de pretos, pardos e indígenas no estado, de acordo com o último censo demográfico do IBGE. 
Pelo texto da lei, são considerados cotistas todos os alunos que cursaram com aprovação, as três séries do ensino médio em escolas públicas ou Educação de Jovens e Adultos (EJA) ou tenham obtido certificado de conclusão do ensino médio pelo Enem.

Das 171.401 vagas disponíveis pelo SiSU no ano de 2014, 64.082 foram destinadas a estudantes que atendam aos requisitos da Lei de Cotas. E em 2015, das 205.514 vagas, 82.879 foram destinadas a este público.

Outra importante ação na esfera pública refere-se à reformulação do Enem e a diversificação de seus usos, agregando ao seu caráter avaliativo, a função de instrumento de seleção. O Enem passou a ocupar lugar de destaque na racionalização do ingresso à educação superior, seja pública ou privada, uma vez que $\mathrm{o}$ acesso à diversas oportunidades educacionais (vagas regulares nas IFES, ProUni, FIES, Programa Ciência sem Fronteiras, entre outros), é condicionado à participação no Exame.

Constata-se que o quadro atual de oportunizações de acesso á educação superior, não é o mesmo que em épocas passadas. Pode-se dizer que as políticas implementadas, independementemente de atenderem o alunado na esfera pública ou privada, perseguem o propósito de atingir maior equidade no acesso à educação superior, em consonância com uma tendência verificada em vários países nas últimas décadas.

Em que pesem os ganhos quantitativos de matriculas na educação superior, ao tratar desta questão, a sociologia da educação tem mostrado que as trajetórias malsucedidas, comumente são atribuídas à responsabilidade total do indivíduo, e não produto das condições sociais objetivas nas quais estão inseridas esses sujeitos. Em razão disto, há uma competição injusta e desigual: poucos alunos oriundos da rede pública ingressam em universidades públicas, restando-lhes como opção as instituições privadas de ensino, algumas consideradas de qualidade duvidosa e com baixa produção em pesquisas. Esta constatação confirma a tendência de exclusão e a incapacidade do sistema público, de acolher as camadas menos favorecidas da população.

Estudo realizado por Pinto (2004) a partir dos indicadores produzidos pelo INEP, IBGE e Unesco sobre a situação do acesso à educação superior no país nos últimos quarenta anos, estima que alunos vindos de famílias de maior poder aquisitivo frequentariam as IES públicas, ao passo que os alunos mais pobres iriam 
para as IES privadas. Este quadro não se alterou, pois recente pesquisa coordenada por Andrade e colaboradores (2012) da Unicamp, apresenta uma conclusão estarrecedora: mais de $80 \%$ de jovens entre 18 e 24 anos ainda não têm acesso à educação superior, e que $38 \%$ dos matriculados em educação superior não dominam habilidades básicas de leitura e escrita, conforme o Indicador de Alfabetismo Funcional (INAF), divulgado pelo Instituto Paulo Montenegro (IPM) e pela ONG Ação Educativa. Este indicador reflete o expressivo crescimento de universidades de baixa qualidade. Entre os desafios propostos para a educação superior para os próximos anos, está a busca do equilíbrio entre o público e privado, tanto no crescimento das matrículas, quanto na questão da qualidade da educação ofertada. Para além do aumento de vagas, é necessário refletir sobre a forma como a desejada e propagada democratização vem se efetivando.

\subsection{Concepções acerca da democratização do acesso à educação superior}

Ao discorrer sobre as características e transformações da educação superior, Martin Trow (2005) desenvolveu um modelo teórico que divide o sistema de educação superior em três fases: sistema de elite, sistema de massa e sistema de acesso universal. Segundo o autor, o processo de transição de uma fase para outra pode ser analisado pelo tamanho do sistema, ou seja, pela ampliação de matrículas efetivadas dentro da faixa etária pertinente (jovens entre 18 a 24 anos).

Segundo Martin Trow (2005), levando-se em conta a taxa líquida, o sistema de ensino de elite é aquele que abarca até $15 \%$ da população em idade regular entre 18 e 24 anos na educação superior. O sistema de massa é aquele que atende entre 16 a 50\% dos indivíduos da referida faixa etária na educação superior, e o sistema universal, por sua vez, é aquele em que mais de $50 \%$ são atendidos no nível de ensino em questão.

Dados do Censo educacional brasileiro mostram que, no ano de 2001, apenas $12 \%$ da população de 18 a 24 anos cursava a educação superior. Neste cenário, foi aprovado pela Lei n. 10.172, de 09 de janeiro de 2001, o Plano Nacional de Educação - PNE (2001-2010), tendo como uma de suas medidas, massificar o acesso a esse nível de ensino. Buscava-se atingir o percentual de $30 \%$ de matrículas dentro do período estabelecido para a vigência do Plano. Em 2012, dois anos após o período estabelecido para sua execução, a meta não foi atingida, pois 
nesse ano, apenas o percentual de $14,6 \%$ dos jovens nesta faixa etária, encontravam-se matriculados na educação superior.

Em 2013, de acordo com o Censo da educação superior, 7.305.907 estudantes estavam matriculados nos cursos de graduação no Brasil (CENSUP, 2014). Este número, embora superior à população de muitos países, representa apenas $15,1 \%$ da taxa de escolarização líquida e $28,7 \%$ da taxa bruta. Baseado nas informações do censo, e considerando as dimensões estabelecidas por Trow (2005), pode-se depreender que o Brasil está apenas iniciando o processo de saída de um sistema de acesso de elite, necessitando, para consolidar um sistema de massa, atingir a taxa líquida de 33\%, conforme meta 12, do no novo PNE (2014-2024), com vigência até 2024. A concretização dessa meta revela-se desafiadora, pois ainda existe distanciamento entre o direito de acesso à educação superior e sua concretização, pois conforme afirma Bourdieu (1996), as desigualdades de acesso e de êxito escolar surgem nos níveis anteriores de ensino, acentuam-se no percurso de escolarização e tendem a refletir-se nas condições de acesso à educação superior.

Estudantes oriundos de classes menos favorecidas enfrentam diversas barreiras ao ingresso à educação superior, que os acompanham desde os níveis anteriores de ensino, via de regra, de má qualidade. Ao discorrer sobre a questão das desigualdades educacionais, Ciavatta (2008) afirma que o momento de seleção para ingresso na educação superior "é a face visível, a área de manobra de um sistema social injusto e elitizante, que promove a seletividade social por diferentes mecanismos". Muito antes do momento de seleção para ingresso nas universidades, ocorre a triagem social, uma seleção prévia, diretamente relacionada à educação que o indivíduo obteve anteriormente.

Segundo dados do IBGE (2014), em 2013, o número de crianças matriculadas na escola, na faixa etária entre quatro e cinco anos chegou a $81,2 \%$, o que significa crescimento de $3,1 \%$ em relação ao ano de 2012, quando este percentual era de $78,1 \%$. Nesse mesmo período, o percentual de crianças de seis aos quatorze anos de idade, chegou a 98,4\%. Quanto ao ensino médio, os números mostram que, em 2013, 15,8\% dos jovens na idade de 15 a 17 anos, público-alvo deste nível de ensino, estavam fora da escola. Dos $84,2 \%$ dos alunos matriculados, uma parte significativa frequentava turmas de ensino fundamental, portanto, em defasagem idade-série. Para Castro (2006), de certa forma, a maioridade legal aos 18 anos 
simboliza para muitos, sobretudo para aqueles menos favorecidos economicamente, independentemente da conclusão do ensino médio, o fim da vida escolar, o que faz com que muitos deles abandonem a escola. Para a autora, o equacionamento da questão passa pela revisão do currículo, pela integração com a educação profissional, e por uma política de diversificação do ensino médio.

As deficiências existentes no ensino fundamental e médio da rede pública fazem com que as classes sociais passem por um filtro, que traz como consequência a baixa representatividade das classes menos favorecidas na educação superior pública, sobretudo nos cursos mais concorridos. Chegar à educação superior continua não sendo algo natural para jovens oriundos de classes menos favorecidas, porque parte significativa deles possui baixo capital cultural. Bourdieu (1996) cunhou este termo para designar as vantagens culturais que os indivíduos ou famílias possuem, e que via-de-regra, os conduzem a um nível socioeducacional mais elevado.

Ao discorrer sobre a influência do capital cultural no percurso escolar do indivíduo, Bourdieu (1996) afirma que este é fator determinante no acesso ou não ao curso de graduação. Complementa que, raramente, esse cenário se altera, e quando ocorre, a pessoa é tida como referência para as demais. Uma criança que por todo o ensino fundamental e médio estudou em escola pública e, depois de muito esforço, alcança uma vaga em uma universidade pública, torna-se motivo de orgulho não só para a família, mas para o bairro e a comunidade, e se destaca como exemplo a ser seguido pelos demais.

Bourdieu (1996) contribuiu significativamente para as ciências humanas e sociais, ampliando o conceito de capital cultural, apresentando-o sob três estados: incorporado, objetivado e institucionalizado.

No estado incorporado, o capital cultural é uma propriedade agregada à pessoa, tornou-se um habitus e faz parte da sua história. Segundo o sociólogo, tem como principais elementos constitutivos os gostos, o domínio maior ou menor da língua culta e as informações a respeito do mundo. A aquisição desse tipo de capital é um trabalho do "sujeito" sobre si mesmo, o qual não pode ser transmitido instantaneamente por compra, venda, doação ou transmissão hereditária, diferentemente do dinheiro, do título de propriedade ou mesmo do título de nobreza. O capital cultural no seu estado incorporado constitui, assim, a herança familiar que atua de forma mais marcante na definição do futuro escolar dos descendentes, uma 
vez que as referências culturais, os conhecimentos considerados apropriados e legítimos, facilitam o aprendizado dos conteúdos e dos códigos escolares.

No estado objetivado, o capital cultural existe sob a forma de bens culturais, tais como esculturas, pinturas, livros, cinema, entre outros. Nesse estado, o capital cultural está ligado ao capital econômico, pois para possuir os bens econômicos na sua materialidade é necessário ter o capital econômico, o que se evidencia na compra de livros, por exemplo. No entanto, para apropriar-se simbolicamente desses bens é necessário possuir capital cultural no estado incorporado.

Já o capital cultural no estado institucionalizado está ligado à formação ou a diplomas adquiridos. O grau de investimento na carreira escolar está vinculado ao retorno provável que se pode obter com o título escolar, notadamente no mercado de trabalho. Nas palavras de Bourdieu (1996), o capital institucionalizado permite estabelecer taxas de convertibilidade entre o capital cultural e o capital econômico, garantindo valor monetário a determinado capital cultural. É relevante destacar que o diploma serve como base de comparação e o reconhecimento de determinado certificado escolar depende do prestígio da instituição onde ele foi conseguido. Podemos inferir, então, que o grau de investimento na carreira escolar está vinculado ao provável retorno que se pode obter pelo título escolar no mercado de trabalho.

Ao estudar o tema, Dubet (2003) chama atenção para o fato de que alunos originários de classes privilegiadas, geralmente mais bem munidas de capital cultural, ingressam em cursos considerados mais prestigiosos e rentáveis. O capital cultural dos pais, a postura de incentivo à leitura, o acompanhamento nas atividades escolares e extraescolares, são vantagens no acesso ao ensino superior.

Corroborando o pensamento de Bourdieu (1966), Dubet considera que o nível superior apenas reflete as desigualdades existentes na educação básica, de forma que o ingresso nos cursos superiores depende do desenvolvimento dos níveis de ensino antecedentes, principalmente do ensino médio. Sampaio et al. (2000), complementam que "é neste nível de ensino que se definem as possibilidades de ingresso dos jovens nos diferentes estabelecimentos de ensino superior no país".

Somente com maior atenção aos níveis anteriores de ensino, será possível ampliar-se o horizonte de expectativas e possibilidades dos concluintes do ensino médio público, para que o ingresso na educação superior se torne uma de suas alternativas futuras. É preciso também refletir sobre o real significado do conceito da 
expressão democratização, e descobrir qual educação nós queremos, para quem e para quê serve esta educação. Sem essas reflexões, a pretensão de democratizar a educação superior produzirá resultados inócuos.

Bourdieu e Passeron (1996) argumentam que o entendimento do termo democratização exige uma constante atenção epistemológica, pois o enfoque dado ao termo, expressa a forma com que cada sujeito ou grupo compreende a realidade política e social onde está inserido, além de seus variados e, algumas vezes, contraditórios interesses.

A palavra democratização deriva do termo democracia, cuja origem etnográfica vem do grego, demo que significa povo, e kracia, governo. Norberto Bobbio (1997), em sua obra "O futuro da democracia", ao fazer observações sobre o estado atual dos regimes democráticos, apresenta uma concepção de democracia liberal, em que a participação figura como elemento central. Afirma que só existe democracia quando são garantidos aos cidadãos, direitos fundamentais, como liberdade de pensamento, de religião, de imprensa, de reunião, acrescentando-se, a isso, a democracia representativa ou parlamentar, em que as leis são feitas por representantes eleitos pelos cidadãos a quem são reconhecidos os direitos políticos.

Coutinho (2011) vai além desta concepção. Considera que a democracia não pode ser reduzida ao direito do sufrágio universal, pois em seu conceito está implícito também o sentido de igualdade material, que significa o direito de todos se apropriarem dos bens criados. Já na visão de Silva (2006), a democracia é mais que uma forma de governo, referindo-se a uma prática social com participação efetiva dos membros de uma coletividade, no usufruto dos bens materiais, culturais, artísticos e educacionais produzidos.

Para Lukács (2008), sob o ponto de vista histórico, a democracia é uma força política concreta e inserida numa formação econômica particular, terreno em que ela nasce, realiza-se, problematiza-se, refaz-se e transforma-se. Em ensaio intitulado "Socialismo e Democratização", ao refletir sobre o conceito de democracia, Lukács considera mais adequado o uso do termo democratização. Esta concepção ampla de democracia, que ultrapassa o conceito formal de governo democrático, não se limita à garantia do direito formal expresso em Lei, mas envolve o acesso que, neste caso, significa o "alcance de coisa elevada ou longínqua” (FERREIRA, 2009).

Para Lefevbre (1979), não existe uma "verdadeira democracia", mas sim, uma constante "luta pela democracia", jamais completamente vitoriosa, porque, em 
virtude de suas contradições, a democracia pode sempre avançar e regredir. Portanto, trata-se de um processo e não de uma situação estática, uma construção dialética, pautada em momentos de afirmação, de negação e de superação de eventos ou ideias, permanentemente. Seguindo o pensamento marxista, o autor afirma que a democracia pode "tornar-se" democratização pela ação concreta do homem.

Ao entender a democratização como processo dinâmico da democracia, usufruto coletivo dos bens produzidos socialmente, e incluindo a educação superior como pertencente a este conjunto de bens, faz-se necessário diferenciar as diversas concepções em torno da democratização do acesso a educação superior, considerando tanto os avanços que ocorreram neste nível de ensino, decorrentes das políticas públicas colocadas em prática nas últimas décadas, quanto reconhecer seus limites, desafios e os diversos aspectos envolvidos na questão.

Podem-se distinguir três visões para a democratização. Na primeira visão, associa-se democratização do acesso a uma simples expansão de vagas. Dessa forma, os conceitos de ampliação e democratização são entendidos como sinônimos. Se mais pessoas tiverem acesso, haverá democratização. Ciavatta (2008) propõe que esta primeira visão é a base do princípio liberal da universalidade, no qual os níveis educacionais, inclusive o superior, estariam disponíveis a todos, independente da origem socioeconômica e da diferença de status ou de nascimento, condicionando-se apenas a questões de mérito individual. Essa ideia, que passou a ser discutida mais intensamente a partir da década de 1960, ganhou relevância com o aumento da demanda por vagas nas universidades do país, quando o tema democratização foi incorporado à agenda governamental.

Numa segunda perspectiva defendida por outros pesquisadores, a exemplo de Veloso (2011), a democratização do acesso é mais complexa e não se reduz a uma simples expansão da oferta de vagas. O teórico associa o termo democratização ao ingresso na educação superior, de camadas sociais menos privilegiadas economicamente. Ao discorrer sobre o tema, afirma que o conceito de democratização mais apropriado é o que envolve um aumento de vagas, associado à utilização de mecanismos de inclusão de minorias sociais na educação superior. Somente quando maior número de pessoas desfavorecidas economicamente ingressa na educação superior, pode-se falar em democratização. 
Uma terceira concepção do conceito vai mais além. Considera, tal como antes, que a democratização do acesso à educação superior não é uma mera ampliação das vagas. Defende o princípio de que a democratização requer que camadas sociais mais pobres tenham acesso à universidade. Porém, acrescenta que a democratização não se refere apenas a níveis sociais, devendo também levar em conta a raça. Nessa linha de pensamento, o acesso à universidade torna-se democrático quando aumenta o acesso das camadas não privilegiadas e, também, quando crescem as chances de ingresso de negros e indígenas (Nogueira, 2008). A política de cotas tem sua gênese nesta concepção.

Moehlecke (2004) também concebe a democratização partindo da expansão da oferta de vagas associada à utilização de mecanismos de inclusão de minorias sociais na educação superior. Coloca em xeque o mérito acadêmico, na forma como é tradicionalmente entendido. Para o teórico, o mérito deve ser medido pela capacidade dos estudantes em condições adversas superarem as dificuldades encontradas, por meio do esforço, mesmo que o resultado não seja igual ao dos estudantes que possuem condições mais favoráveis.

A esfera em que deve ocorrer o aumento de vagas é também aspecto polêmico quando se discute a questão da democratização da educação superior. Heringer (2011) defende que as vagas devem ser ampliadas nas instituições de ensino superior, sem levar em conta a esfera administrativa (pública ou privada), na qual ocorrerá tal crescimento. A combinação de ações voltadas para a expansão de vagas na educação superior, seja na esfera pública ou privada, promoveu importante avanço nas políticas públicas das últimas décadas, sendo instrumento indutor do avanço profissional dos indivíduos e elemento essencial à formação de quadros que colaborem para o desenvolvimento do país.

Existem autores que se posicionam a favor da ampliação de vagas nas IES públicas, e autores que defendem tal ampliação nas instituições privadas. Mancebo (2008) defende a expansão de vagas no setor público, argumentando que as IES públicas funcionam com a lógica de Estado, e não de mercado. Além disso, as IES públicas oferecem ensino de melhor qualidade e desenvolvem atividades fundamentais à formação de seus estudantes e ao desenvolvimento do país, tais como pesquisa e extensão. A autora assevera que para efetiva democratização do acesso e condições de permanência dos alunos, a expansão deve ser postulada no 
polo público da educação superior, o que implica na ampliação de recursos públicos para a expansão, interiorização e manutenção da rede.

Ao analisar o cenário do ensino superior brasileiro, Ristoff (2008) corrobora este pensamento e aponta alguns princípios a serem considerados no estabelecimento de políticas de expansão de vagas nas IFES. Destaca a "expansão agressiva das vagas no ensino superior público, com a consequente e gradual desprivatização do sistema como um todo, permitindo a inclusão de maior contingente dos excluídos" e a "manutenção e melhoria dos padrões de qualidade" das IFES, com a "ampliação significativa do financiamento público". O teórico acrescenta que democratizar significa criar oportunidades para que os milhares de jovens de classe baixa, pobres, filhos da classe trabalhadora e estudantes das escolas públicas tenham acesso à educação superior. Afirma que "não basta mais expandir o setor privado, pois as vagas continuarão ociosas; e não basta apenas aumentar as vagas no setor público, pois elas apenas facilitarão o acesso e a transferência dos mais abastados". Ainda segundo o autor, a democratização precisa de ações mais radicais para acontecer de fato, ações que afirmem os direitos dos historicamente excluídos, e assegurem o acesso e a permanência a todos os que procuram a educação superior.

Os autores que defendem a expansão de vagas nas instituições privadas apresentam argumentos que giram em torno da maior eficiência dessa esfera de ensino, considerando a utilização dos recursos e o custo-aluno, inferior ao do setor público. Além disso, chamam a atenção para a maior flexibilidade administrativa e financeira da rede privada em relação ao sistema público, e afirmam ser impossível, somente pela via pública, o atendimento à demanda por educação superior, em um país continental como o Brasil (CASTRO, 2003; SAMPAIO, 2003).

Nessa visão, evidencia-se a participação das agências internacionais, a exemplo do Banco Mundial, que no documento "La Ensenanza Superior: Las lecciones derivadas de La experiência”, elaborado em 1994, reforça a ideia da educação como sustentáculo para a competitividade social e econômica do país, e defende que o avanço do setor privado é meio eficaz de resolver os problemas de acesso à educação superior, associando o termo democratização da educação superior à privatização/mercantilização desse nível de ensino.

Essa compreensão da educação superior enquanto serviço tem favorecido a adoção de um modelo mercadológico de educação, fortalecido pelo ProUni e pelo 
FIES, por meio dos quais o Governo Federal, ao mesmo tempo em que defende a inclusão social e a democratização da educação superior, transfere recursos para o setor privado e abstém-se de maiores investimentos nas instituições públicas, privilegiando o empresariado, que enxerga este nível de ensino como um grande nicho de mercado.

A intensa expansão do setor privado vem consolidando um vigoroso processo de privatização da educação superior, não raro, pautado por aspectos que colocam em risco uma educação de qualidade, seja pela adoção de estratégias de redução de custos, a exemplo da contratação de professores pagos por hora, o que retira destes profissionais a possibilidade de produção de pesquisas, seja pelo escasso número de bolsas para cursos tradicionais, como medicina e engenharia, ou ainda pelas poucas condições de permanência oferecidas a estudantes de baixa renda nestes cursos que exigem a compra de livros e materiais acadêmicos.

As cifras desembolsadas pelo Estado para financiamento do ProUni e do FIES alcançam altos valores. Apenas com o benefício da renúnica fiscal de quatro impostos no ano de 2013, as instituições privadas deixaram de pagar aos cofres púlbicos cerca de $\mathrm{R} \$ 750$ milhões. Em 2014, os valores destinados ao Prouni cresceram $166 \%$.

Com relação aos gastos com o FIES, foram repassados pelo Estado às instituições privadas em 2014, 13,4 bilhões de reais (Toledo; Saldaña; Burgarelli, 15 Fev 2015). Segundo a ANDIFES (2015), com R $\$ 1$ bilhão seria possível criar 400 mil novas vagas noturnas em instituições federais de ensino superior.

Já o orçamento destinado à educação superior pública, aumentou apenas $86 \%$, percentual insuficiente para atender a demanda, deixando à margem indivíduos pertencentes às camadas de menor poder aquisitivo. Alterar o desenho educacional superior vigente, onde em termos numéricos, as instituições privadas são dominantes, é tarefa complexa, pois contraria interesses econômicos nacionais e internacionais. A necessária mudança deve ocorrer a partir do investimento maior na esfera pública e controle da rede privada, de forma a garantir a transparência da aplicação dos recursos e a qualidade dos cursos ofertados. 


\section{CAPÍTULO 2}

\section{DIVERSIFICAÇÃO NAS FORMAS DE ACESSO E POLÍTICAS DE PERMANÊNCIA NA UNIVERSIDADE DE BRASÍLIA}

$\mathrm{Na}$ primeira parte deste capítulo serão apresentadas as alterações ocorridas nos processos seletivos para ingresso na Universidade de Brasília, desde a promulgação da Lei de Diretrizes e Bases da Educação - LDB/1996, quando o vestibular deixou de ser instrumento hegemônico de seleção para o acesso à educação superior, possibilitando que o Programa de Avaliação Seriada - PAS, fosse adotado como forma alternativa de ingresso na instituição. A segunda parte será dedicada à apresentação do histórico do Enem, objeto de estudo deste trabalho, e às ações atualmente implementadas pela UnB, com vistas à permanência de seus alunos socioeconomicamente vulneráveis.

\subsection{Diversificação na forma de acesso à Universidade de Brasília}

Os tradicionais exames vestibulares, desde sua criação no início do século $X X$ até a promulgação da LDB, mantiveram-se como forma única de acesso à educação superior brasileira. Tornaram-se alvo de críticas por ocorrerem em momento único, desconsiderando a trajetória acadêmica do indivíduo ao longo da escolarização, por não contribuírem no aperfeiçoamento do desempenho individual do aluno, na melhoria da qualidade do ensino médio, e por não auxiliarem na definição de políticas para a educação básica, reproduzindo nas universidades a estratificação social (SOBRAL e OLIVEIRA, 2006).

Em virtude dessa visão crítica em torno do vestibular, tido como mecanismo de perpetuação de privilégios da elite, o MEC promoveu em Brasília, no ano de 1985, o "Seminário Vestibular Hoje", cujo tema teve continuidade em seminários regionais ocorridos em algumas capitais, a exemplo do "1 Seminário sobre o Vestibular da Universidade de Brasília", onde foram discutidas alternativas de seleção para acesso ao ensino superior.

Não obstante as discussões em torno de mudanças nas formas de acesso à educação superior, somente após onze anos, com o advento da LDB-96, estabeleceu-se o fim da obrigatoriedade do exame como instrumento único de 
seleção aos cursos de graduação. A partir daí, uma nova forma de seleção denominada Vestibular Seriado foi colocada em prática. Consiste na realização de provas em três etapas, no final de cada uma das séries do ensino médio, consecutivamente. O conteúdo de cada etapa corresponde respectivamente, aos conteúdos de cada ano do ensino médio. O desempenho em pontos obtidos em cada prova é acumulado e determina o desempenho final do candidato, compondo a nota sua classificação no curso pretendido, opção que é feita apenas no momento de sua inscrição na terceira etapa.

O primeiro Vestibular Seriado surgiu de forma experimental, por iniciativa da Universidade de Federal de Santa Maria (UFSM), em 1995, por meio do Programa Experimental de Ingresso ao Ensino Superior (Peies). Entretanto, a Universidade de Brasília foi pioneira na discussão e busca de estratégias de superação das deficiências dos exames vestibulares tradicionais. Buscava-se a adoção de um modelo que garantisse igualdade de oportunidades na seleção dos candidatos, Independentemente da renda ou da cor.

Para Morhy (1996), então Presidente da extinta Comissão Permanente de Concurso Vestibular da UnB (COPEVE), a universidade precisava contribuir para a elevação do nível dos candidatos ao ingresso na UnB, e uma das maneiras era interagir com o ensino médio. A proposta do PAS é "buscar uma avaliação de aprendizagem significativa, privilegiando a reflexão sobre a memorização, a qualidade sobre a quantidade de informações" (CESPE/UnB). Em 1986, após consolidação das discussões em torno da proposta, o projeto foi apresentado ao MEC.

A primeira prova do PAS, já sob a égide da LDB, foi realizada por alunos do primeiro ano do ensino médio, no ano de 1996, e o ingresso dos aprovados, no primeiro semestre de 1999. Com a possibilidade legal da utilização de formas alternativas de seleção para acesso, diversas instituições aderiram ao novo modelo, cada uma adotando nomenclatura específica. No ano de 2014, 30 instituições utilizaram este tipo de seleção.

Em estudo sobre o acesso à educação superior pública, Vasconcelos e Lima (2004) identificaram que os principais fatores que dificultam o ingresso de pessoas socioeconomicamente carentes às IFES, estão relacionados aos modelos dos processos seletivos das instituições, caracterizados como predominantemente 
elitistas e limitantes das possibilidades de ingresso para a maioria dos estudantes advindos da escola pública.

Oliveira et al. (2008), ao estudarem a implantação dos vestibulares seriados, reconhecem a importância da diversificação nos modelos de seleção para ingresso às IFES. Entretanto, concluem que, mesmo após a implantação dos Programas Seriados de Avaliação, não houve alteração substancial no panorama de seletividade na educação superior. A pesquisa realizada por estes autores demonstrou que, à época do estudo, a maior parte do corpo discente das universidades públicas constituia-se de indivíduos pertencentes a classes abastadas.

Borges e Carnielli (2005) corroboram este pensamento, concluindo que as Avaliações Seriadas mantêm a estratificação social no acesso aos cursos universitários. Sua pesquisa confirma que nos cursos de maior prestígio social, os alunos ingressantes mediante PAS, em sua maioria, são oriundos de escolas privadas, cursaram ensino médio no turno diurno, possuem computador, frequentaram escolas de línguas e preparatórios para o processo seletivo. Assim, os Programas de Avaliação Seriada seriam uma nova via, quiçá um atalho, para que os candidatos oriundos de estratos socioeconômicos mais elevados ingressem de forma mais rápida na educação superior pública.

Bori e Durham (2000) estudaram os processos seletivos de acesso à educação superior e concluiram que instrumentos de seleção meritocráticos apresentam resultados relacionados à origem socioeconômica dos candidatos, perpetuando a elevada marginalização de indivíduos pertencentes a segmentos mais pobres da população, e contribuindo para que a educação seja o principal correlato da pobreza e da desigualdade social no Brasil A esse respeito, Schwartzman (2006) complementa que para a maioria da população, o ensino médio público é a única oportunidade de preparação para o ingresso na educação superior, e que se isto não ocorrer, cabe questionar os objetivos da formação neste nível de ensino.

A proposta de transformação do Enem em instrumento de seleção, expressa que seu novo formato traria um estreitamento da relação entre o ensino médio e o superior, conclamando as IFES a repensarem os conteúdos exigidos para ingresso neste nível de ensino, de forma que o seu acesso, sobretudo nas instituições 
públicas, se torne um futuro possível para maior número de alunos advindos da escola pública.

\subsection{Histórico do Exame Nacional do Ensino Médio - Enem}

Em diversos países, alunos que pretendem a certificação da sua trajetória acadêmica e/ou ingressar no ensino superior são submetidos a exames. Os primeiros exames foram aplicados no século XIX e seu formato clássico é o Abitur alemão, Bac francês e outros exames semelhantes existentes, sobretudo na Europa, como a Maturità italiano.

Nos Estados Unidos, onde a preocupação com os padrões e a qualidade do ensino médio é mais recente, a partir do século $X X$ foram desenvolvidas novas metodologias de avaliação baseadas em testes padronizados. A iniciativa partiu das universidades privadas, que sentiram a necessidade de um padrão externo de referência para a seleção, que pudesse ser combinado com seus próprios critérios de escolha. Foi criado o College Entrance Examination Board que, a partir de 1926, começou a aplicar uma prova padronizada de múltipla escolha, o Scholastic Aptitude Test (SAT).

Essa prova tem sido adotada pelo College Board desde 1941, e os resultados obtidos, desde então, são considerados como comparáveis através dos anos. Em 1947, foi criado o Educational Testing Service, que administra o SAT, e em 1959, foi criado um teste semelhante, o American College Test, requerido especialmente pelas universidades públicas.

O SAT é um exame que busca avaliar a capacidade dos alunos em seus cursos universitários, e não, necessariamente, se eles aprenderam os conteúdos específicos dos cursos de nível médio. São exames voluntários, mas requeridos pela maioria das instituições de nível superior como parte de seus processos de seleção de alunos. Cerca de dois terços dos estudantes que terminam a escola secundária nos Estados Unidos fazem um teste deste tipo, que são solicitados por cerca de três mil instituições.

Universidades de maior prestígio e reconhecimento exigem escores mais altos no SAT de seus estudantes, e estes resultados são públicos. Escolas secundárias utilizam os resultados médios de seus alunos neste exame, para saber 
se o seu ensino é de alto ou baixo padrão, e os próprios governos podem usar os resultados médios da população, ou de grupos populacionais específicos, para estabelecer políticas de melhoria do desempenho escolar. O SAT não é um programa oficial, não é instituído por lei e não é a única forma de avaliação que permite o ingresso no ensino superior dos EUA, e sua principal importância no cenário educacional reside nos números, já que 175 países aplicaram 1.672.395 testes para seleção de vagas em 6.000 instituições, no ano de 2014 (TRAVITZKI, 2013).

No Brasil, foi na década de 1990 que as avaliações externas, baseadas na aplicação de testes em larga escala para a obtenção de resultados de rendimento escolar dos alunos, com ênfase na eficácia e na eficiência das escolas, tornaram-se o carro-chefe das políticas em educação. Segundo Coelho (2008), tais avaliações foram motivadas pela necessidade de aumentar o controle da educação nacional por parte do governo central, introduzindo uma nova lógica de administrar o sistema público, ocorrência também verificada em diversos países desenvolvidos e em toda a América Latina.

Seguindo a cultura internacional de avaliação educacional, nos moldes do SAT (EUA), foi instituído no Brasil, o Exame Nacional do Ensino Médio - Enem, com o objetivo de avaliar o desempenho dos estudantes ao fim da escolaridade básica e, com isso, auxiliar na elaboração de políticas educacionais. O Exame foi criado pela Portaria n.438, de 28 de maio de 1998 - MEC, ainda no governo FHC, para compor o papel do "estado avaliador", característico daquela década. O termo "estado avaliador" foi cunhado a partir da década de 1980, para se referir às políticas adotadas pelos governos neoliberais que enfatizavam a avaliação, passando a admitir a lógica do mercado, por meio da importação para o domínio público de modelos de gestão privada, com ênfase nos resultados ou produtos dos sistemas educacionais (AFONSO, 2005).

Quando foi concebido, o Enem era facultativo e havia a cobrança de uma taxa de inscrição que desestimulava a sua adesão. Segundo dados do Censo da educação superior (INEP, 2011), na primeira edição, o exame contou com cerca de 115.600 participantes. Era basicamente utilizado como primeira fase do vestibular em algumas instituições, em sua maioria privadas. A partir de 2001, o Governo Federal buscou criar condições para que os estudantes participassem do processo seletivo sem a barreira da condição financeira, por meio da isenção de cobrança da 
taxa de inscrição a todos aqueles que estivessem concluindo o ensino médio em escola pública. $A$ isenção foi estendida aos estudantes com bolsa integral na rede privada ou pessoas que comprovassem situação de vulnerabilidade econômica.

A participação no Enem e a obtenção de pelo menos 450 pontos, são prérequisitos para os candidatos ao ProUni, exceto para os professores do quadro permanente, e em pleno exercício na rede pública de educação básica, que ao concorrerem a bolsas em cursos de licenciatura, curso normal superior ou de pedagogia, não precisam cumprir o critério de renda. Podem candidatar-se às bolsas integrais estudantes com renda familiar, por pessoa, de até um salário mínimo e meio, e às bolsas parciais, os candidatos com renda familiar de até três salários mínimos, per capita. Também é necessário que o candidato tenha cursado o ensino médio completo em escola da rede pública, ou em instituições privadas, na condição de bolsista integral.

Desde 2005, o Enem constitui-se requisito para aqueles que desejam candidatar-se a concessão de bolsas de estudos para ingresso nas instituições de ensino superior privado, por intermédio do Programa Universidade para Todos ProUni, contribuindo com a ampliação do acesso à educação superior.

Mudanças no exame para prover especificamente a ocupação das vagas no ensino superior público passam a ser colocadas em prática em 2009, com a aprovação do documento "Proposta à Associação Nacional dos Dirigentes das Instituições Federais de Ensino Superior", pela Secretaria de Educação Superior SESu/MEC, e a consequente utilização do Enem como mecanismo de seleção para $o$ ingresso nas IFES.

Com a alteração do seu caráter unicamente avaliativo e ampliação dos seus usos, o exame passou gradativamente a ocupar papel central no quadro de políticas públicas de acesso à educação superior. Entre as modificações ocorridas no Enem, destaca-se o aumento significativo no número das questões das provas, que até 2008 era de 63 e a partir de 2009, passaram a constituir-se de 180 questões, elaboradas com base em quatro matrizes, uma para cada área de conhecimento, além da redação. As áreas de conhecimento são: (a) ciências humanas e suas tecnologias, (b) ciências da natureza e suas tecnologias, (c) linguagens, códigos e suas tecnologias, e (d) matemática e suas tecnologias. Outra alteração refere-se à aplicação das provas, que ocorriam em apenas um dia e, após a reformulação do 
exame, passaram a ser realizados em dois dias consecutivos, com duração de 04h30 para o primeiro e 5h30 para o segundo, em função da redação.

Em consonância com sua legislação, o Enem busca aferir as competências e habilidades desenvolvidas pelos estudantes ao fim da escolaridade básica. No caso da redação, as competências avaliadas são:

- Demonstrar domínio da norma padrão da língua escrita;

- Compreender a proposta de redação e aplicar conceitos das várias áreas de conhecimento para desenvolver o tema, dentro dos limites estruturais do texto dissertativo-argumentativo;

- Selecionar, relacionar, organizar e interpretar informações, fatos, opiniões e argumentos em defesa de um ponto de vista;

- Demonstrar conhecimento dos mecanismos linguísticos necessários para a construção da argumentação;

- Elaborar proposta de solução para o problema abordado, respeitando os valores humanos e considerando a diversidade sociocultural.

Adotou-se como referência para elaboração e correção das questões, a Teoria de Resposta ao Item - $\mathrm{TRI}^{5}$, que não contabiliza apenas o total de acertos no teste, mas considera as características das questões e o padrão de respostas dos estudantes para o cálculo das notas. Nesse novo processo, duas pessoas com a mesma quantidade de acertos na prova são avaliadas de forma distinta, pois o resultado depende de quais itens foram respondidos corretamente e quais não foram, o que expressa as habilidades diferentes de cada um dos indivíduos. Além disso, as provas são comparáveis ano a ano. Acerca desse aspecto, o MEC argumenta que a adoção da TRI trouxe um importante ganho, uma vez que a comparação anual dos resultados do exame, permite a elaboração de provas diferentes com o mesmo grau de dificuldade.

\footnotetext{
${ }^{5}$ Os primeiros estudos direcionados à TRI datam da década de 60. A Teoria de Resposta ao Item (TRI) é, conforme Andrade (2000), definida como o conjunto de modelos matemáticos construídos para representar aprobabilidade de um indivíduo dar certa resposta a um item em determinado teste. Para isto, leva em consideração parâmetros do item e a habilidade do respondente. Avaliações baseadas na TRI apresentam forte ganho de qualidade e são um incentivo aos alunos para dedicarem mais esforços à multidisciplinaridadedos conhecimentos do que somente à memorização conteúdos.
} 
Em sua nova concepção, o Enem passou a ser utilizado como forma de seleção unificada nos processos seletivos das universidades públicas federais, que passaram a ter autonomia para optar entre quatro possibilidades de uso do exame:

a) como fase única, com o sistema de seleção unificada, informatizado e online;

b) como primeira fase do processo seletivo;

c) combinado com o vestibular da instituição e

d) como fase única para as vagas remanescentes do vestibular.

O Enem constitui-se hoje numa avaliação sistêmica, ao subsidiar a formulação de diversas políticas públicas para a educação. É critério para certificação do ensino médio para aqueles indivíduos que não o fizeram na idade certa. O participante do Enem interessado em obter tal certificação deverá possuir 18 (dezoito) anos completos, até a data de realização do exame. É preciso alcançar 450 pontos em cada uma das áreas de conhecimento das provas e nota acima de 500 pontos na redação. Segundo dados do Inep (2016), na edição 2015, cerca de $11 \%$ dos inscritos com esta finalidade obtiveram êxito e concluíram o ensino médio. $O$ participante do Enem que não obtiver em alguma área do conhecimento, a pontuação mínima para a certificação, pode inscrever-se no próximo ano e necessitará atingir nota mínima apenas na(s) área(s) pendente(s), desde que apresente à Unidade Certificadora a Declaração de Eliminação dos demais componentes curriculares.

Ressalte-se que esta prerrogativa de certificação, com foco na população jovem e adulta que se encontra fora das instituições escolares, por motivos históricos de exclusão econômico-social, tem como efeito colateral a utilização indevida por estudantes regulares do ensino médio, que buscam antecipação de conclusão do ensino médio, com vistas ao ingresso prematuro na educação superior, o que consiste em uma burla ao objetivo principal da ação. Segundo (SANTOS, 2013), esse ato denuncia a lógica meritocrática que, ainda, impera no acesso à educação superior, deixando a impressão de que a posse do certificado destina-se basicamente à formalidade da condição obrigatória para continuidade de estudos e consequente acesso ao mercado de trabalho. 
O Estado buscou com esta ação elevar o número de concluintes do ensino médio e proporcionar maiores possibilidades de acesso à educação superior, ação que é extensiva às pessoas privadas de liberdade. Para atender este público, o MEC firmou convênio com o Ministério da Justiça e em data posterior ao Enem tradicional aplica, nas próprias Unidades Prisionais ou Sócioeducativas, o Enem para Pessoas Privadas de Liberdade - o Enem-PPL, para as quais a retomada dos estudos representa uma porta aberta à ressocialização, possibilidade de colocação futura no mercado de trabalho e elevação da autoestima e restauração da credibilidade perante a sociedade na qual estão inseridas.

Outro uso do Enem direcionado às pessoas privadas de liberdade refere-se à Recomendação n. 44, publicada em 26 de novembro de 2013, pelo Conselho Nacional de Justiça - CNJ. Dispõe sobre atividades educacionais complementares para fins de remissão de pena. $O$ documento orienta os Tribunais que, aos detentos que obtenham certificação do ensino médio via Enem, seja concedida uma quantidade de horas a serem remidas (correspondente à parte da carga horária esperada para o nível médio). Embora o percentual de beneficiados por esta Recomendação não apresente impactos numéricos de participação, e a iniciativa do CNJ não tenha ainda sido regulamentada, é revestida de profunda relevância social, pois se caracteriza como uma forma de ressocialização dos indivíduos privados de liberdade.

Outro importante uso do Enem refere-se ao acesso ao financiamento do ensino superior, por meio do FIES, criado em 1999 na gestão FHC, e ampliado em 2010, quando a concessão do financiamento passou a ter como requisito a participação no exame. O Programa é sucessor do Crédito Educativo, criado em 1976 pelo regime militar. Financia a graduação na educação superior de estudantes matriculados em instituições não gratuitas que tenham tido avaliação positiva do MEC.

Como parte integrante das políticas de expansão da educação superior, foi criado o SiSU, que utiliza as notas do Enem para a ocupação das vagas disponibilizadas por instituições públicas. A adesão à esta plataforma está diretamente relacionada ao Enem, tendo em vista a Portaria Normativa no 21 de 2012, que dispõe: 


\begin{abstract}
Art. $2^{\circ}$ - O Sisu é o sistema por meio do qual são selecionados estudantes a vagas em cursos de graduação disponibilizadas pelas instituições públicas e gratuitas de ensino superior que dele participarem. $\S 1^{\circ}$ - O processo de seleção dos estudantes para as vagas disponibilizadas por meio do Sisu é autônomo em relação àqueles realizados no âmbito das instituições de ensino superior, e será efetuado exclusivamente com base nos resultados obtidos pelos estudantes no Exame Nacional do Ensino Médio - Enem
\end{abstract}

As inscrições são gratuitas e acontecem no primeiro e no segundo semestres de cada ano. Para se candidatar nacionalmente às vagas disponibilizadas pelas instituições de ensino superior, é necessário ter participado do Enem no ano anterior e ter obtido nota maior do que zero na redação (SiSU, 2014). O candidato pode pleitear, por ordem de preferência, até duas opções entre as vagas ofertadas pelas instituições participantes, e também, se for o caso, concorrer às vagas reservadas para cotistas, de acordo com a Lei no 12.711/2012, de 29 de agosto de 2012 (Lei de Cotas) ou ainda às vagas destinadas às políticas afirmativas das instituições. Ao final da etapa de inscrição, são selecionados automaticamente os candidatos com melhor classificação em cada curso, de acordo com as notas obtidas no Enem e eventuais ponderações (pesos atribuídos às notas ou bônus).

Durante o período de inscrições no SiSU, é permitido aos candidatos alterarem, de acordo com a necessidade e conveniência, as duas opções de curso, aumentando assim as chances de serem selecionados. No semestre 2014/1 foram realizadas duas chamadas pelo SiSU e as vagas remanescentes foram ocupadas pela Lista de Espera. A partir do SiSU 2015, houve alteração no edital e é realizada apenas uma chamada, sendo permitido que o participante do Enem, não selecionado pelo Sistema, manifeste em prazo especificado no cronograma, seu interesse em participar da Lista de Espera. Dentro da nova sistemática de chamadas, as IFES publicam edital específico para ocupação das vagas remanenescentes.

Os números demonstram que, ao longo dos anos, a plataforma SiSU vem crescendo em importância e solidificando-se pari passu com o Enem, no cenário das políticas públicas de acesso a educação superior. Observando o Gráfico 2.1, verifica-se substancial evolução no número de instituições aderentes ao SiSU, desde sua criação até o primeiro semestre de 2016. 
Gráfico 2.1 - Demonstrativo do número de instituições participantes do SiSU ( 2010 a 2016).

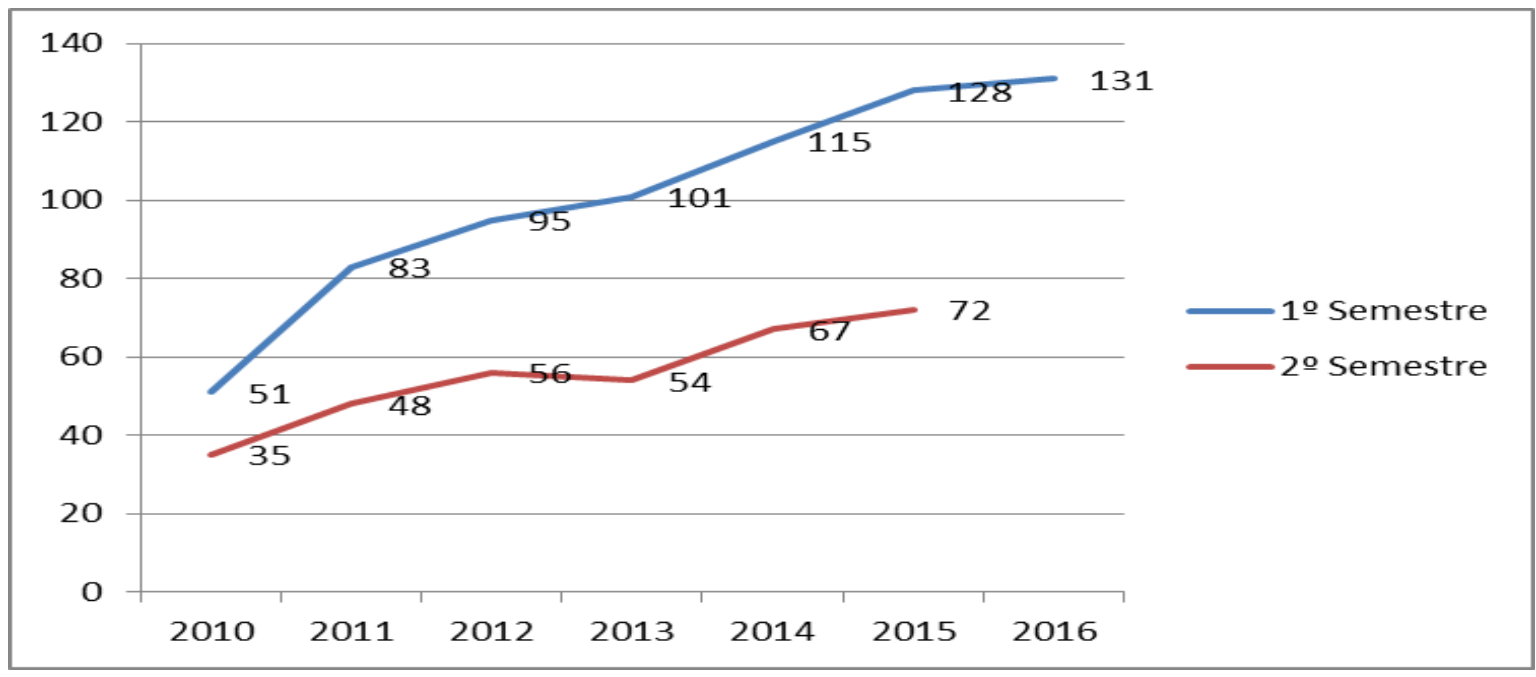

Fonte: MEC/SESu (2016)

Em 2010, no primeiro processo seletivo para ingresso às Instituições Federais de Ensino Superior realizado após criação do Sistema, participaram 51 instituições. $\mathrm{Na}$ seleção para provimento das vagas do primeiro semestre de 2016, contou-se com a adesão de 131 instituições, registrando-se um crescimento de aproximadamente 151\%, com relação à primeira edição do Sistema. Consequentemente, o número de vagas também teve crescimento substancial neste período, conforme demonstra o Gráfico 2.2:

Gráfico 2.2 - Crescimento do número de vagas ofertadas pelas Instituições de Ensino superior, por meio do SiSU (2010 a 2016).

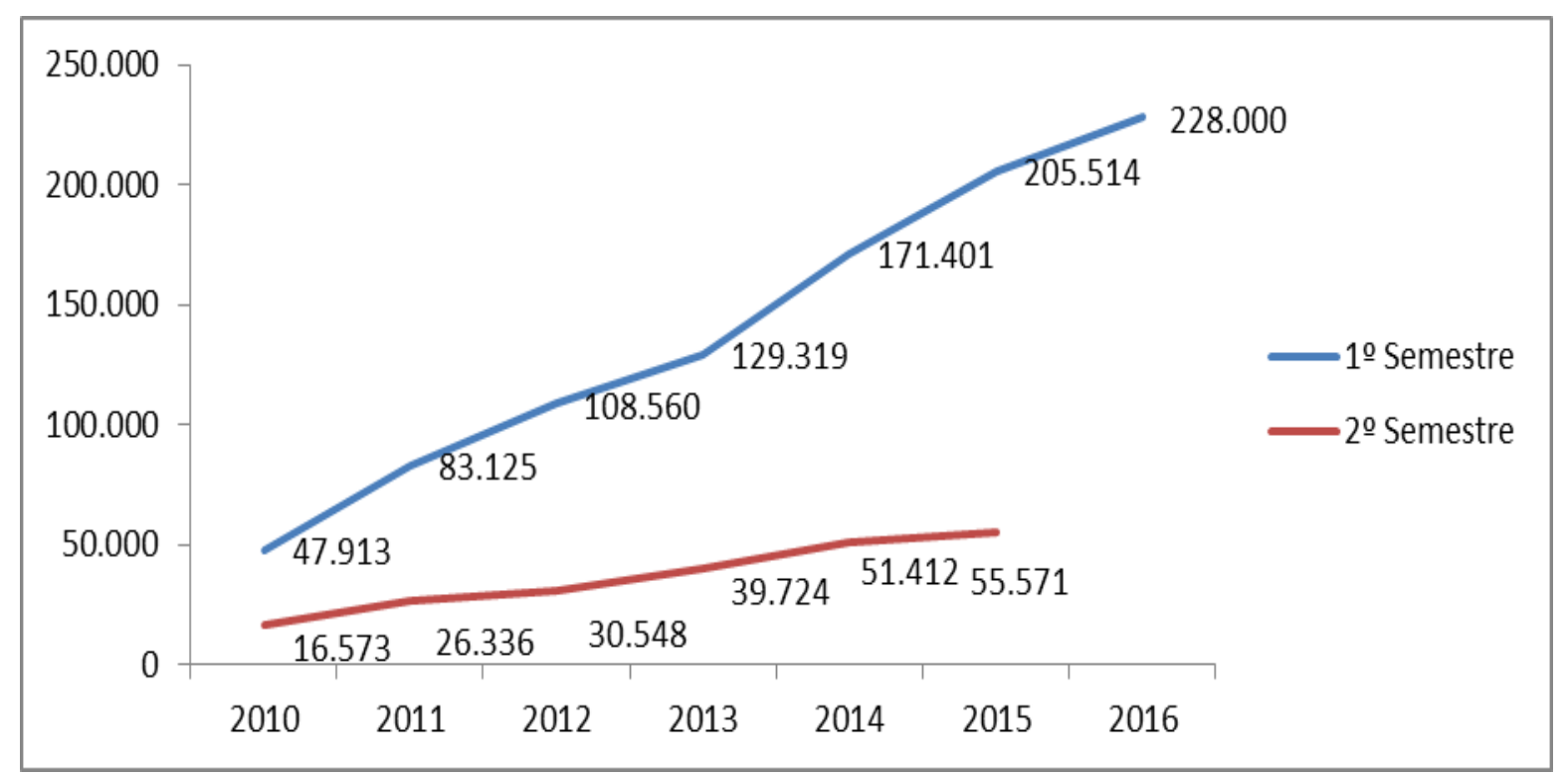

Fonte: MEC/SESu (2016). 
Comparando-se o número de vagas ofertadas em 2010 com aquelas oferecidas para o primeiro semestre de 2016, verifica-se na série histórica apresentada, crescimento de aproximadamente $386 \%$, alcançando o quantitativo de 228 mil vagas distribuídas entre as instituições aderentes ao Sistema. Diferente do número de instituições participantes do Sistema e de vagas ofertadas, o quantitativo de candidatos inscritos no ano 2016, foi menor que o ano anterior, conforme apresenta o Gráfico 2.3:

Gráfico 2.3 - Demonstrativo da evolução do número de inscritos no SiSU (2010 a 2016).

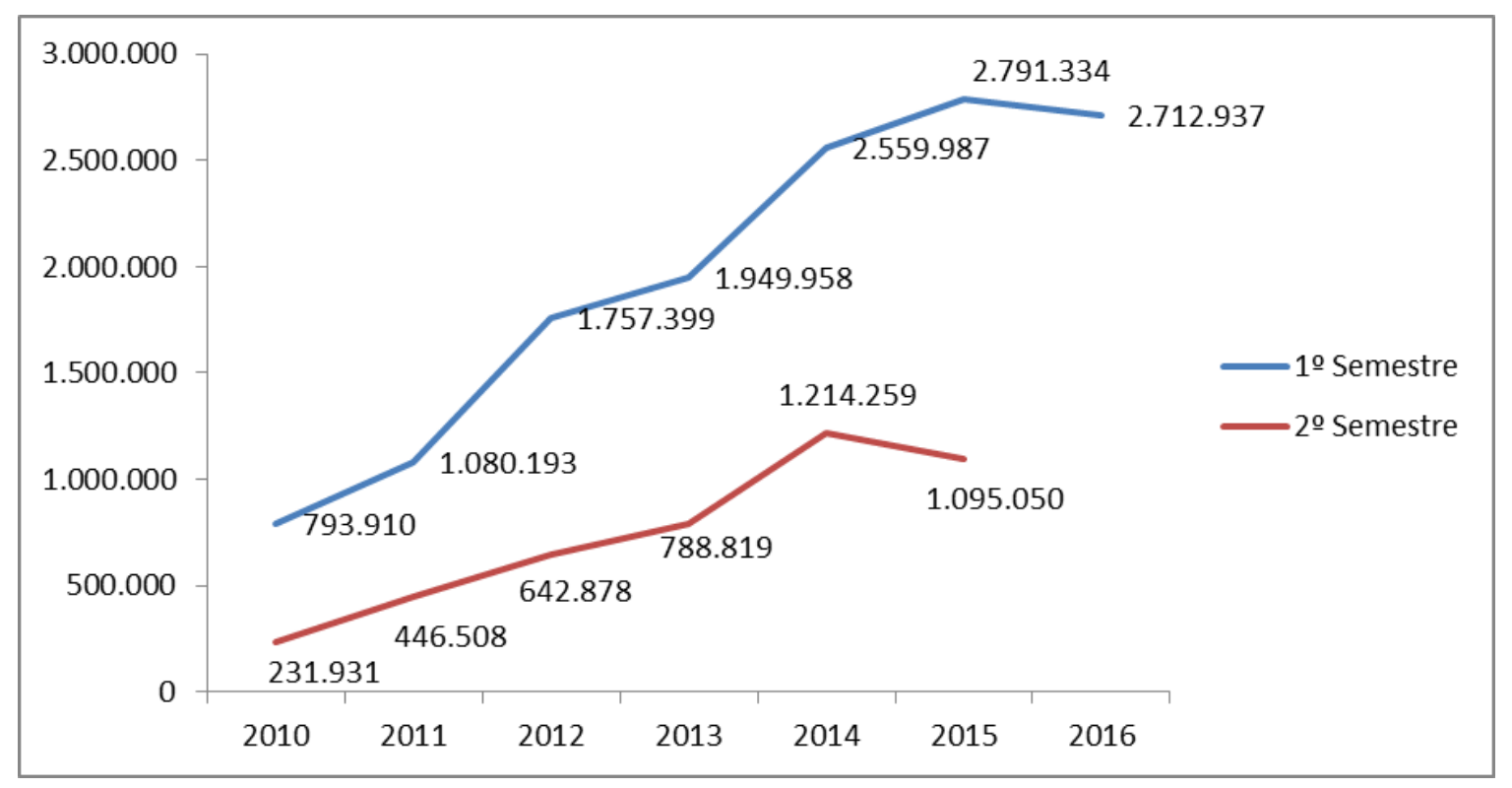

Fonte: MEC/SESu (2016).

Desde a criação do SiSU até o ano de 2015, o número de inscritos no Sistema apresentou significativa evolução. Em 2016, observa-se decréscimo de $2,8 \%$ em relação ao ano anterior, o que pode diretamente ser relacionado à redução do número de inscritos no Enem, uma vez que a plataforma foi criada para atender aos inscritos no Exame.

Mesmo com este decréscimo, os números relativos a instituições aderentes, vagas e quantitativo de inscritos no SiSU, indicam a consolidação desse recurso eletrônico, enquanto plataforma gerenciadora das vagas disponibilizadas pelas Instituições Públicas de Ensino Superior, bem como do Enem, enquanto processo seletivo. 
O Gráfico 2.4 apresenta a evolução quantitativa de inscritos no Exame, desde sua criação:

Gráfico 2.4 - Número de inscritos no Enem (1998 a 2015)

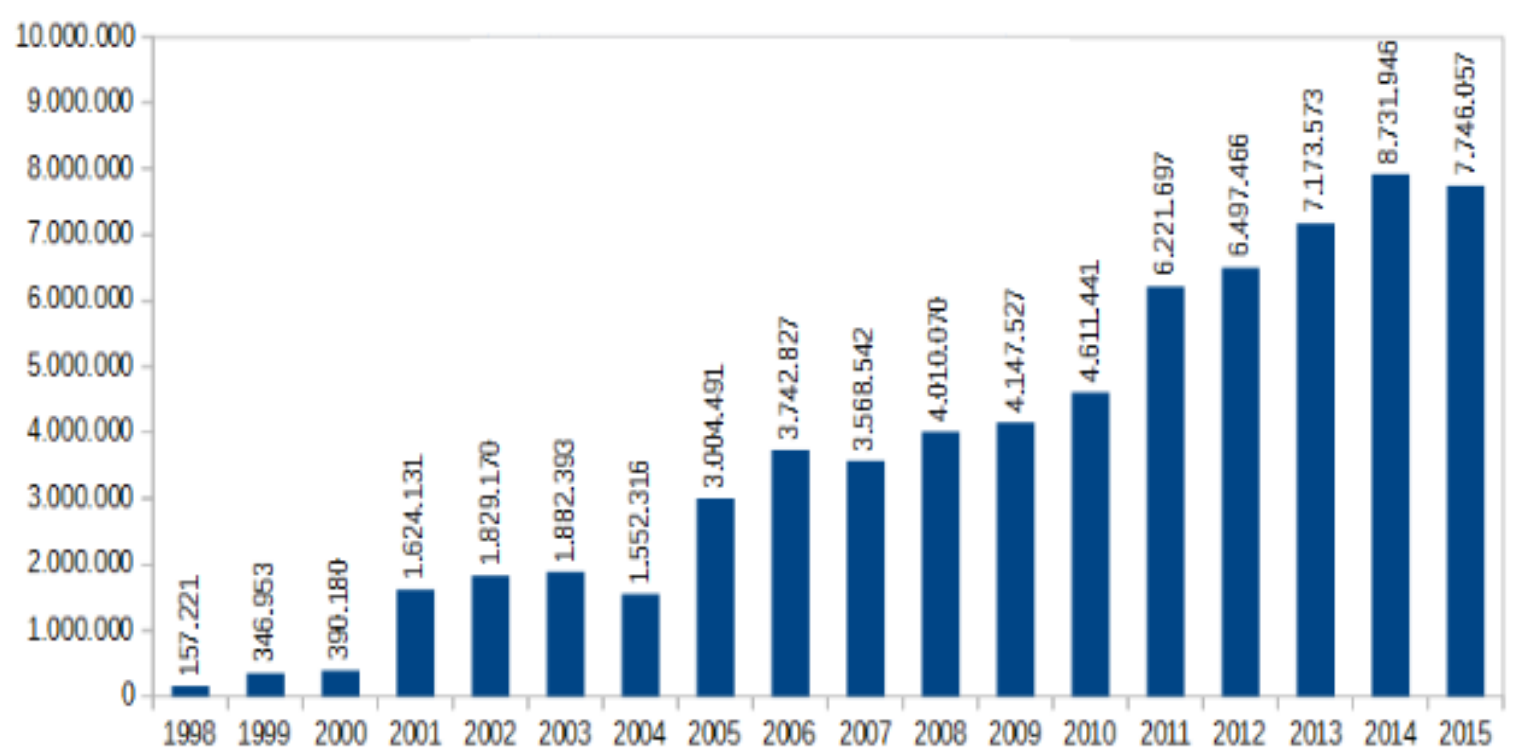

Fonte: Inep/MEC (2016).

Por meio da série histórica, observa-se descréscimo do número de inscritos nos anos de 2004, 2007 e 2015, quando ocorreu redução de 17,5\% em 2004 em relação a 2003, 4,2\% no ano de 2007 em relação a 2006, e 11,2\% em 2015 em relação à edição de 2014.

Em entrevista concedida no ano de 2008, o então ministro da educação, Sr. Fernando Haddad, justifica que a redução de inscritos no ano de 2004 deveu-se ao fato da Universidade Federal do Ceará (UFC) não adotar, naquele ano, o Enem, em seu processo de seleção, o que contribuiu para queda de 90 mil no número de inscrições naquele Estado. Quanto à redução dos números em 2007, a justificativa foi de que, pela primeira vez, os estudantes foram responsáveis por confirmar a inscrição, seja pelos Correios ou pela internet, procedimento antes realizado pelas escolas. A redução do número de inscritos no ano de 2015 , de $11,2 \%$ em relação a 2014, segundo o INEP, é consequência da diminuição de 5 para 3,7 milhões no número de pessoas que solicitaram isenção de taxa de inscrição, em decorrência das regras atuais, que prevêem que os inscritos que forem beneficiados com isenção e faltarem no dia das provas perderão este direito na edição seguinte. 
Ainda analisando o Gráfico 1.4, nota-se que, entre 2008 e 2014, houve mais de $100 \%$ de aumento de inscrições no Enem, com maior percentual de aumento de 2010 para 2011, período de implantação do SiSU, e de 2013 para 2014, em virtude do lançamento do SiSUTEC e do Programa Ciência sem Fronteiras (CsF), que também utilizam as notas do Enem como critério de seleção.

O SiSUTEC utiliza plataforma semelhante à do SiSu. É gerenciado pela Secretaria de Educação Profissional e Tecnológica (SETEC/MEC). Por seu intermédio, instituições públicas e privadas de ensino superior e de educação profissional e tecnológica oferecem vagas gratuitas em cursos técnicos.

O CsF é uma modalidade de intercâmbio criado pelo MEC, em conjunto com - Ministério da Ciência e Tecnologia (MCT) e com o Conselho Nacional de Desenvolvimento Científico e Tecnológico (CNPq), visando promover a consolidação, expansão e internacionalização da ciência e tecnologia, da inovação e da competitividade brasileira, por meio da concessão de bolsas de intercâmbio para alunos de graduação que atinjam nota superior a 600 pontos nas provas do Enem.

Após três anos de implementação, o Programa é alvo de críticas de especialistas em educação, em razão da falta de indicadores que possibilitem a avaliação criteriosa dos seus impactos e resultados. Outro problema apresentado diz respeito ao fato de que muitos estudantes são selecionados para o Programa sem a necessária proficiência da língua, comprometendo o bom desempenho nas atividades acadêmicas. Em estudo recente sobre o Programa, Borges (2014), afirma que o CsF refletiu os aspectos estruturais de desigualdade econômica, racial e de gênero e referendou a inadequação do ensino de inglês na educação básica no Brasil, frente ao contexto da internacionalização da educação superior. Os problemas acima elencados, associados à crise política e orçamentária pela qual passa o país, levaram o governo a congelar a oferta de bolsas que seriam disponibilizadas para o Programa no ano de 2016. Além disso, a expectativa é que quando forem liberadas novas bolsas, estas sejam direcionadas para alunos da pósgraduação.

Com a diversificação dos usos do Enem, a criação do SiSU, e a vinculação do Enem a este Sistema, o volume de inscritos é expressivo, tendo atingido mais de 7,1 milhões de participantes em 2013, cerca de 8,7 milhões em 2014, e aproximadamente 7,7 milhões em 2015. Constitui-se em uma das maiores avaliações de ensino médio do mundo. Em 2015, foi aplicado em cerca de 1.700 
municípios brasileiros, inclusive naqueles mais distantes e de difícil acesso, nunca alcançados por vestibulares realizados regionalmente.

Nacionalmente, mais de 500 instituições utilizam o como processo seletivo único ou parcial, e as 59 universidades federais do país incluem-se nesse número. $\mathrm{Na}$ UnB, o exame foi utilizado de 2011 a 2013, como forma de acesso para as vagas remanescentes do vestibular e do PAS. Com o objetivo de democratizar o ingresso à instituição e diminuir a quantidade de provas realizadas, o Conselho de Ensino, Pesquisa e Extensão (CEPE/UnB) da Universidade de Brasília passou, a partir do primeiro semestre de 2014 , a destinar $50 \%$ das vagas do primeiro semestre letivo de cada ano para candidatos do Enem. A outra metade é ocupada por alunos selecionados pelo PAS. O tradicional vestibular é atualmente utilizado na UnB apenas para seleção no segundo semestre letivo. Segundo dados da Secretaria de Administração Acadêmica da UnB - SAA/UnB, em 2015, a instituição disponibilizou para o SiSU o quantitativo de 1982 vagas em 88 cursos de graduação.

Para efeito de registro acadêmico do ingresso na UnB mediante Enem, utilizase nomenclatura diferenciada dependendo do período de ingresso. Para os ingressantes mediante chamadas do SiSU, consta nos assentamentos acadêmicos, a forma de ingresso "Enem (SiSU)" e para os que ocupam as vagas remanescentes do SiSU, utiliza-se a nomenclatura "Enem". Para melhor clareza das análises dos dados da presente pesquisa, doravante utilizaremos as respectivas denominações de ingresso.

\subsection{Políticas de permanência na Universidade de Brasília}

Conforme já foi demonstrado no decorrer deste trabalho, com a adoção das políticas implementados nas duas últimas décadas, tanto na esfera privada, a exemplo do FIES e ProUni, quanto na esfera pública, destancando-se o Reuni, Enem (SiSU), e Política de Cotas, dentre outros, observa-se um crescimento no número de ingressantes na educação superior e em consequência, uma alteração no perfil do alunado. Observa-se um público heterogêneo nos aspectos étnico, social e econômico. O Fórum Nacional de Pró-Reitores de Assuntos Comunitários e Estudantis (FONAPRACE), a pedido da ANDIFES, realizou pesquisa do perfil dos alunos da graduação nos anos de 1996/1997, 2003/2004 e em 2010. O último 
Relatório (FONAPRACE ${ }^{6}$, 2011) utilizando a metodologia da Associação Brasileria das Empresas de Pesquisas (ABEP) ${ }^{7}$, verificou que $44 \%$ dos estudantes das instituições públicas, no ano de 2011, pertenciam aos extratos "C, D e E", da população, sendo que $46 \%$ estudaram em escolas públicas de ensino médio. Em 2015, quatro anos após a última pesquisa e com a Lei de Cotas vigente, um novo levantamento de dados sobre os alunos da rede federal foi realizado e encontra-se em fase de consolidação dos dados. A partir do diagnóstico, segundo o Fonaprace, serão formuladas diretrizes e políticas públicas de atendimento aos universitários e de defesa da educação pública, gratuita com qualidade acadêmica e científica.

O Relatório Coleman, resultado de pesquisa encomendada pelo governo norte-americano nos anos 60 , investigou mais de quinhentos mil alunos daquele país, matriculados em escolas primárias e secundárias. Os dados da pesquisa mostraram que, naquela década, o fator socioeconômico determinava fortemente 0 desempenho escolar dos estudante e trouxeram à tona a questão das políticas de permanência (SOARES e SERGEI; SÁTYRO e NATÁLIA, 2008).

Estudos posteriores ao Relatório Coleman sobre permanência nas universidades, a exemplo dos de Zago (2009) e Vargas (2010), revelaram que desde a criação das primeiras universidades públicas no Brasil, ações para atendimento às demandas por assistência estudantil eram praticadas pelas IFES, embora de forma individual e desarticulada. Somente a partir da Constituição de 1988 e da LDB, em 1996, estas ações foram institucionalizadas como política e direito social. Destaca-se que a criação do FONAPRACE em 1987, com apoio da ANDIFES, foi um importante avanço no sentido do fortalecimento das políticas de assistência nas IFES.

Apesar da constituição de 1988 e da LDB considerarem a permanência dos estudantes nas IFES um direito, estas prerrogativas jurídicas não destinavam verbas

\footnotetext{
${ }^{6}$ O Fórum Nacional de Pró-Reitores de Assuntos Comunitários e Estudantis (FONAPRACE) é órgão assessor da Associação Nacional dos Dirigentes das Instituições Federais de Ensino Superior (ANDIFES). Criado em 1987 com a finalidade de promover a integração regional e nacional das Instituições de Ensino Superior (IES) Públicas visando fortalecer as políticas de Assistência ao Estudante.

${ }^{7}$ A classificação da ABEP define a classe econômica brasileira, com a finalidade de segmentar as classes econômicas pelo poder aquisitivo. Para tanto, verifica o quantitativo de itens no domicilio, quais sejam: televisores, automóveis, empregados mensalistas e outros, atribuindo-se pontos por item e quantidade encontrada, além de verificar o grau de instrução do chefe de família com a atribuição de pontos.
} 
específicas para atendimento de ações de permanência. No geral, as próprias IFES implementavam e mantinham suas políticas de permanência com recursos próprios, oriundos das chamadas taxas acadêmicas, recursos esses, geralmente, insuficientes para manutenção da política de permanência (FONAPRACE, 2012). Limitavam-se a programas baseados no tripé alimentação, bolsa trabalho/manutenção e moradia, sem atentar para outras formas de vulnerabilidade social. Raros eram os exemplos de programas que fossem além dessas questões.

A atual heterogeneidade do corpo discente nas instituições federais tornou premente a necessidade de se pensar a questão da assistência estudantil numa dimensão mais abrangente, exigindo mudanças estruturais e alterações no funcionamento cotidiano das instituições, de forma que efetivamente seja garantida a permanência dos alunos oriundos de classes menos favorecidas economicamente, levando-se em consideração, além das necessidades elementares (moradia, alimentação e transporte), questões como acesso à cultura, inclusão digital, apoio pedagógico, saúde física e mental, esporte e lazer, enquanto direitos necessários para que os estudantes possam ter uma formação acadêmica vivenciando o cotidiano da universidade de forma plena.

Nessa perspectiva, em 2008, o Plano Nacional de Assistência Estudantil (PNAES) entrou em vigor, pela Portaria Normativa n. 39, de 12 de dezembro de 2007, do MEC, transformada em 2010, por meio do Decreto n. 7.234/2010, em Programa Nacional de Assistência Estudantil. $O$ instrumento legal simboliza um marco na concepção da permanência de estudantes carentes nas universidades e reafirma como objetivos centrais:

I - Democratizar as condições de permanência dos jovens na educação superior pública federal;

II - Minimizar os efeitos das desigualdades sociais e regionais na permanência conclusão da educação superior;

III - Reduzir as taxas de retenção e evasão; e

IV - Contribuir para a promoção da inclusão social pela educação (BRASIL, 2010).

A transformação do Plano em Programa trouxe uma mudança significativa, uma vez que embora os critérios de seleção dos estudantes sejam mantidos sob responsabilidade das IFES, passou a existir maior detalhamento do perfil dos 
estudantes, que devem ser prioritariamente atendidos, como se observa no Artigo 5은 do Decreto:

\begin{abstract}
"Serão atendidos no âmbito do PNAES prioritariamente estudantes oriundos da rede pública de educação básica ou com renda familiar per capita de até um salário mínimo e meio, sem prejuízo de demais requisitos fixados pelas instituições federais de ensino superior" (BRASIL, 2010).
\end{abstract}

A implantação do PNAES representou a garantia de repasse de recursos da matriz orçamentária do MEC, destinados às IFES, exclusivos à assistência estudantil e a gradativa dotação orçamentária, contribuiu sobremaneira para o fortalecimento das políticas de permanência das IFES. Todavia, a democratização da educação superior, na perspectiva de ações de permanência de grupos minoritários, apresenta uma realidade contraditória, mesmo com o incremento, ano a ano, nos valores destinados para esta política. O montante é insuficiente e a demanda pelos atendimentos é cada vez maior. O Gráfico 2.5 apresenta a evolução do orçamento destinado à assistência estudantil no período 2008- 2014.

Gráfico 2.5 - Evolução do orçamento destinado à Assistência Estudantil no período 2008- 2014 (em milhões).

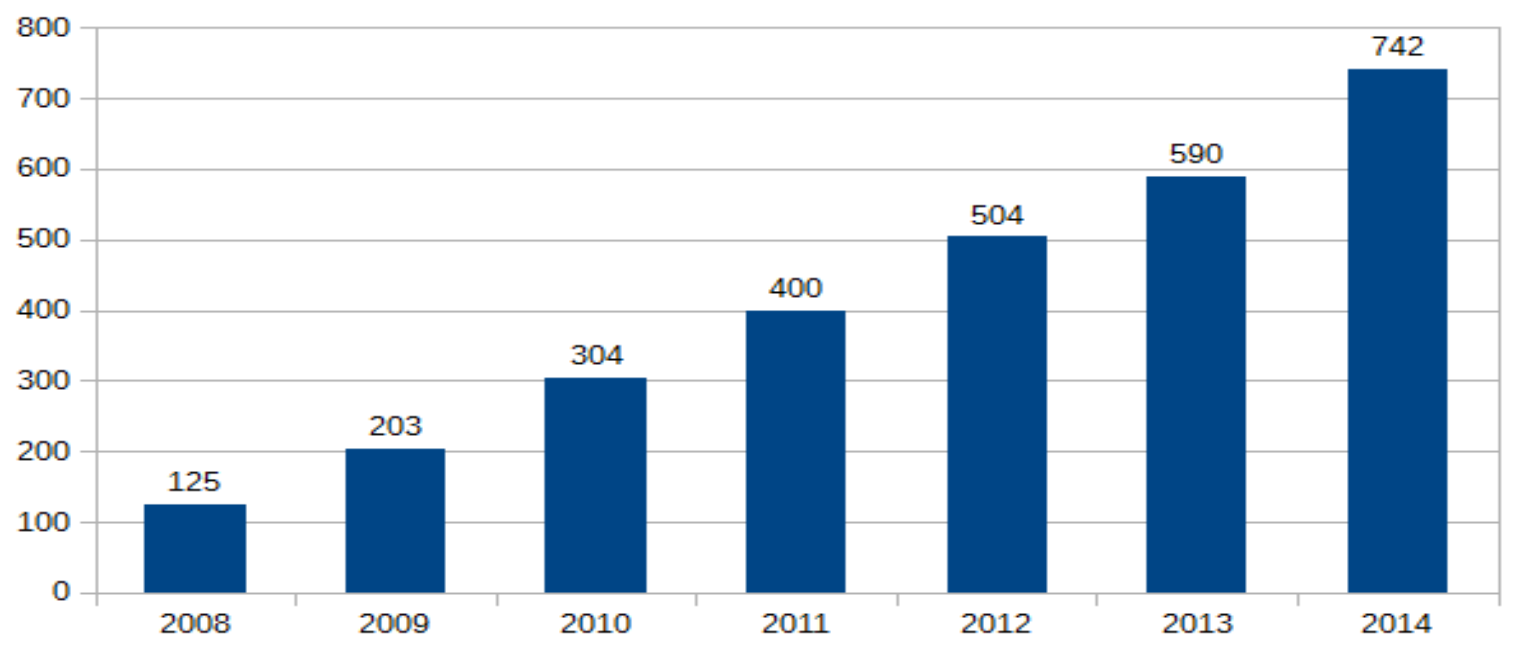

Fonte: FONAPRACE (2015).

Conforme pode-se verificar, o valor disponibilizado pelo governo com vistas ao atendimento da assistência estudantil no ano de 2012 foi de 504 milhões. Entretanto, pesquisas realizadas pelo FONAPRACE, a pedido da ANDIFES, revelaram que naquele ano o valor deveria ter sido de $R \$ 1,5$ bilhão, três vezes mais do que o valor repassado. No ano de 2013, o cenário de insuficiência de recursos para assistência estudantil manteve-se. $O$ montante aplicado totalizou $R \$$ 
590 milhões. Seriam necessários mais que $\mathrm{R} \$ 1,5$ bilhão, para atender as demandas.

Em estudo denominado "As Políticas de Assistência Estudantil: Experiências Comparadas em Universidades Públicas Brasileiras", publicado na Revista GUAL, Assis et al. (2013) propôs descrever e analisar as experiências de onze universidades públicas que possuem ações, projetos e programas nas áreas estratégicas propostas pelo PNAES. A pesquisa apontou que a insuficiência de recursos para o financiamento é um entrave para a execução de uma política eficiente de assistência e retratou os problemas enfrentados e as soluções adotadas pelas instituições pesquisadas, no que se refere à escassez de recursos para as políticas de permanência dos seus alunos.

Entre as situações apresentadas no referido estudo, Assis et al (2013), destaca que no ano de realização da pesquisa, a Universidade Federal de Uberlândia vislumbrava a realização de cortes nos projetos assistenciais, por falta de recursos financeiros. Cita, também, a Universidade Federal de Ouro Preto, que mesmo sendo referência em assistência estudantil, encontrava-se com dificuldades em manter suas ações, utilizando somente os recursos provenientes do PNAES (OLIVEIRA e SARAPU, 2012).

Em meio à exposição das crises enfrentadas por parte das instituições, a referida pesquisa destaca alguns casos de programas de permanência desenvolvidos em universidades, nas quais setores de Assuntos Estudantis atuam em conjunto com Pró- Reitorias ou outros órgãos internos das IFES, formando uma nova estrutura organizacional, que facilita o desenvolvimento de projetos de atendimento às demandas dos alunos. O estabelecimento de parcerias no interior da própria instituição, ou junto a órgãos externos, a exemplo do Ministério da Cultura e do Esporte, é uma orientação do FONAPRACE, no sentido de atenuar as dificuldades vivenciadas pelas IFES.

Exemplo bem sucedido desse tipo de articulação foi a Universidade Federal de Mato Grosso (UFMT), que organizou suas ações de assistência, no interior da Pró-Reitoria de Cultura, Extensão e Vivência (PROCEV), buscando superar os desafios e demandas da instituição. A Universidade Federal do Rio de Janeiro (UFRJ) também desenvolveu parceria similar, a partir da criação da Superintendência de Políticas Estudantis (SuperEst), no ano de 2011, resultado de um processo de articulação entre diversas instâncias da universidade. 
O compartilhamento de ações pode ser eficaz na minimização das dificuldades pelas IFES. Entretanto, a solução dessa questão consiste no aporte de recursos, que possam atender às instituições, na medida das suas necessidades. É importante citar o caso da UFJF, que apresentava, em 2013, quadro amplamente favorável de atendimento às demandas de permanência e que, em 2015, deparouse com a escassez de recursos que faz a administração cogitar a redução do número de bolsas estudantis de 5,5 mil para 4,4 mil, conforme entrevista concedida pelo Reitor Júlio Chebli, a jornal local, em março de 2015.

No âmbito da Universidade de Brasília (UnB), a Diretoria de Desenvolvimento Social - DDS, unidade vinculada ao Decanato de Assuntos Comunitários - DAC, é a responsável pelo planejamento, coordenação, controle e avaliação dos programas e projetos sociais direcionados à comunidade universitária. Seu objetivo é promover a inclusão social dos estudantes em situação de vulnerabilidade econômica, a fim de que estes possam ter a mesma oportunidade de diplomação e rendimento acadêmico que os demais alunos, minimizando a evasão e o trancamento de matrículas. A seleção dos candidados às políticas de permanência ocorre, semestralmente, mediante análise socioeconômica, realizada por profissionais da DDS, e segue o que preceitua o Decreto 7234/2010, em seu artigo 5o, citado anteriormente.

Segundo dados extraídos do Relatório de Gestão da Diretoria de Desenvolvimento Social - DDS (2014), iniciou-se, em 2009, um processo de reestruturação das ações de assistência estudantil em consonância com o PNAES Decreto n. 7.234/2010, com base nos princípios da inclusão social, da igualdade e da equidade. No segundo semestre letivo daquele ano, foram projetados e implementados postos de atendimentos do Serviço de Programas Sociais (SPS) nos três novos Campi - Faculdade UnB Ceilândia (FCE), Faculdade UnB Gama (FGA) e Faculdade UnB Planaltina (FUP). Estes novos postos foram equipados com móveis e computadores, adquiridos com recursos do PNAES, inclusive para uso dos estudantes.

Além da expansão física nos atendimentos, mudanças importantes foram incorporadas no desenvolvimento da Política de Assistência Estudantil da UnB, entre as quais se destacam a ampliação e reestruturação de programas existentes, a maior transparência ao processo de estudo socioeconômico, por meio de editais 
específicos, e o processo de reforma da Casa do Estudante Universitário de graduação.

O ano de 2013 pode ser considerado um período de avanços no que diz respeito às políticas de permanência da instituição, pois houve a retomada da pauta de assistência estudantil na Câmara de Assuntos Comunitários - CAC/UnB, quando foram revistas as resoluções da bolsa permanência e da moradia estudantil de graduação, a aprovação de novas regulamentações, destacando-se as de auxílio emergencial e de alimentação gratuita no Restaurante Universitário para estudantes participantes do Programa bolsa alimentação.

Também, naquele ano, a UnB aderiu ao Programa de Bolsa Permanência PBP/MEC, criado pelo MEC pela Portaria n. 389, de 09 de maio de 2013. O Programa concede auxílio financeiro a estudantes de IES públicas, desde que comprovem vulnerabilidade econômica ou que seja indígena ou quilombola. A DDS incorporou o PBP/MEC entre suas atividades e passou a administrar a inclusão e o acompanhamento de seus estudantes nesse programa.

As ações implementadas em 2013 foram consolidadas em 2014, quando a UnB passou a substituir o vestibular do primeiro semestre pelo SiSU. Nesse ano, foi possível o atendimento de 4.182 alunos nos seguintes programas e ações disponibilizados pela UnB: Programa Bolsa Alimentação, Programa alimentação complementar para estudantes do Programa Moradia, Programa Moradia Estudantil da Graduação, Programa Auxílio Socioeconômico, Bolsa Permanência MEC, Programa Auxílio Emergencial, Programa de Acesso à Língua Estrangeira, Programa vale livro, Serviço de transporte intracampus e intercampus, caracterizados conforme descrito a seguir:

\section{- Programa Bolsa Alimentação}

Todos os estudantes classificados como PPAES têm direito à alimentação gratuita (desjejum, almoço e jantar) nas dependências do Restaurante Universitário (RU), no campus Darcy Ribeiro. Durante o ano de 2014, os campi da Faculdade de Ceilândia - FCE e Faculdade do Gama - FGA foram contemplados com a extensão do RU, beneficiando também os estudantes ali matriculados. Em 2015 foi inaugurado o restaurante universitário do Campus da Faculdade de Planaltina - FUP. - Auxílio alimentação complementar para estudantes do Programa Moradia 
Além dos Programas Bolsa Alimentação e Auxílio Alimentação, a DDS desenvolve ação complementar ao programa bolsa alimentação. Os estudantes PPAES, participantes do Programa Moradia Estudantil da Graduação, recebem um auxílio alimentação complementar de 15,00 (quinze reais por dia) para os dias em que o RU não esteja em funcionamento. Em 2014, o quantitativo de estudantes atendidos por este auxílio complementar foi de 1005 estudantes.

\section{- Programa Moradia Estudantil da Graduação}

O Programa Moradia Estudantil da Graduação - PME-G, caracteriza-se como um dos principais mecanismos para garantir a permanência de estudantes economicamente vulneráveis, que não possuam imóveis no Distrito Federal e cujas famílias residam em outras UFs. Oferece vagas aos estudantes nas modalidades: a) vaga em apartamento na Casa do Estudante Universitário (CEU/UnB); b) Concessão mensal de auxílio financeiro no valor de $R \$ 530,00$ (quinhentos e trinta reais) quando não houver disponibilidade de vagas na CEU/UnB. Aos estudantes PPAES dos Campi FCE, FGA e FUP o benefício da moradia estudantil é disponibilizado, prioritariamente, em forma de pecúnia.

Os prédios que compõem a Casa do Estudante Universitário - CEU, construídos em 1973, foram recentemente reformados, e seu mobiliário foi renovado com recursos financeiros provenientes do PNAES. Hoje, a CEU é composta por dois blocos, localizados no Campus Darcy Ribeiro e oferece 360 vagas divididas em 90 apartamentos do tipo duplex, comportando quatro estudantes em cada unidade.

Segundo dados do Relatório Diretoria de Desenvolvimento Social - DDS/UnB, em 2014, 1.121 estudantes participaram do Programa Moradia Estudantil da Graduação, entre os quais 105 alunos residiram na CEU e 1.016 receberam auxílio moradia em forma de pecúnia. Importante mencionar que a Universidade de Brasília também conta com Programa de Moradia Estudantil para alunos da Pós-Graduação (PME-PG).

- Programa Auxílio Socioeconômico

O Programa Auxílio Socioeconômico da UnB (PASeUnB) consiste na concessão financeira mensal de $R \$ 465,00$ (quatrocentos e sessenta e cinco reais), 
desde que comprovada a situação de vulnerabilidade socioeconômica. O estudante que for beneficiado pode acumular mais de uma bolsa ou auxilio, decorrente de desenvolvimento de atividades de ensino, pesquisa e extensão da UnB ou de programas de assistência estudantil, desde que a soma total dos valores não ultrapasse um salário mínimo e meio. Para acesso ao programa, deverá participar de seleção regida por Edital específico. No ano de 2014, o número de alunos contemplados chegou a 2.436 estudantes.

\section{- Bolsa Permanência MEC}

Em linhas gerais, o Programa Bolsa Permanência - PBP/MEC é um auxílio financeiro que tem por finalidade minimizar as desigualdades sociais e contribuir para a permanência e a diplomação dos estudantes de graduação em situação de vulnerabilidade socioeconômica. O valor estabelecido pelo MEC é equivalente ao praticado na política federal de concessão de bolsas de iniciação científica, atualmente de $R \$ 400,00$ (quatrocentos reais).

Para os estudantes indígenas e quilombolas, é garantido um valor diferenciado, igual a pelo menos o dobro da bolsa paga aos demais estudantes, em razão de suas especificidades com relação à organização social de suas comunidades, condição geográfica, costumes, línguas, crenças e tradições, amparadas pela Constituição Federal. Atualmente o valor é de $R \$ 900,00$ (novecentos reais), sendo o recurso pago diretamente ao estudante por meio de um cartão de benefício.

O PBP/MEC é oferecido para estudantes de etnia indígena ou quilombola nas seguintes condições: ter renda familiar per capita não superior a um salário-mínimo e meio, estar matriculado em cursos de graduação com carga horária média superior ou igual a cinco horas diárias, e não ter ultrapassado dois semestres do tempo regulamentar do curso de graduação em que estiver matriculado. O quantitativo de beneficiados por este Programa, em 2014, foi de 505 alunos.

\section{- Programa Auxílio Emergencial}

Este Programa visa atender as situações inesperadas de estudantes regulamente matriculados em cursos presenciais, desde que estes não estejam inseridos nos demais programas da política de Assistência Estudantil da UnB. O 
estudante poderá receber até o limite de três auxílios no semestre se a situação de vulnerabilidade inesperada persistir. O valor é o mesmo do Auxílio Socioeconômico $(R \$ 465,00)$, e apenas o primeiro auxílio pode ser pago a estudantes que não tenham estudo socioeconômico realizado pela DDS/DAC. Em 2014, foram pagos 384 auxílios emergenciais, com média de 32 benefícios ao mês.

\section{- Programa de Acesso à Língua Estrangeira}

O Programa de Acesso a Língua Estrangeira é uma parceria com a UnB Idiomas, que disponibiliza aos estudantes PPAES isenção da cobrança de matrículas e mensalidades aos estudantes PPAES. As vagas são limitadas a dois alunos por turma.

- Programa vale livro

Em cada semestre é disponibilizado até cinco cupons que permitirão a compras de livros ou material pedagógico da Editora UnB com 50\% de desconto. $\mathrm{O}$ benefício é concedido para estudantes da Assistência Estudantil, matriculados em cursos de graduação ou pós-graduação.

- Serviços de transporte intercampi e intracampus

Com o intuito de promover a integração entre seus Campi, a instituição oferece o serviço de transporte intercampi, gratuito e terceirizado. Para ter acesso, basta que o aluno, professor ou técnico, comprove o vínculo com a UnB. $O$ Transporte intracampus funciona nos mesmos moldes do serviço intercampi, com prioridade para o atendimento de estudantes que participam dos programas da DDS. Este serviço é ofertado somente no campus Darcy Ribeiro, e se propõe a facilitar o acesso aos seus diversos prédios.

As políticas visando à permanência dos estudantes da UnB ganharam maior importância com o incremento de recursos financeiros, que passaram de $R \$ 16,5$ milhões, em 2013, para $R \$ 26,1$ milhões em 2014. A matriz de distribuição dos recursos do PNAES foi concebida da seguinte forma: somente os programas socioeconômicos alimentação, moradia em pecúnia e auxílio emergencial são financiados pelo Programa. 
A universidade que utiliza integralmente o Enem (SiSU) para a seleção dos ingressantes recebe $100 \%$ dos recursos do PNAES, equivalente a $10 \%$ do orçamento anual (excluída a rubrica de pessoal) que a IFES recebe do Tesouro Nacional. Aquelas instituições que utilizam o referido Exame para a seleção de $50 \%$ das vagas recebem $75 \%$ dos recursos, e as que utilizam parcialmente o Exame recebem $50 \%$ do valor. $25 \%$ dos recursos são destinados aos demais casos (CISLAGHI e SILVA, 2011).

Políticas de permanência são peças fundamentais como estratégia de manutenção dos alunos nas IFES. Contudo, o modelo de concepção da matriz de distribuição de recursos do PNAES fere a autonomia das universidades, ao condicionar a distribuição de recursos à adesão ao Enem (SiSU), não deixando alternativa às instituições federais. A própria transformação da portaria de criação do PNAES em decreto, embora apresentada como melhoria no processo de transparência da concessão de bolsas, reduz a autonomia das IFES. A portaria em seu artigo 4ำ previa que os estudantes deveriam ser "prioritariamente selecionados por critérios socioeconômicos", e o decreto aponta que devem ser atendidos "prioritariamente estudantes da rede pública de Educação Básica ou com renda familiar per capita de até um salário mínimo e meio" (art. $5^{\circ}$ ). O Decreto impõe uma politica com horizontes limitados e pautados em ações voltadas para estudantes que se encontrem em determinada condição socioeconômica. Transforma a assistência estudantil em uma ação de combate à pobreza, reduzindo seu caráter de política universal que deveria ser estendida a todos os alunos. Reproduz a lógica de focalização e bolsificação, vigente na assistência social. Não obstante a evolução do orçamento destinado à Assistência Estudantil, demonstrados anteriormente no Gráfico 2.5, por trás desta delimitação do público a ser atendido pela concessão de bolsas, está a insuficiência no aporte de recursos destinados a estas ações e à educação de um modo geral.

A recente aprovação do PNE (2014-2024) determina, na sua vigésima meta, elevar o atual percentual de $5,3 \%$ para $10 \%$ do produto interno bruto (PIB), a porcentagem mínima a ser aplicada na educação pública, nas esferas de governo municipal, estadual e federal. No que tange às oportunidades de acesso na educação superior, há de fato uma expansão de vagas nas IFES, com aumento do acesso de alunos das classes menos favorecidas. No entanto, é necessário ir além 
dos discursos governamentais que colocam a educação como estratégia de desenvolvimento do país, mas que, contraditoriamente, diminuem os recursos imprescindíveis para uma educação democrática. Enquanto a aprovação do PNE acena para maior porcentagem de recursos para a educação, esta área vem sofrendo cortes orçamentários drásticos.

O Plano é constituído de objetivos e metas com quantitativos, prazos e indicação das etapas a serem cumpridas ao longo da sua implementação. As diretrizes do PNE estabelecem que a execução e o "cumprimento de suas metas serão objeto de monitoramento contínuo e de avaliações periódicas" (BRASIL, 2014, Art. 5ㅇ, caput), a serem institucionalmente realizados pelo MEC, pela Comissão de Educação da Câmara dos Deputados e Comissão de Educação, Cultura e Esporte do Senado Federal, pelo CNE e, ainda, pelo Fórum Nacional de Educação (FNE) (BRASIL, 2014, Art. 5o, I a IV). É importante destacar que não há previsão de sanção no caso de descumprimento das metas estabelecidas, o que favorece o negligenciamento no seu cumprimento. Entretanto, a existência de cronograma de etapas e prazos, propicia o acompanhamento e avaliação, pelo poder público e pela sociedade civil, que deve acompanhar e pressionar a execução e o cumprimento integral do Plano. 


\section{CAPÍTULO 3}

\section{METODOLOGIA E RESULTADOS}

O terceiro capítulo traz o percurso metodológico da pesquisa, apresentando os instrumentos e procedimentos de pesquisa utilizados para o alcance dos objetivos propostos neste trabalho, tais como: tipo de abordagem, instrumentos de coleta e de análise dos dados utilizados. Além disso, justifica a escolha dos cursos, sujeitos e semestres analisados. Concluindo o capítulo, são sistematizados, apresentados e discutidos os dados quantitativos provenientes das bases de dados, e os qualitativos, referentes à análise das respostas do questionário aplicado a beneficiários de políticas de permanência da UnB.

\subsection{Abordagem metodológica}

Nas pesquisas nas áreas de ciências sociais e na educação, dois tipos de paradigma disputam lugar: o paradigma quantitativo e 0 qualitativo. Os pesquisadores quantitativistas assumem que existe no mundo uma verdade objetiva que pode ser revelada pelo método científico, cujo enfoque é a dimensão mensurável da realidade. A análise quantitativa, segundo Lima (2003), é uma metodologia que apresenta objetividade, rigor, regras de procedimentos e representatividade estatística. O autor menciona que o seu objeto de estudo são os fenômenos observáveis, passíveis de medição, análise e controle experimental. Em conformidade com essas ideias, Santos Filho (2007) afirma que [...] seu objetivo básico é a predição, a testagem de hipóteses e a generalização. Quando uma pesquisa se vale deste tipo de método, busca analisar a frequência de ocorrência para medir a veracidade ou não daquilo que está sendo investigado.

A abordagem qualitativa permite melhor compreensão do contexto do problema e envolve uma descrição acurada do fenômeno e do cenário social pesquisado, não levando em consideração apenas o ponto de vista das pessoas envolvidas, mas também dos pesquisadores (OLIVEIRA, 1997). Este tipo de abordagem absorve toda a complexidade e particularidade do fenômeno estudado, sem desejar a generalização dos fatos, mas a compreensão e o entendimento das 
suas singularidades. A pesquisa qualitativa se caracteriza por estudar em profundidade uma situação concreta e real, sendo esta abordagem geralmente realizada por meio de questionários.

O questionário, segundo Gil (2007), pode ser definido "como a técnica de investigação composta por um número mais ou menos elevado de questões apresentadas por escrito às pessoas, tendo por objetivo o conhecimento de opiniões, crenças, sentimentos, interesses, expectativas, situações vivenciadas, entre outros fatores". O mesmo autor apresenta as seguintes vantagens do questionário sobre as demais técnicas de coleta de dados: a) possibilita atingir grande número de pessoas, mesmo que estejam dispersas numa área geográfica muito extensa, já que não necessariamente precisa ser aplicado pessoalmente; b) garante o anonimato das respostas; c) permite que as pessoas o respondam no momento que julgar conveniente; e d) não expõe os pesquisadores à influência das opiniões e do aspecto pessoal do entrevistado.

Alguns pesquisadores compreendem que os modelos quantitativo e qualitativo são contraditórios e incompatíveis. Outros defendem que entre os dois instrumentos há uma diversidade complementar e, ainda, há aqueles que conferem a unidade entre os modelos (PIRES, 2008; SANTOS FILHO, 2007). A questão não é escolher o melhor, o superior ou o mais válido, e nem apontar as limitações de cada um, mas utilizar uma abordagem teórico-metodológica que permita atingir resultados que melhor enfatize o fenômeno de estudo.

Corroborando este pensamento, Perrone (1977) afirma que a pergunta fundamental sobre um método não é "se e quanto ele é verdadeiro", mas "se e quanto ele é útil para arar o terreno empírico que temos à frente". O pesquisador, enquanto sujeito ativo do processo de construção do conhecimento pode utilizar e articular os dois modelos, desde que adequados às questões investigativas.

Dessa forma, a escolha metodológica adotada nesta investigação foi a abordagem quantiqualitativa, cujos dados serão apresentados de forma exploratória e descritiva. Exploratória porque, segundo Pinsonneault e Kraemer (1993), torna mais familiar um determinado tópico ou tenta levantar conceitos preliminares sobre o assunto. E de caráter descritivo, tendo em vista o objetivo de descrever o perfil dos ingressantes mediante Vestibular, no semestre 2013/2, ou por SiSU, no semestre 2014/1, nos cursos Direito, Engenharia (Civil, Elétrica, Florestal e Mecânica), História, Matemática, Medicina e Pedagogia, relacionando essas informações com 
as variáveis renda familiar, origem regional e tipo de escola (pública ou privada) cursada no ensino médio, levando-se em consideração, a forma de ingresso dos alunos e o alto ou baixo prestígio social dos cursos.

A opção por pesquisar alunos dos cursos acima elencados, teve por base a associação entre prestígio social dos cursos e nível socioeconômico de seus alunos, temática pesquisada por vários teóricos, os quais afirmam que é comum que cursos de maior valorização social e, potencialmente, de maiores recompensas financeiras, sejam frequentados, em maior parte, por alunos de nível socioeconômico mais elevado. (RIBEIRO e KLEIN, 1982; GOMES 2010), enquanto nos cursos considerados de menor prestígio social, a predominância é de pessoas de origens sociais mais modestas (BORGES e CARNIELLI, 2005; VARGAS, 2009; DINIZPEREIRA, 2011), sugerindo assim, que a seletividade escolar está relacionada à seletividade social.

Pinho (1998) estudou a questão da seletividade social, com o objetivo de verificar as chances de ingresso na Universidade de São Paulo (USP) e dividiu os cursos em dois subgrupos, marcados pela similaridade nas suas características. $O$ subgrupo A, formado pelas carreiras de Medicina, Direito e Engenharia, é caracterizado pela elevada concorrência, consequente menor probabilidade de ingresso e média geral dos cursos maior que a média geral da universidade. $\mathrm{O}$ subgrupo B é constituído pelos cursos da área de humanas, com características opostas às mencionadas no grupo A. O estudo aponta que para os cursos do subgrupo A maior número é de estudantes provenientes de famílias de classe média alta e nos casos do subgrupo $B$, maior heterogeneidade entre os estudantes.

Setton (1999) focou sua pesquisa no prestígio social dos cursos de graduação da USP, atendo-se à área de humanidades. Utilizando os conceitos de capital econômico, social e cultural de Bourdieu, criou três classes de cursos: os seletos, os intermediários e os populares. Sua pesquisa nos remete a refletir sobre o enfoque simplista que se dá à afirmação de que a educação superior é privilégio de uma elite, e nos faz questionar se as universidades estão atentas aos impedimentos de um melhor aproveitamento de seus cursos por estudantes menos favorecidos economicamente.

No âmbito da UnB, Cardoso (2008), em estudo que abordou a Política de Cotas, classificou os cursos em duas categorias: alto e baixo prestígio social, utilizando como critério, a média do argumento final dos aprovados nos cursos. Entre 
os cursos de alto prestígio social, foram incluidos os de Medicina, Direito e Engenharia, cursos historicamente associados ao prestígio e status social, e incluidos em campos de atuação com baixas taxas de desemprego e alta concorrência. Entre os de baixo prestígio foram colocadas as licenciaturas.

A elevada demanda por cursos de alto prestígio na escala social pode ser explicada historicamente. Segundo Azevedo (1996), a escolha das profissões tinha como objetivo elevar o indivíduo a cargos nobres, de preferência com o exercício de atividades intelectuais, de modo a suprir a propriedade da terra e os privilégios de nascimento. As profissões liberais serviam como um elevador social, enquanto as atividades manuais e mecânicas eram reservadas a camadas sociais inferiores da população. A atratividade dessas ocupações explicava-se mais por sua influência social do que pela vocação ou por tendências individuais. Ainda hoje, as profissões de médico, engenheiro e advogado são chamadas "tradicionais" (DINIZ, 2001) ou "imperiais", pelo fato de terem sido constituídas durante o Império, quando a preocupação do país era formar profissionais necessários ao Estado e à elite local (DURHAM, 2005).

Justicando a inclusão de alunos dos cursos de engenharias no grupo estudado, cabe lembrar que com o crescimento nos campos tecnológico nacional e internacional, a demanda do mercado por profissionais nesta área cresceu, surgindo novas vertentes e tornando os cursos atrativos, em razão da diversidade de campo de atuação e da possibilidade de boa remuneração.

Destaca-se que, entre os cursos oferecidos nacionalmente pelo SiSU no segundo semestre de 2015, a maior oferta de vagas ocorreu nos cursos de engenharia, com quantitativo de 30.749 vagas nacionalmente. $\mathrm{Na}$ UnB, são 15 os cursos oferecidos nesta área, sendo dez deles no Campus Darcy Ribeiro (Engenharia Ambiental, Engenharia Civil, Engenharia de Computação, Engenharia de Produção, Engenharia de Redes de Comunicações, Engenharia Elétrica, Engenharia Florestal, Engenharia Mecânica, Engenharia Mecatrônica e Engenharia Química) e cinco ofertados no Campus da cidade do Gama (Engenharia Aeroespacial, Engenharia Automotiva, Engenharia e Eletrônica, Engenharia de Energia e Engenharia de Software), para os quais foram oferecidas no total 205 vagas, com 20 vagas para cada uma das áreas, com exceção do curso de Engenharia de Produção, para a qual foram ofertadas 25 vagas. Considerando as diversas opções nos cursos de Engenharia, restringiu-se a amostra às engenharias 
mais tradicionais: Engenharia Civil, Engenharia Elétrica, Engenharia Florestal e Engenharia Mecânica.

Quanto à inclusão na pesquisa dos alunos dos cursos de História, Matemática e Pedagogia, pode-se valer dos estudos de Gatti e Barreto (2009), que ao investigarem os impasses e desafios da profissão docente, concluíram que, no caso de alunos provenientes de famílias com menores recursos, a opção por cursos de licenciatura, está intimamente ligada ao desejo de melhoria da qualidade de vida, constituindo-se a graduação em maior garantia de empregabilidade, apesar do pouco reconhecimento social e salários menos atrativos. Segundo os autores, o ingresso nestes cursos se dá de forma condicionada e pela concatenação de uma série de variáveis socioeconômicas, entre as quais figuram como mais importantes a questão da renda e da origem escolar.

Bastos (2004) menciona que embora exista preocupação dos alunos de camadas sociais menos favorecidas com relação à escolha de suas profissões, por questões socioeconomicas, abrem mão de pleitear cursos de alto prestígio, os quais Ihes exigiriam maior tempo de preparação e recursos financeiros, optando por carreiras menos disputadas e pouco rentáveis. Similarmente, Vargas (2010), afirma que "ainda existe um grau de seletividade prévia observado pela grande concentração de candidatos de alto poder aquisitivo, em cursos de elevado prestígio social, para os quais são selecionados os que obtêm melhores resultados nas provas.

No presente estudo, no intuito de abarcar maior diversidade possível dos cursos da UnB, incluindo tanto alunos oriundos de classes mais abastadas quanto aqueles menos favorecidos economicamente, valeu-se dos estudos de Cardoso (2008) na abordagem de categorização dos cursos, elegendo-se dentro do universo discente da UnB, alunos matriculados em três cursos considerados de alto prestígio social: Direito, Engenharias (Civil, Elétrica, Florestal e Mecânica), Medicina, e três classificados de baixo prestígio social: História, Matemática e Pedagogia.

\subsection{Amostra e obtenção dos dados}

Elegeu-se como locus desta pesquisa, a Universidade de Brasília (UnB). Conforme dados da Secretaria de Administração Acadêmica-SAA/UnB (2014), a população discente da instituição é atualmente composta de 36.135 alunos 
regulares na graduação, e 8.003 na pós-graduação. A UnB é constituída por 26 institutos e faculdades e 21 centros de pesquisa especializados. Oferece 109 cursos de graduação, sendo 31 noturnos e 10 cursos a distância. Os cursos de graduação estão divididos em quatro campi: Darcy Ribeiro (Plano Piloto), Planaltina, Ceilândia e Gama.

Em razão das atuais políticas públicas educacionais de acesso à educação superior, a exemplo da Política de Cotas e do Enem (SiSU), é perceptível a mudança no perfil do alunado, atualmente caracterizado por maior heterogeneidade étnica, cultural e socioeconômica.

Para a análise quantitativa da pesquisa, foram utilizadas bases de dados secundárias, na forma de microdados, referentes aos ingressantes na UnB, mediante vestibular no semestre 2013/2 (primeira chamada) nos cursos de Direito, Engenharia (Civil, Elétrica, Florestal e Mecanica), História, Medicina e Pedagogia, bem como os microdados referentes aos alunos que ingressaram via SiSU (primeira chamada e segunda chamadas) dos cursos acima mencionados, no semestre 2014/1. Foram consideradas as variáveis origem regional dos estudantes, tipo de escola cursada (pública ou privada) e renda familiar, as quais foram correlacionadas com o prestígio social dos cursos e a forma de ingresso, a fim de traçar o perfil socioeconômico da amostra pesquisada.

Optou-se por desenvolver a pesquisa com alunos ingressantes nos períodos 2013/2 e 2014/1 considerando o fato de que, desde o semestre 2011/1 até 2013/2, o Enem foi utilizado na UnB apenas para ocupação das vagas remanescentes do vestibular e do PAS, e que só a partir do semestre 2014/1, por decisão do CEPE/UnB, a instituição passou a destinar $50 \%$ das vagas do primeiro semestre letivo de cada ano para participantes do Enem (SiSU).

No que se refere aos alunos ingressantes mediante Vestibular, a base de dados secundários, composta de 510 alunos, foi disponibilizada pelo Centro de Seleção e Promoção de Eventos - CESPE/UnB, mediante autorização formal do Decanato de Graduação da UnB - DEG/UnB (ANEXOS 1). No caso dos ingressantes mediante Enem (SiSU) - (185 alunos da primeira e segunda chamadas), os dados foram disponibilizados pelo próprio Decanato de Graduação.

As informações sobre a origem regional dos estudantes, o tipo de escola que cursaram o ensino médio (pública ou privada) e a renda mensal familiar foram obtidas nos Questionários Socioculturais - QSCs respondidos pelos alunos que 
ingressaram mediante vestibular e nos Questionários Socioeconômicos - QSEs respondidos pelos alunos ingressantes por meio do SisU. No ato da inscrição no processo seletivo, os estudantes devem, obrigatoriamente, preencher o instrumento, por meio eletrônico, embora não seja obrigatória a resposta a todas as perguntas que compõem o questionário.

Complementarmente à análise quantitativa, foi realizada pesquisa exploratória por meio de questionário, constituído de 23 questões, sendo 22 do tipo fechada e 01 do tipo aberta, divididas em três blocos (ANEXO 2), visando identificar em que medida as políticas oferecidas pela UnB têm contribuído para a permanência dos alunos participantes da pesquisa. Para tanto, foi solicitado à DDS relação dos alunos beneficiários das referidas políticas de permanência (ANEXO 2), no semestre 2014/1 e matriculados nos cursos pesquisados. De posse dos dados, o instrumento foi encaminhado, por e-mail, para 246 alunos constantes da listagem, independente de terem sido ou não contemplados com as políticas de permanência.

\subsection{Análise dos dados}

Os dados coletados foram tratados quantitativa e qualitativamente, de acordo com a especificidade dos instrumentos e dos objetivos específicos. Para a análise dos dados quantitativos, foi realizada estatística descritiva, com a elaboração de gráficos, tabelas e quadros, para apresentação da frequência e porcentagem das variáveis estudadas. Na estatística inferencial, utilizou-se o pacote estatístico Statistical Analysis 9.1 (SAS,1999), para a realização do Teste de Proporção da análise da variável origem regional. Para essa última análise, apresenta-se alguns conceitos que foram utilizados, conforme Vairinhos (1996):

\section{- Teste de hipótese}

O objetivo de um teste de hipótese é decidir, com base em uma amostra da população, qual de duas hipóteses complementares é verdadeira, ou seja, a ideia central desse procedimento é levantar uma hipótese referente a determinada característica da população, e probabilisticamente verificar se os resultados encontrados condizem com a hipótese levantada. A construção desse teste tem como procedimento estabelecer:

$\mathrm{H}_{0}$ (Hipótese nula): Hipótese que será testada no procedimento probabilístico; 
$\mathrm{H}_{1}$ (Hipótese alternativa): Caso o procedimento probabilístico sugira uma rejeição de $\mathrm{H}_{0}$, é necessário supor uma hipótese alternativa que será aceita.

Em um Teste de Hipótese existem dois tipos de erros: o erro tipo I, rejeitar $\mathrm{H}_{0}$ sendo a mesma verdadeira, e o erro tipo II, não rejeitar $\mathrm{H}_{0}$ quando a mesma é falsa. O procedimento probabilístico se resume em estudar esses dois tipos de erro, mais especificamente o erro tipo I que tem os conceitos:

- Nível de significância $(\propto)$

É a probabilidade de ocorrer o erro tipo I, ou seja, a probabilidade de rejeitar a hipótese nula quando a mesma é verdadeira. Por exemplo, se indicarmos um nível de significância de $5 \%$, teremos uma possibilidade de 5 em 100 de rejeitar a hipótese, sendo essa verdadeira.

- P-valor

O p-valor ou nível descritivo indica a probabilidade de se ter uma observação igual ou mais extrema que a observada na amostra, com a hipótese nula sendo verdadeira. $\mathrm{O} p$-valor resume o teste, se obtivermos um $p$-valor menor que o valor de significância proposto, se rejeita $\mathrm{H}_{0}$. O valor de significância utilizado neste estudo foi de $5 \%$ e os testes realizados no presente trabalho foram de proporção.

\section{- Teste de Proporção}

O teste de Proporção tem como objetivo a comparação de duas proporções. Tem como princípio avaliar a diferença do valor esperado, valores "que a gente esperaria observar" caso a hipótese nula (proporção igual para os dois grupos) fosse verdadeira, com os valores observados. A estatística do teste segue distribuição quiquadrado com 1 grau de liberdade.

Quanto à escolha das variáveis utilizadas neste estudo, valeu-se das teorias de Richardson (2011), segundo o qual, o primeiro procedimento para a realização de um estudo quantitativo é identificar as variáveis específicas para explicar as características do problema. Diante desta orientação optou-se por estabelecer a correlação entre as variáveis, origem regional, renda familiar e tipo de escola cursada no ensino médio (pública ou privada). 
Para a variável que indica a origem regional dos selecionados, estabeleceuse como categorias norteadoras a Unidade da Federação (UF) onde os candidatos residiam no ato da inscrição. Essas informações constam nos questionários respondidos pelos candidatos no ato da inscrição nos processos seletivos.

A variável renda envolveu o rendimento financeiro da família, autodeclarado pelos alunos nos questionários respondidos no momento da inscrição do vestibular ou SiSU. Originalmente, as faixas de categoria de renda familiar dos alunos não são apresentadas de forma similar, nas bases de dados do vestibular e Enem (SiSU). A base de dados dos alunos que ingressaram mediante vestibular possui oito categorias de faixa de renda, em número de salários mínimos: Até 1 salário mínimo; De 1 até 2 salários mínimos; De 2 até 3 salários mínimos; De 3 até 6 salários mínimos; De 6 até 10 salários mínimos; De 10 até 14 salários mínimos; De 14 até 20 salários mínimos; Mais de 20 salários mínimos; Não sei.

A base de dados do Enem (SiSU) constitui-se de quatro faixas de renda, apresentadas em valores que correspondem a salários mínimos: Até 3 (até $R \$$ 1.866,00; De 3 até $10(R \$ 1.867,00$ até $R \$ 6.220,00)$; Mais de 10 até 20 ( $R \$$ $6.221,00$ até $R \$ 12.440,00)$; Mais de 20 até $30(R \$ 12.441,00$ até $R \$ 18.660,00)$. No intuito de possibilitar melhor comparação entre as rendas dos alunos ingressantes pelo vestibular e Enem (SiSU), optou-se por adaptar a categoria de faixa do vestibular à faixa de renda apresentada no questionário do Enem (SiSU), conforme apresentado no Quadro 3.1. Ao fazer a escolha por tal adaptação, foi observado que a segunda faixa de renda, no caso do Enem (SiSU) - (3 a 10 salários) - 1.867,00 até $R \$ 6.220,00$, compõe-se de intervalo extenso, que pode abarcar indivíduos de diferentes classes econômicas. Ainda assim, optou-se por manter o intervalo, a fim de preservar fidedignidade com as faixas de renda do instrumento preenchido pelos alunos ingressantes pelo Enem.

Quadro 3.1 - Categorias de renda familiar utilizada para avaliar o perfil socioeconômico dos alunos da amostra.

\begin{tabular}{|l|l|}
\hline Salários mínimos & Valor em Reais $(\mathbf{R} \$)^{*}$ \\
\hline menor que $\mathbf{3}$ & até $1.866,00$ \\
\hline $\mathbf{3}$ a $\mathbf{1 0}$ & $1.867,00$ até $\mathrm{R} \$ 6.220,00$ \\
\hline $\mathbf{1 1}$ a $\mathbf{2 0}$ & $6.221,00$ até $\mathrm{R} \$ 12.440,00$ \\
\hline $\begin{array}{l}\text { maior que } \mathbf{2 0} \\
\text { Não sei }\end{array}$ & superior a $12.441,00$ \\
\hline
\end{tabular}

* Valores referentes ao ano de 2014, quando o salário mínimo era $\mathrm{R} \$ 622,00$ 
Quanto à variável tipo de escola cursada no ensino médio (se pública ou particular) foi considerada um dado importante na análise do perfil socioeconômico, tendo em vista a forte relação, no nosso país, entre a qualidade da educação básica e o acesso à educação superior. Para análise desta categoria, foram considerados estudantes originados de escola pública, apenas os alunos que cursaram integralmente o ensino médio nessa esfera.

Os resultados das análises quantitativas foram dispostos de forma que se conseguisse, em um primeiro momento, um panorama geral dos objetos do estudo, por meio de análises descritivas, e em uma segunda etapa, no caso da variável origem regional, identificar a disparidade entre os grupos estudados, por meio da utilização de testes com significância estatística.

Com a análise do questionário aplicado aos alunos solicitantes das politicas de permanência, segunda parte da pesquisa, objetivou-se articular a discussão das respostas obtidas com os resultados quantitativos. Para tanto, os dados qualitativos foram sistematizados em gráficos, quadros ou tabelas, e para o detalhamento das respostas à pergunta aberta, optou-se pela análise de conteúdo, que segundo Bardin (1977), é "um conjunto de técnicas visando obter, por procedimentos sistemáticos e objetivos de descrição do conteúdo das mensagens, indicadores, que permitam a inferência de conhecimentos relativos às condições de produção/recepção destas mensagens". Seguindo a metodologia de análise de conteúdo deste autor, realizouse a categorização das respostas, alocando-as em temas emergentes, referentes às possíveis melhorias nas políticas de assistência estudantil implementadas pela UnB.

\subsubsection{Análise Quantitativa}

Para a análise quantitativa considerou-se a origem regional dos alunos, (se residiam ou não no Distrito Federal, antes do seu ingresso na UnB), tipo de escola cursada no ensino médio (pública ou privada), e a renda familiar dos respondentes de cada uma das questões do questionário aplicado.

\subsubsection{Quantitativo de alunos ingressantes}

Iniciou-se o delineamento do perfil dos alunos pesquisados, por meio da elaboração da Tabela 3.1, que apresenta o número de vagas ofertadas e vagas 
preenchidas na UnB, na primeira chamada do Vestibular, semestre 2013/2 e primeira e segunda chamadas do SiSU ${ }^{8}$ - primeiro semestre de 2014.

Tabela 3.1 - Vagas ofertadas e vagas ocupadas na UnB, por meio do Vestibular - semestre 2013/2 (primeira chamada), e Enem-SiSU (primeira e segunda chamadas) - semestre de 2014/1, nos cursos de Direito, Engenharia (Civil, Elétrica, Florestal e Mecânica), História, Matemática, Medicina e Pedagogia.

\section{Vestibular}

\section{Enem (SiSU)}

\begin{tabular}{lcccccc}
\hline & $\begin{array}{c}\text { Ofertadas } \\
\text { Frequência }\end{array}$ & \multicolumn{2}{c}{ Ocupadas } & \multicolumn{2}{c}{ Ofertadas } & \multicolumn{2}{c}{ Ocupadas } \\
Freq & $\%$ & Frequência & Freq. & $\%$ \\
\hline Direito & 120 & 104 & 84,6 & 60 & 39 & 65,0 \\
Engenharia Civil & 40 & 35 & 87,5 & 20 & 16 & 80,0 \\
\hline Engenharia Elétrica & 40 & 35 & 87,5 & 20 & 10 & 50,0 \\
Engenharia Mecânica & 40 & 35 & 87,5 & 20 & 10 & 50,0 \\
\hline Engenharia Florestal & 50 & 35 & 70,0 & 25 & 15 & 60,0 \\
História (Bacharelado) & 40 & 35 & 87,5 & 20 & 11 & 55,0 \\
\hline História (Licenciatura) & 40 & 35 & 87,5 & 20 & 11 & 55,0 \\
\hline Matemática(Bacharelado) & 36 & 32 & 88,8 & 18 & 10 & 55,5 \\
\hline Matemática (Licenciatura) & 32 & 31 & 96,8 & 16 & 10 & 62,5 \\
Medicina & 36 & 31 & 86,0 & 18 & 12 & 66,6 \\
\hline Pedagogia & 118 & 102 & 86,4 & 59 & 41 & 69,5 \\
\hline Total & 592 & 510 & 86,1 & 296 & 185 & 62,5 \\
\hline
\end{tabular}

Nota: Embora seja 41 o número de ocupantes das vagas mediante Enem (SiSU) nocurso de Pedagogia - semestre 2014/1, as análises levarão em conta apenas 21 alunos, aos quais tivemos acesso aos Questionarios Socioeconômicos.

Conforme a Tabela 3.1 , dos seis cursos analisados na pesquisa, foi observado no total de vagas ocupadas nas primeiras chamadas do vestibular e SiSU, maior percentual de estudantes mediante Vestibular, para o curso de Matemática (Licenciatura) e Matemática (Bacharelado) com 96,8\% e 88,8\%, respectivamente, seguido dos cursos de Engenharia Civil, Engenharia Elétrica, Engenharia Mecânica, História Licenciatura e História Bacharelado, todos com $87,5 \%$. Nesta forma de acesso, o curso com menor percentual de ingressantes foi Engenharia Florestal, com $70 \%$ de ingressantes. No total, o Vestibular selecionou para os cursos da amostra, no semestre 2013/2, 510 estudantes.

\footnotetext{
8 Utiliza-se na UnB, nomenclaturas diferenciadas para designar a forma de ingresso dos alunos ingressantes mediante Enem, dependendo do período de ingresso. Para ingressantes mediante as notas do Enem, a partir do semestre 2014/1, quando o exame passou a dividir as vagas do primeiro semestre de cada ano com o PAS, adota-se a forma de ingresso "SiSU" e para os que ocuparam as vagas remanescentes, utiliza-se a nomenclatura "Enem". Para melhor entendimento das análises, doravante utilizaremos as respectivas denominações de ingresso.
} 
Para o ingresso mediante Enem (SiSU), no ano de 2014, o número de vagas ocupadas nas duas chamadas nos cursos pesquisados foi de 185. O maior percentual de alunos ocorreu no curso de Engenharia Civil, com $80 \%$ de ingressantes, seguido de Pedagogia com 69,5\% e Medicina com 66,6\%. A menor frequência foi observada nos cursos Engenharia Elétrica, Engenharia Mecânica com $50 \%$ de ingressantes.

Conforme é sabido, nos processos seletivos do primeiro semestre de cada ano, a Universidade de Brasília divide o número de vagas entre o PAS e o Enem (SiSU). Mesmo considerando este aspecto, observa-se na Tabela 3.1, proporcionalmente percentual maior de ocupação de vagas pelo ingresso mediante vestibular, com 86,1 em relação a 62,5 pelo Enem (SiSU). Este fato pode ser atribuído, em parte, à possibilidade propiciada pelo SiSU, de o aluno poder escolher, por ordem de preferência, até duas opções entre as vagas ofertadas por instituições participantes do Sistema. É possível que alguns participantes tenham optado pela segunda opção de curso, por ser mais próxima de seus domicílios, ou ainda, que tenham ocupado vaga no curso de sua preferência em instituição privada, utilizando-se do Prouni ou FIES.

Outra hipótese relacionada ao não preenchimento de todas as vagas disponilibizadas pelo SiSU, refere-se às politicas de permanência. Ao serem selecionados pelo SiSU, parte dos alunos oriundos de outras Unidades da Federação, e que necessitam das políticas de permanência, não tem conhecimento de que as Instituições Federais as disponibilizam ou não se sentem seguros quanto à garantia de que serão beneficiados por tais ações, o que pode levá-los à desistência da vaga conquistada.

Até 2014, as chamadas para ocupação das vagas remanescentes do Enem (SiSU) eram efetuadas pelo SiSU. A partir de 2015 este sistema realiza apenas uma chamada dos selecionados e a Lista de Espera, que é encaminhada às IFES, que realizam as chamadas para ocupação das vagas remanescentes. A alteração foi uma solicitação dos Pró-Reitores de Graduação das Universidades Federais, com a justificativa que esta inovação traria celeridade ao processo de seleção, uma vez que com o modelo adotado até 2014, não havia preenchimento total de vagas em nas chamadas do Enem (SiSU). 
No caso da UnB, no semestre 2014/1, houve total ocupação das vagas remanescentes do Enem (SiSU) 2014 pelos participantes inscritos na Lista de Espera, conforme mostra a Tabela 3.2.

Tabela 3.2 - Vagas para os cursos de Direito, Engenharia (Civil, Elétrica, Florestal e Mecânica), História, Matemática, Medicina e Pedagogia, remanescentes do Enem(SiSU), e ocupadas pelos alunos inscritos na Lista de espera da UnB, no primeiro semestre de 2014/1.

Vagas remanescentes do Enem (SiSU) no semestre 2014/1 nos cursos pesquisados
Ocupação das vagas remanescentes do Enem (SiSU) pela Lista de Espera

\begin{tabular}{cccc}
\hline $1^{\underline{a}}$ & $2^{\underline{a}}$ & $3^{\underline{a}}$ & $4^{\underline{a}}$ \\
chamada & chamada & chamada & chamada
\end{tabular}

\begin{tabular}{lccccc} 
Direito & 17 & 9 & 8 & - & - \\
Engenharia Civil & 4 & 4 & - & - & - \\
Engenharia Elétrica & 6 & 3 & 1 & 2 & - \\
Engenharia Mecânica & 5 & 2 & 3 & - & \\
Engenharia Florestal & 8 & 2 & 1 & 1 & 4 \\
História (Bacharelado) & 9 & 4 & 2 & 2 & 1 \\
História (Licenciatura) & 9 & 3 & 6 & - & - \\
Matemática((Bacharelado) & 2 & 2 & - & - & - \\
Matemática(Licenciatura) & 7 & 7 & - & - & - \\
Medicina & 3 & 1 & 2 & - & - \\
Pedagogia & 15 & 2 & 1 & & \\
\hline
\end{tabular}

Para os cursos de Engenharia Civil e Matemática (Licenciatura e Bacharelado), o preenchimento total das vagas remanescentes ocorreu na primeira chamada e no caso dos cursos de Engenharia Florestal e História (Bacharelado) foram necessárias quatro chamadas. Os resultados do presente trabalho não consideraram a base de dados das vagas remanescentes. Entretanto, o caminhar da pesquisa nos leva a sugerir outras investigações a fim de identificar o perfil regional e socioeconômico dos ocupantes das vagas remanescentes do Enem (SiSU). 


\subsubsection{Mobilidade regional dos estudantes}

$\mathrm{Na}$ segunda parte do delineamento do perfil dos alunos pesquisados, elaborou-se a Tabela 3.3, que apresenta a frequência e porcentagem de alunos residentes ou não no Distrito Federal, antes do seu ingresso na UnB, considerando o prestígio social dos cursos e a forma de ingresso.

Tabela 3.3 - Frequência e porcentagem de alunos ingressantes, nos cursos de alto prestígio social Direito, Engenharias (Civil, Elétrica, Florestal e Mecânica) e Medicina, e nos cursos de baixo prestigio social - História, Matemática e Pedagogia, considerando residência ou não no Distrito Federal, antes do ingresso na Universidade de Brasília e a forma de ingresso dos alunos.

\begin{tabular}{|c|c|c|c|c|}
\hline \multirow{3}{*}{$\begin{array}{l}\text { Residência antes } \\
\text { do ingresso na } \\
\text { UnB }\end{array}$} & \multicolumn{4}{|c|}{ Alto prestígio social } \\
\hline & \multicolumn{2}{|c|}{ Vestibular 2013/2 } & \multicolumn{2}{|c|}{ SiSU 2014} \\
\hline & Frequência & $\%$ & Frequência & $\%$ \\
\hline Distrito Federal & 229 & 83,3 & 57 & 60,6 \\
\hline Outras UFs & 46 & 16,7 & 37 & 39,3 \\
\hline \multirow[t]{4}{*}{ Total } & 275 & 100 & 94 & 100 \\
\hline & \multicolumn{4}{|c|}{ Baixo prestígio social } \\
\hline & \multicolumn{2}{|c|}{ Vestibular 2013/2 } & \multicolumn{2}{|c|}{ SiSU 2014} \\
\hline & Frequência & $\%$ & Frequência & $\%$ \\
\hline Distrito Federal & 218 & 92,8 & 47 & 88,7 \\
\hline Outras UFs & 17 & 7,2 & 06 & 11,3 \\
\hline Total & 235 & 100 & 53 & 100 \\
\hline
\end{tabular}

Analisando a Tabela 3.3, observou-se que nos cursos considerados de alto prestígio social, a porcentagem de alunos que residiam no Distrito Federal, antes do ingresso na UnB, foi maior que aqueles oriundos de outras UFs, nas duas formas de ingresso, com $83,3 \%$ de ingressantes pelo vestibular e $60,6 \%$ mediante Enem. Foi verificado que, no Enem, 39,3\%, dos alunos que ingressaram em cursos de alto prestígio social, residiam em outras UFs, mais do que o dobro dos alunos selecionados mediante Vestibular (16,7\%).

Para os cursos considerados de baixo prestígio social, não foi identificada acentuada diferença entre a porcentagem de alunos que residiam no DF, antes do ingresso na UnB, e os que são oriundos de outras UFs, comparando-se as duas formas de ingresso. Este resultado sugere que a adoção do Enem não tem favorecido a mobilidade acadêmica para realização dos cursos considerados de 
baixo prestígio social, avaliados neste estudo. Na tentativa de explicação deste fenômeno, buscou-se pesquisas abordando o tema no âmbito de outras instituições de educação superior.

$\mathrm{Na}$ Universidade Federal Fluminense, Hustana Vargas (2010) realizou estudo que auxilia no entendimento acerca das razões pelas quais a procura por alguns cursos é maior do que por outros. A socióloga identificou que as carreiras universitárias se diferenciam "pelo prestígio social que têm, pela oferta de empregos e pelos salários ou rendas que permitem auferir". A autora complementa que, no processo de escolha pelo curso superior, o indivíduo tende, inconscientemente, a preferir o que é possível, realizável e a descartar as impossibilidades.

Por meio das ideias de Bourdieu (1996), é possível consolidar a compreensão da relação entre escolha do curso superior e condição socioeconômica. Sua obra aponta que indivíduos oriundos de famílias bem aquinhoadas, que podem custear financeiramente suas despesas antes e durante o curso, parecem sentir-se mais estimulados a optar por cursos de alto prestígio social, e fora de seu domicílio, enquanto que aqueles de classe social mais baixa tendem a optar por cursos populares, menos concorridos e próximos de seus domicílios.

Na pesquisa de Setton (1999), as licenciaturas foram incluídas no grupo de cursos populares, por apresentarem como características a baixa concorrência, a pouca valorização das carreiras, a expectativa de baixos salários, e a carência de oportunidades de emprego em postos de elevado status ocupacional. Alunos interessados em licenciaturas, de forma geral, não se sentem motivados a migrar da sua região e enfrentar as possíveis adversidades oriundas da mudança de domicílio, optando por cursos nas UFs onde residem.

Gatti (2012), ao relatar pesquisa sobre atratividade dos cursos de licenciatura, destaca que as mudanças nos diversos setores da vida social, juntamente com as transformações nos sistemas educacionais, têm colocado em crise a identidade dos professores e abalado a atratividade de jovens pelas licenciaturas.

As dificuldades encontradas pelos professores para lidar com a massificação do ensino; com os problemas de indisciplina e de violência; com a falta de sentido da escolarização para os alunos e com a introdução de novas 
tecnologias de ensino, são apresentadas pela autora como fatores relacionados à decrescente atratividade da carreira pelos jovens.

Esses elementos devem ser considerados ao se discutir porque é menor o número de jovens que opta pelos cursos de licenciatura. Entretanto, o fator econômico parece se encontrar na base desse processo de desvalorização da carreira. Lüdke e Boing (2004) afirmam que o aspecto decisivo no processo de declínio da ocupação docente, está na questão do baixo salário e do que isso representa para a dignidade e respeito de uma categoria profissional. A percepção da docência como profissão menor e o sentimento de menos valia das licenciaturas podem explicar porque alunos interessados em licenciaturas, de forma geral, não se sentem motivados a migrar da sua região e enfrentar as possíveis adversidades oriundas da mudança de domicílio, optando por cursos nas UFs onde residem.

Corroborando este pensamento, Zago (2009), em pesquisa com estudantes de baixa renda na Universidade Federal do Paraná - UFPR, indica que a necessidade de mudar de cidade para realizar o curso superior acaba sendo, para muitos estudantes, um fator dificultador do acesso à educação superior, tendo em vista a impossibilidade de arcar com despesas inerentes a este processo e ao optarem por mudar de cidade e enfrentar as dificuldades, normalmente não escolhem cursar licenciaturas, pelo baixo retorno econômico e social dos cursos.

A figura do professor é vista socialmente de forma contraditória. Se por um lado temos vasta literatura que indica que ser professor não é nada atrativo, por outro temos evidências numéricas do expressivo aumento no número de ingressos em licenciaturas no que tange às Universidades Federais.

Em trabalho recente, Nunes (2015) investigou os motivos de escolha da profissão de professor, e contrariamente aos estudos que demonstram falta de atratividade para as licenciaturas, o pesquisador observou que nos últimos anos, houve expressivo aumento no número de ingressantes nestes cursos nas IFES. Aponta que no ano de 2009 a taxa de crescimento de ingressantes em licenciaturas nas instituições públicas, em relação ao ano anterior, foi de aproximadamente $44 \%$, e no ano de 2010 de $51 \%$ em relação a 2009 , perfazendo aumento de $117 \%$ em apenas dois anos. 
Relatório sobre a profissão docente no Brasil, publicado pela UNESCO em 2004, sugere que os cursos de licenciatura representavam uma possibilidade de mobilidade social para famílias com pouca ou nenhuma escolaridade. Segundo o documento, constitui-se fator de distinção e ascensão social a indivíduos oriundos de famílias de pouca ou nenhuma escolaridade, o acesso a um curso superior, "mesmo" que seja em cursos de licenciatura. Tartuce et al. (2010) acrescentam que a carreira docente apresenta alguma possibilidade de acesso a trabalho por meio de um "curso de formação considerado como acessível" (TARTUCE et al., 2010, p. 451).

Para entender melhor a relação entre mobilidade regional dos estudantes para a UnB e prestígio e atratividade dos cursos, a Tabela 3.4 apresenta a porcentagem de alunos que residiam no Distrito Federal antes do ingresso na UnB, e de alunos que migraram de outras Unidades da Federação, considerando cada curso selecionado neste estudo e a forma de ingresso dos alunos.

Tabela 3.4 - Porcentagem de alunos que residiam no Distrito Federal antes do ingresso na Universidade de Brasília, e de alunos que migraram de outras Unidades Federativas (UFs), conforme curso e forma de ingresso (Vestibular 2013/2 e SiSU 2014/1).

\begin{tabular}{llcccc}
\hline $\begin{array}{l}\text { Prestígio } \\
\text { social }\end{array}$ & Curso & \multicolumn{2}{c}{$\begin{array}{c}\text { Distrito Federal } \\
\text { (\%) }\end{array}$} & \multicolumn{2}{c}{ Outras UFs (\%) } \\
\cline { 3 - 6 } & & Vestibular & $\begin{array}{c}\text { Enem } \\
\text { (SiSU) }\end{array}$ & Vestibular & $\begin{array}{c}\text { Enem } \\
\text { Alto }\end{array}$ \\
\cline { 2 - 5 } & Direito & 78,9 & 60,0 & 21,1 & 40,0 \\
& Engenharia Civil & 94,7 & 46,1 & 5,3 & 53,8 \\
& Engenharia Elétrica & 92,3 & 100,0 & 7,7 & - \\
& Engenharia Mecânica & 75,6 & 50,0 & 24,4 & 50,0 \\
& Engenharia Florestal & 79,6 & 73,3 & 20,4 & 26,6 \\
\multirow{3}{*}{ Baixo } & Medicina & 84,4 & 36,3 & 15,6 & 54,5 \\
& História (Bacharelado) & 86,0 & 88,8 & 14,0 & 11,1 \\
& História (Licenciatura) & 97,7 & 90,9 & 2,3 & 9,9 \\
& Matemática (Bacharelado) & 93,3 & 88,9 & 6,7 & 11,1 \\
& Matemática (Licenciatura) & 88,6 & 88,9 & 11,4 & 11,1 \\
& Pedagogia & 94,9 & 87,5 & 5,1 & 12,5 \\
\hline
\end{tabular}

Analisando a Tabela, verifica-se que para o vestibular, o curso que teve maior porcentagem de selecionados que residiam no DF antes do ingresso na UnB foi História - Licenciatura (97,7\%), e o que possuiu mais migrantes de outras UFs foi o curso de Engenharia Mecânica (24,4\%). Essa primeira análise aponta uma diferença, em termos relativos, dos dois tipos de ingresso, no quesito mobilidade 
regional, pois nos cursos de alto prestígio social houve maior ingresso de alunos de outras UFs, pelo Enem (SiSU), se comparado ao ingresso mediante vestibular.

Para o Enem (SiSU), o curso que teve maior porcentagem de selecionados que residiam no DF antes do ingresso na UnB foi Engenharia Elétrica (100\%), seguido de História Licenciatura, com 90,9\% e Matemática - Licenciatura e Bacharelado, ambos com $88,9 \%$ de ingressantes. Identificou-se também, que para o curso de Medicina, a porcentagem de alunos oriundos de outras Unidades da Federação foi de 54,5\% no Enem (SiSU), e de 15,6\% no Vestibular, seguido de Engenharia Civil, com 53,8\% ingressantes para o Enem (SiSU) e 5,3\% para o Vestibular. Para cursos considerados de baixo prestígio, não se percebeu relevante diferença entre a forma de ingresso dos alunos que residiam em outras Unidades da Federação.

O Gráfico 3.1 ilustra a proporção de alunos que residiam no DF antes do ingresso na UnB, e de alunos oriundos de outras UFs, que ingressaram em cursos considerados de alto prestígio - Direito, Engenharia (Civil, Elétrica, Mecânica e Florestal) e Medicina mediante Vestibular 2013/2 ou Enem (SisU) 2014/1.

Gráfico 3.1 - Proporção de alunos que residiam no Distrito Federal antes do ingresso na Universidade de Brasília, e de alunos oriundos de outras Unidades Federativas, conforme a forma de ingresso (Vestibular 2013/2 e Enem 2014/1) em cursos de alto prestígio social.

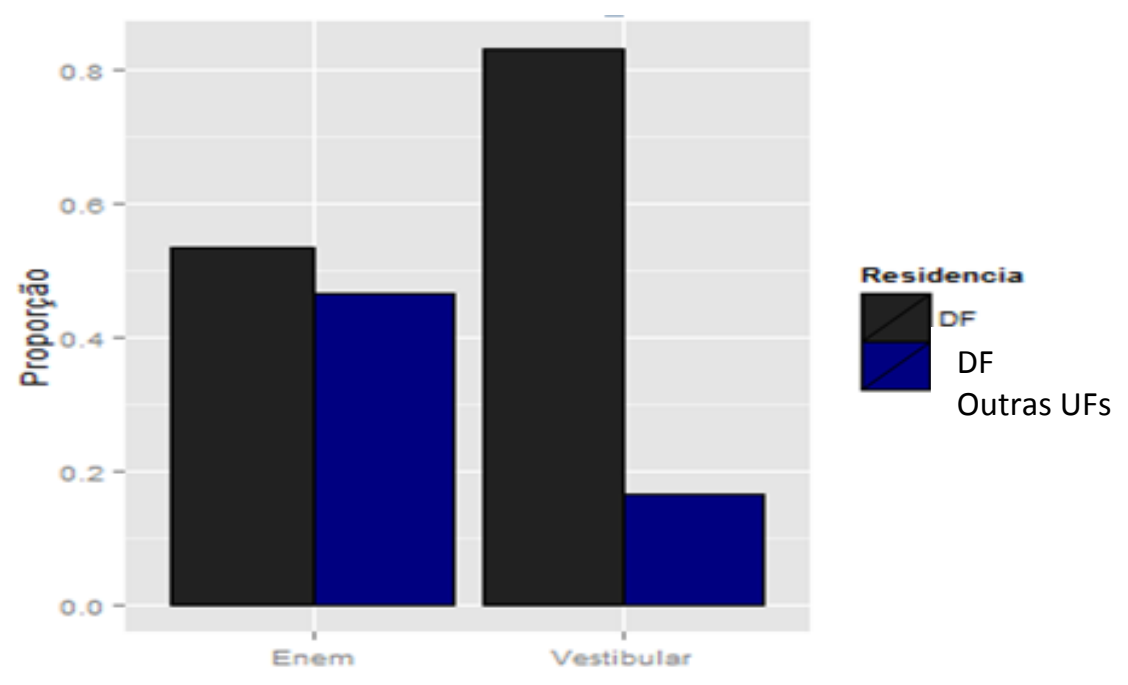

Para uma análise inferencial, foi realizado teste de diferença de proporção, com as seguintes hipóteses: 
$\mathrm{H}_{0}$ : A proporção de aprovados que residem em outras UFs é igual para os dois tipos de ingresso $\left(p_{1}=p_{2}\right)$;

$\mathrm{H}_{1}$ : A proporção de aprovados que residem em outras UFs é diferente para os dois tipos de ingresso $\left(p_{1} \neq p_{2}\right)$.

Com o $p$-valor encontrado $(0,001)$, em nível de significância de $5 \%$, rejeita-se a hipótese nula, ou seja, constatou-se diferença significativa entre as proporções de estudantes que residiam em outras UFs, segundo o tipo de ingresso, apontando que para os cursos considerados de alto prestígio social, a adoção do SiSU pela UnB aumentou o número de aprovados de outros estados.

O Gráfico 3.2 ilustra a proporção de alunos que residiam no Distrito Federal antes do ingresso na UnB, e de alunos oriundos de outras UFs, que ingressaram nos cursos de baixo prestígio social pesquisados, segundo forma de ingresso.

Gráfico 3.2 - Proporção de alunos que residiam no Distrito Federal (DF) antes do ingresso na UnB, e de alunos oriundos de outras UFs, segundo forma de ingresso,em cursos de baixo prestígio social.

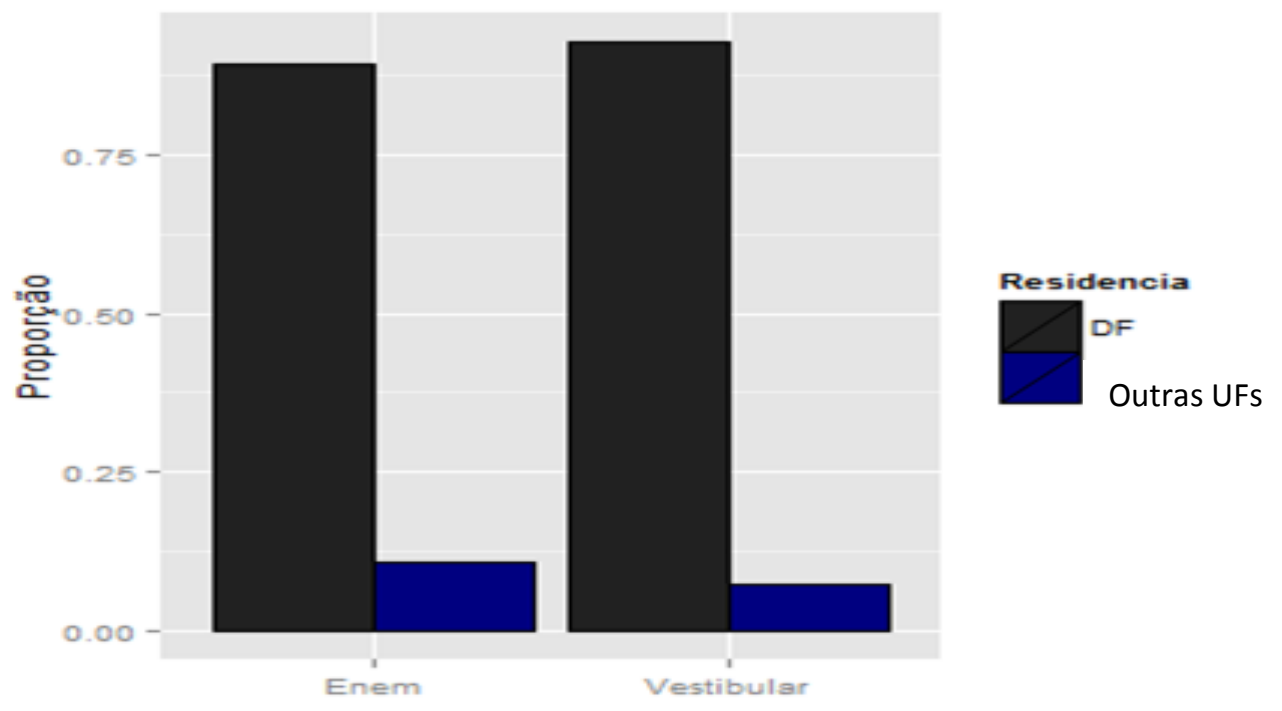

Para a análise inferencial, foram testadas as seguintes hipóteses:

$\mathrm{H}_{0}$ : A proporção de aprovados que residem em outras UFs é igual para os dois tipos de ingresso $\left(p_{1}=p_{2}\right)$;

$H_{1}$ : A proporção de aprovados que residem em outras UFs é diferente para os dois tipos de ingresso $\left(p_{1} \neq p_{2}\right)$. 
Com o p-valor encontrado $(0,55)$ não se rejeita a hipótese nula, ou seja, não existem evidências que comprovem que a diferença entre as proporções para o grupo de alunos de cursos de baixo prestígio social seja significante.

Um dado que merece destaque é o fato de que as UFs mais ricas têm predominado na exportação de alunos para outros estados. Ostermann et al. (2012), utilizando como parâmetro o PIB, estabeleceu que São Paulo, Rio de Janeiro, Minas Gerais, Rio Grande do Sul e Bahia são UFs ricas. Tal pesquisa apontou que a mobilidade acadêmica tem ocorrido com prevalência de sujeitos oriundos, em sua maioria, da cidade de São Paulo, tendência confirmada pelo levantamento realizado pelo MEC (2013), que demonstrou a migração de alunos de estados mais ricos para aqueles com menor PIB, ao apontar que, mais de $70 \%$ dos ocupantes das vagas oferecidas pelo SiSU, para o curso de medicina, naquele ano, migraram para os estados do Acre, Amazonas, Roraima, Mato Grosso e Paraná.

A Tabela 3.5 apresenta de forma detalhada a distribuição do número de alunos que ingressaram na UnB mediante Enem (SiSU) 2014/1, considerando a UF de origem.

Tabela 3.5 - Número de ingressantes mediante Enem (SiSU) - semestre 2014/1, nos cursos de Direito, Engenharia (Civil, Elétrica, Florestal e Mecânica), História, Matemática, Medicina e Pedagogia da UnB, considerando sua UF de origem.

\begin{tabular}{lccccccc}
\hline UF de origem & Dir. & Eng. $^{\mathbf{1}}$ & Med. & Hist. $^{2}$ & Mat. $^{3}$ & Ped. $^{\text {Total }}$ \\
\hline São Paulo & 4 & 0 & 1 & 1 & 0 & 1 & 07 \\
Rio Grande do Sul & 0 & 1 & 0 & 0 & 0 & 0 & 01 \\
Minas Gerais & 1 & 0 & 0 & 0 & 0 & 1 & 02 \\
Bahia & 1 & 1 & 1 & 0 & 0 & 0 & 03 \\
Santa Catarina & 0 & 0 & 0 & 1 & 0 & 0 & 01 \\
Espírito Santo & 1 & 0 & 1 & 0 & 0 & 0 & 01 \\
Goiás & 4 & 9 & 2 & 0 & 2 & 0 & 17 \\
Sergipe & 2 & 0 & 0 & 0 & 0 & 0 & 02 \\
Ceará & 1 & 0 & 0 & 0 & 0 & 0 & 01 \\
Pará & 0 & 2 & 0 & 0 & 0 & 0 & 02 \\
Mato Grosso & 0 & 1 & 0 & 0 & 0 & 0 & 01 \\
Maranhão & 0 & 1 & 1 & 0 & 0 & 0 & 02 \\
Tocantins & 0 & 0 & 1 & 0 & 0 & 0 & 01 \\
Rondônia & 1 & 0 & 0 & 0 & 0 & 0 & 01 \\
Amapá & 0 & 1 & 0 & 0 & 0 & 0 & 01 \\
Total & 15 & 16 & 6 & 2 & 2 & 2 & 43 \\
& & & & & & & \\
\hline
\end{tabular}


Observou-se que nesta forma de ingresso, no semestre 2014/1, a maioria dos ingressantes oriundos de outras UFs, é proveniente dos Estados de Goiás (17) e São Paulo (07). Salienta-se que dos 17 alunos oriundos de Goiás, seis residiam em Águas Lindas, Novo Gama, Valparaízo de Goiás e Santo Antônio do Descoberto, cidades que embora localizadas em Goiás, pela proximidade com o DF, possibilitam que as pessoas que lá residem, trabalhem e estudem no DF, retornando a seus domicílios diariamente. Diante desta particularidade, este estudo descaracteriza seu status de migrantes. Porém, há que se considerar que ainda assim, o estado de Goiás mantêm-se como a principal UF exportadora de estudantes para a Universidade de Brasília.

\subsubsection{Tipo de escola cursada no ensino médio}

Para uma primeira abordagem sobre a categoria tipo de escola que os estudantes predominantemente cursaram o ensino médio (pública ou privada), foram calculadas as frequências e porcentagens de alunos para cada tipo de ingresso, levando-se também em consideração o prestígio social dos cursos, conforme apresentado na Tabela 3.6:

Tabela 3.6 - Frequência e porcentagem de alunos que ingressaram na Universidade de Brasília, nos cursos considerados de alto prestígio social - Direito, Engenharia (Civil, Elétrica, Florestal e Mecânica) e Medicina, e nos cursos de baixo prestígio social - História, Matemática e Pedagogia, conforme o tipo de escola cursada no ensino médio (pública ou privada) e a forma de ingresso.

\begin{tabular}{|c|c|c|c|c|}
\hline \multirow{3}{*}{$\begin{array}{l}\text { Tipo de } \\
\text { Escola }\end{array}$} & \multicolumn{4}{|c|}{ Alto prestígio social } \\
\hline & \multicolumn{2}{|c|}{ Vestibular 2013/2 } & \multicolumn{2}{|c|}{ Enem (SiSU) 2014/1 } \\
\hline & Frequência & $\%$ & Frequência & $\%$ \\
\hline Privada & 351 & 68,8 & 82 & 57,3 \\
\hline Pública & 159 & 31,2 & 61 & 42,7 \\
\hline \multirow[t]{4}{*}{ Total } & 510 & 100 & 143 & 100 \\
\hline & \multicolumn{4}{|c|}{ Baixo prestígio social } \\
\hline & \multicolumn{2}{|c|}{ Vestibular 2013/2 } & \multicolumn{2}{|c|}{ Enem (SiSU) 2014/1 } \\
\hline & Frequência & $\%$ & Frequência & $\%$ \\
\hline Privada & 231 & 84,0 & 53 & 59,6 \\
\hline Pública & 44 & 16,0 & 36 & 40,4 \\
\hline Total & 275 & 100 & 89 & 100 \\
\hline
\end{tabular}


Os resultados apresentados apontam que, independente do prestígio social do curso no qual está matriculado e da forma de ingresso, a maior parte dos alunos selecionados tanto pelo vestibular 2013/2 quanto pelo Enem (SiSU) 2014, cursou o ensino médio em escolas privadas. Uma análise preliminiar dos números da Tabela 3.6, nos leva a acreditar que a adoção do Enem pela UnB propiciou um incremento de ingressantes oriundos de escolas públicas, nos cursos pesquisados. Entretanto, se levarmos em conta que em 2013 a UnB reservava 12,5\% de suas vagas para cotistas sociais e em 2014 esse percentual foi 25\%, não é possível afirmar com exatidão, que houve maior percentual de ingresso de alunos oriundos de escolas públicas selecionados via Enem (Sisu).

Para uma reflexão sobre este assunto, pode-se recorrer mais uma vez a Bourdieu (1996), que com sua visão crítica, fundamentou a ideia de que as desigualdades sociais se manifestam não apenas no acesso ao ensino superior em geral, mas nas escolhas entre diferentes percursos no interior desse nível de ensino. Essa seria, conforme o autor, uma "forma mais oculta de desigualdade". Os estudantes de origem mais modesta e oriundos de escolas públicas, seriam afetados por uma "restrição de escolha", concentrando-se nos cursos de menor prestígio social, em detrimento de opções mais concorridas e fora de sua realidade.

Nos debates que abordam os impactos do Enem nas políticas públicas da educação básica e no acesso à educação superior, os teóricos que criticam o exame, argumentam que trata-se de um processo classificatório como qualquer vestibular tradicional, que revela as disparidades da qualidade entre as escolas públicas e privadas do ensino médio (BARROS, 2014). Zago (2009) corrobora com este pensamento, e afirma que as desvantagens que os alunos da escola pública têm nos processos seletivos para ingresso em IFES são um grave problema, em razão da "baixa qualidade da educação que receberam". É como se o mesmo certificado escolar tivesse valor distinto, dependendo da categoria administrativa da escola ( se pública ou privada). Palazzo \& Gomes (2012) ao criticar o ensino médio público argumentam que não se trata de afirmar a qualidade de um sistema (privado) em detrimento do outro (público), mas sim de uma constatação pragmática que leva em consideração o baixo desempenho das escolas públicas frente às privadas.

Em uma perspectiva positiva, Haddad (2008) considera que é possível criar um novo paradigma, em que a escola pública de ensino médio tenha tanta ou mais qualidade que a particular, tornando o acesso às Instituições superiores, sobretudo 
as públicas, mais equânime. Para tanto, o teórico afirma que é necessário maior e melhor investimento na educação básica, por pelo menos uma geração, uma vez que na educação os frutos não se colhem em meses, mas a longo prazo. Esse investimento passa pela valorização dos professores da rede pública, por meio de capacitação contínua, pagamento de salários dignos, além da disponibiização de maior aporte de recursos para as escolas públicas e o acompanhamento de sua aplicação.

Ainda analisando a variável tipo de escola cursada no ensino médio, e buscando apresentar os dados de forma mais detalhada, elaborou-se a Tabela 3.7, na qual é apresentada a porcentagem de ingressantes, em cada um dos cursos pesquisados, levando-se em consideração o prestígio social dos cursos e a forma de ingresso dos alunos.

Tabela 3.7 - Porcentagem de alunos que ingressaram na Universidade de Brasília, nos cursos pesquisados, considerando o prestígio social dos cursos, tipo de escola cursada no ensino médio e forma e semestre de ingresso (Vestibular - 2013/2 e Enem (SiSU) - 2014/1).

\begin{tabular}{|c|c|c|c|c|}
\hline \multirow[t]{3}{*}{ Curso } & \multicolumn{4}{|c|}{ Alto prestígio social } \\
\hline & \multicolumn{2}{|c|}{ Privada (\%) } & \multicolumn{2}{|c|}{ Publica (\%) } \\
\hline & Vestibular & $\begin{array}{l}\text { Enem } \\
\text { (SiSU) }\end{array}$ & Vestibular & $\begin{array}{l}\text { Enem } \\
\text { (SiSU) }\end{array}$ \\
\hline Direito & 85,6 & 44,4 & 14,4 & 55,6 \\
\hline Engenharia Civil & 74,3 & 71,4 & 25,7 & 28,6 \\
\hline Engenharia Elétrica & 85,7 & 50,0 & 14,3 & 50,0 \\
\hline Engenharia Mecânica & 74,3 & 80,0 & 25,7 & 20,0 \\
\hline Engenharia Florestal & 82,9 & 60,0 & 17,1 & 40,0 \\
\hline Medicina & 99,0 & 70,0 & 1,0 & 30,0 \\
\hline \multirow[t]{4}{*}{ Total } & 83,8 & 62,6 & 16,2 & 37,3 \\
\hline & \multicolumn{4}{|c|}{ Baixo prestígio social } \\
\hline & \multicolumn{2}{|c|}{ Privada (\%) } & \multicolumn{2}{|c|}{ Publica (\%) } \\
\hline & Vestibular & $\begin{array}{l}\text { Enem } \\
\text { (SiSU) }\end{array}$ & Vestibular & $\begin{array}{l}\text { Enem } \\
\text { (SiSU) }\end{array}$ \\
\hline História - (Bacharelado) & 80,0 & 40,0 & 20,0 & 60,0 \\
\hline História (Licenciatura) & 65,7 & 22,2 & 34,3 & 77,8 \\
\hline Matemática (Bacharelado) & 50,0 & 44,4 & 50,0 & 55,6 \\
\hline Matemática (Licenciatura) & 32,3 & 70,0 & 67,7 & 30,0 \\
\hline Pedagogia & 42,2 & 73,7 & 57,8 & 26,3 \\
\hline Total & 54,0 & 50,0 & 45,9 & 49,9 \\
\hline
\end{tabular}

Verifica-se que no caso do ingresso mediante vestibular, exceto para os cursos de Matemática (Licenciatura) e Pedagogia, houve maior ingresso de alunos provenientes do ensino médio privado, com maior porcentagem no curso de 
Medicina, (99,0\%), seguido de Engenharia Elétrica (85,7\%), Direito (85,6\%), Engenharia Florestal (82,9\%) e História-Bacharelado (80\%). Com relação ao ingresso por intermédio do Enem (SiSU), observou-se alta porcentagem de ingressantes advindos de escolas privadas nos cursos de Engenharia Mecânica (80\%), seguido de Engenharia Civil $(71,4 \%)$ e Pedagogia (73,7\%). Nessa forma de ingresso, chama atenção o fato dos cursos de Medicina, considerado de alto prestígio social, e Matemática, categorizado como de baixo prestígio social, ter a mesma porcentagem de ingressantes $(70 \%)$ que realizaram o ensino médio em escolas privadas. A análise da Tabela 3.6 nos leva a concluir que para a maior parte dos cursos pesquisados, especialmente naqueles de alto prestígio social, mantêmse a prevalência de alunos advindos das escolas privadas.

Zago (2009), ao estudar o acesso à Universidade Federal de Santa Catarina (UFSC) por parte de estudantes de camadas populares e oriundos de escolas públicas, identificou que seu ingresso ocorre, majoritariamente, em cursos de menor concorrência e baixo prestígio social. Diferentemente do que o presente estudo, assim como o de Zago (2009) demonstraram, o último Relatório de mapeamento da vida econômica, social e cultural dos estudantes das IFES brasileiras, encomendado pela ANDIFES à FONAPRACE (2012), considerou que os estudantes das instituições federais não são em sua maioria, oriundos de escolas privadas.

A conclusão do documento pode nos remeter ao conceito de resiliência educacional, termo cunhado por Silva (2003), para denominar a capacidade que determinados indivíduos pobres e oriundos de escolas públicas possuem de superar as adversidades e acessar cursos de alto prestígio. Visto por outro ângulo, o resultado deste estudo traz à tona fenômeno que surgiu após a instituição da Lei de Cotas Sociais, e vem ganhando espaço no cenário educacional do ensino médio brasileiro: pais que até a conclusão do ensino fundamental, mantêm seus filhos em escolas privadas, ao chegar o período de cursarem o ensino médio, os transferem para a escola pública, com a finalidade de que usufruam do direito às cotas sociais $e$ concorram às vagas nos melhores cursos e melhores universidades, em condição de vantagem com os que estudaram sempre neste tipo de escola.

A Lei foi celebrada pelos movimentos sociais como um marco no combate às desigualdades de um sistema educacional fragmentado, seletivo e dualista, tendo em vista seu objetivo de minimizar as diferenças na condição de acesso à educação superior. Todavia, o uso de artifício visando a burlagem deste dispositivo legal pode 
comprometer a factibilidade do seu objetivo de democratização do acesso à educação superior.

\subsubsection{Renda familiar}

Para analisar o quesito renda familiar, inicialmente, as informações foram agrupadas em quatro faixas de renda e uma categoria "não sei" e apresentadas em frequência e porcentagem, conforme a Tabela 3.8.

Tabela 3.7 - Frequência e porcentagem de ingressantes nos cursos de Direito, Engenharia (Civil, Elétrica, Florestal e Mecânica), História, Matemática e Pedagogia, da Universidade de Brasília, mediante vestibular no semestre 2013/2 ou pelo Enem (SiSU), no semestre 2014/1, conforme faixa de renda familiar informada.

\begin{tabular}{|c|c|c|c|c|}
\hline \multirow[t]{2}{*}{ Renda familiar $^{1}$} & \multicolumn{2}{|c|}{ Vestibular } & \multicolumn{2}{|c|}{ Enem (SiSU) } \\
\hline & Frequência & Porcentagem & Frequência & Porcentagem \\
\hline$<3$ & 69 & 13,5 & 32 & 22,1 \\
\hline 3 a 10 & 163 & 32,0 & 45 & 31,0 \\
\hline 11 a 20 & 95 & 18,7 & 29 & 20,0 \\
\hline$>20$ & 116 & 22,7 & 39 & 26,9 \\
\hline Não sei & 67 & 13,1 & * & - \\
\hline Total & 510 & 100 & 145 & 100 \\
\hline
\end{tabular}

De acordo com a Tabela 3.7, para o ingresso mediante vestibular, apenas $13,5 \%$ dos respondentes informaram renda familiar menor que três salários mínimos, enquanto que $22,1 \%$ de alunos ingressantes por meio do Enem (SiSU) declararam renda familiar nesta faixa, com percentual próximo aos valores observados nas demais categorias de renda para esta forma de ingresso.

Foi verificado ainda que o maior percentual de renda familiar dos alunos ingressantes nos cursos pesquisados encontra-se na faixa de três a dez salários mínimos, tanto no caso dos ingressantes mediante vestibular (32\%) quanto via Enem-SiSU, (31\%). Tendo em vista a baixa variação encontrada entre as faixas de renda familiar informadas, julgou-se pertinente a elaboração da Tabela 3.9, de forma a analisar detatalhadamente esta variação, considerando cada curso incluido na presente pesquisa. 
Tabela 3.9 - Renda familiar, em porcentagem, dos ingressantes na Universidade de Brasília, mediante Vestibular, no semestre 2013/2, e via Enem (SiSU), no semestre 2014/1, nos cursos de Direito, Engenharia (Civil, Elétrica, Mecânica, Florestal), História (Bacharelado e Licenciatura), Matemárica (Bacharelado e Licenciatura), Medicina e Pedagogia.

\begin{tabular}{|c|c|c|c|c|}
\hline \multirow[t]{2}{*}{ Curso } & \multicolumn{4}{|c|}{ Renda familiar ${ }^{1} \%$ - Vestibular } \\
\hline & $<3$ & 3 a 10 & 11 a 20 & $>20$ \\
\hline Direito & 4,80 & 28,9 & 21,5 & 33,7 \\
\hline Engenharia Civil & 0,0 & 25,8 & 17,1 & 37,1 \\
\hline Engenharia Elétrica & 2,9 & 22,9 & 20,0 & 48,6 \\
\hline Engenharia Mecânica & 5,8 & 31,4 & 22,9 & 31,4 \\
\hline Engenharia Florestal & 5,8 & 40,0 & 8,6 & 28,6 \\
\hline História (Bacharelado) & 14,3 & 17,2 & 28,6 & 14,3 \\
\hline História (Licenciatura) & 8,6 & 37,2 & 14,3 & 17,1 \\
\hline Matemática (Bacharelado) & 12,6 & 43,8 & 12,5 & 12,5 \\
\hline Matemática (Licenciatura) & 32,3 & 32,3 & 25,8 & 6,5 \\
\hline Medicina & 3,2 & 19,4 & 35,5 & 19,4 \\
\hline \multirow[t]{3}{*}{ Pedagogia } & 35,2 & 41,2 & 9,8 & 6,9 \\
\hline & \multicolumn{4}{|c|}{ Renda familiar \% - Enem (SiSU) } \\
\hline & $<3$ & 3 a 10 & 11 a 20 & $>20$ \\
\hline Direito & 20,0 & 31,4 & 17,1 & 31,4 \\
\hline Engenharia Civil & 0,0 & 35,7 & 28,6 & 35,7 \\
\hline Engenharia Elétrica & 0,0 & 40,0 & 10,0 & 50,0 \\
\hline Engenharia Mecânica & 10,0 & 40,0 & 30,0 & 20,0 \\
\hline Engenharia Florestal & 22,2 & 33,3 & 22,2 & 22,2 \\
\hline História (Bacharelado) & 30,0 & 30,0 & 20,0 & 20,0 \\
\hline História (Licenciatura) & 40,0 & 40,0 & 10,0 & 10,0 \\
\hline Matemática (Bacharelado) & 22,2 & 22,2 & 33,3 & 22,2 \\
\hline Matemática (Licenciatura) & 30,0 & 40,0 & 10,0 & 20,0 \\
\hline Medicina & 45,5 & 0,0 & 27,3 & 27,3 \\
\hline Pedagogia & 36,8 & 26,3 & 15,8 & 24,1 \\
\hline
\end{tabular}

No que se refere aos ingressantes mediante vestibular, a Tabela 3.9 mostra que os cursos nos quais o maior percentual de alunos informou pertencer a famílias com renda familiar acima de vinte salários mínimos, foram Engenharia Elétrica com (48,6\%), seguido de Engenharia Civil (37,1\%) e Direito (33,7\%).

Analisando os dados dos ingressantes mediante Enem (SiSU), observou-se que no curso de Engenharia Elétrica, 50\% dos alunos informaram ter renda familiar 
maior que vinte salários mínimos e nenhum estudante declarou renda inferior a três salários mínimos. Outra observação importante refere-se ao segundo maior percentual de renda, entre três e dez salários mínimos, verificado para os cursos de Engenharia Elétrica, Engenharia Mecânica, História Licenciatura e Matemárica Licenciatura, com $40 \%$.

Foi verificado que, com exceção dos cursos de Engenharia Civil e Elétrica, nos quais não foram observados ingressantes mediante Enem (SiSU) com renda familiar menor que três salários mínimos, para os demais cursos, se comparado ao vestibular, houve mudança na dinâmica de ingresso de alunos menos favorecidos economicamente, tanto para os cursos considerados de alto prestígio social quanto para os de baixo prestígio.

Para os cursos de Direito, Engenharia Florestal e Medicina, houve expressivo aumento da porcentagem de alunos que informaram renda inferior a três salários mínimos, no ingresso mediante Enem (SiSU). No caso do curso de Medicina, nesta faixa de renda, foram observados percentuais de $3,2 \%$ e $45,5 \%$ de alunos ingressantes mediante vestibular e Enem (SiSU), respectivamente.

Estes resultados, de certa forma, enfraquecem a histórica ideia de elitização da educação superior, defendida por Bourdieu (2010), segundo a qual as classes de menor renda ocupam cursos menos reconhecidos É importante lembrar que para qualquer variável analisada no presente estudo, a veracidade das informações é de inteira responsabilidade dos respondentes, e o receio da quebra de anonimato das informações prestadas aliado ao desconhecimento quanto à importância das respostas para subsidiar futuras pesquisas, pode levar alguns alunos a prestar informações inverídicas.

É notório, nos documentos oficiais, que a reformulação do Enem e a criação do SiSU, tem sua concepção calcada nos princípios de democratização do acesso, especialmente, para alunos menos favorecidos economicamente. Mesmo reconhecendo este princípio, com relação ao curso de Medicina, não era esperado no presente estudo a alta variação encontrada nos percentuais das duas formas de ingresso para alunos na menor faixa de renda familiar, principamente por ser o curso de Medicina historicamente reconhecido por seu alto prestígio social. Diante disto, as análises foram refeitas e os dados mantiveram-se inalterados. Considera-se que seria relevante a realização do cruzamento da variável renda com as variáveis origem regional e tipo de escola cursada, a fim de tornar mais sólidos os resultados 
encontrados nesta parte da análise. Entretanto, tal procedimento tornou-se iniviável tendo em vista que para manter a privacidade dos alunos, as bases de dados com os questionários, foram repassadas com supressão de seus nomes e CPFs.

Ristoff (2014) ao traçar o novo perfil socioeconômico do Estudante de Graduação, utilizando como principal fonte o questionário socioeconômico do Exame Nacional de Desempenho do Estudante (Enade), destacou que em todos os 47 cursos incluídos na sua pesquisa, percentual cada vez menor de estudantes oriundos de classes abastadas ingressa na educação superior, mesmo em cursos de alto prestígio social e consequentemente alta demanda. Para o teórico, este fato demonstra nitidamente os efeitos das políticas de inclusão implementadas pelo Estado nas últimas décadas.

Quanto à faixa de renda onde se situou maior número de respondentes na pesquisa realizada por Ristoff (2014), os resultados foram similares aos encontrados na presente pesquisa, na qual o maior contingente de estudantes informou renda familiar na faixa de 3 até de 10 salários mínimos, sugerindo que atualmente há maior contigente de estudantes dependentes de efetivas políticas de permanência, para se manterem no ambiente universitário.

\subsection{Análise qualitativa}

Segundo dados do Relatório obtido por intermédio da Diretoria de Desenvolvimento Social - 2014, o número de Participantes do Programa Assistência Estudantil - PPAES, matriculados no Campus Darcy Ribeiro da UnB é de 2.503. O questionário, objetivando verificar em que medida as ações implementadas pela UnB têm impactado na permanência dos alunos pesquisados, foi encaminhado, por meio eletrônico, para 236 alunos beneficiários, no semestre 2014/1, de políticas de permanência e matriculados no Campus Darcy Ribeiro, nos cursos de Direito, Engenharia (Civil, Elétrica, Florestal e Mecânica), História, Matemática, Medicina e Pedagogia.

Do total de questionários encaminhados, houve 38 devolutivas, conforme detalhado na Tabela 3.10. Sistematizadas as informações obtidas, as respostas a cada uma das 22 perguntas fechadas relativas à questão da permanência são apresentadas a seguir. 
Tabela 3.10 - Número de alunos matriculados nos cursos de Direito, Engenharia (Civil, Elétrica, Florestal e Mecânica), História, Matemárica e Medicina, beneficiários de políticas de permanência da Universidade de Brasília, no semestre 2014/1, e número de alunos respondentes ao questionário aplicado.

\begin{tabular}{lcc}
\hline Curso & $\begin{array}{c}\text { Solicitantes de políticas } \\
\text { de permanência }\end{array}$ & $\begin{array}{c}\text { Alunos respondentes ao } \\
\text { questionário }\end{array}$ \\
\hline Direito & 30 & 7 \\
Engenharia Civil & 19 & 3 \\
\hline Engenharia Elétrica & 19 & 8 \\
Engenharia Florestal & 62 & 2 \\
\hline Engenharia Mecânica & 14 & 5 \\
História & 40 & 7 \\
Matemática & 36 & 2 \\
Medicina & 11 & 1 \\
Pedagogia & 05 & 3 \\
Total & 236 & 38 \\
\hline
\end{tabular}

Numa análise preliminar da Tabela, causou estranheza o fato do maior número de solicitantes de políticas de permanência (62) ter sido verificado no curso de Engenharia Florestal, considerado, neste estudo, um curso de alto prestígio social e no qual apenas $5,8 \%$ dos alunos declarou renda familiar menor que três salários mínimos, conforme verificado na Tabela 3.9 da análise quantitativa.

Esta observação traz à tona a importância de um acompanhamento e avaliação eficaz dos processos de concessão das políticas de permanência, de forma a assegurar o seu acesso a pessoas que realmente atendam aos requisitos socioeconômicos.

De acordo com as diretrizes do PNAES, os critérios de seleção dos estudantes devem levar em conta o perfil socioeconômico dos alunos, além de critérios estabelecidos de acordo com a realidade de cada instituição. Podem participar dos programas de Assistência Estudantil da UnB os estudantes que possuem renda familiar per capita de até um salário mínimo e meio, não possuem formação acadêmica superior e atendam as condições do Decreto Presidencial $n^{\circ}$ 7.234/2010, que promove o PNAES. É evidente a importância dos programas de assistência estudantil voltados a estudantes de baixa renda, entretanto, para Marçal (2011) e Barretos (2003), a despeito dos grandes avanços obtidos a partir do PNAES, falta mais clareza quanto às metodologias de avaliação dos programas de assistência estudantil nos documentos oficiais. 
No primeiro bloco, objetivando traçar o perfil dos beneficiários das politicas de permanência da UnB, os alunos foram questionados sobre a sua forma de ingresso e curso, se residiam no Distrito Federal antes de ingressar na Universidade de Braília, nível de escolaridade do pai e da mãe e categoria administrativa da instituição onde cursaram o ensino médio (escola pública ou privada).

Tabela 3.11 - Frequência de respondentes ao questionário, matriculados nos cursos de Direito, Engenharia (Civil, Elétrica, Florestal e Mecânica), História, Matemática, Medicina e Pedagogia da Universidade de Brasília, conforme forma de ingresso (vestibular ou Enem) e residência, ou não, no Distrito Federal, antes do ingresso no curso.

\begin{tabular}{lc}
\hline Variáveis & Frequência \\
\hline Por qual forma você ingressou na UnB? & \\
Vestibular & 25 \\
Exame Nacional do Ensino Médio - Enem & 11 \\
Não respondeu & 02 \\
Total & 38 \\
Onde você morava antes de ingressar na & \\
Universidade de Brasília? & \\
No Distrito Federal & 25 \\
Em outra Unidade da Federação & 13 \\
Total & 38 \\
\hline
\end{tabular}

Quanto à forma de ingresso, 25 respondentes ingressaram mediante Vestibular e 11 por meio do Enem e 2 alunos não responderam a questão. Questionados sobre o local onde residiam antes de ingressar na UnB, 25 alunos informaram que residiam no Distrito Federal e 13 em outras UFs.

Existe um encadeamento entre escolaridade do pai e da mãe, nível socioeconômico e a procedência do Ensino Médio e acesso à educação superior, que ocorre da seguinte forma: pais que possuem baixa escolaridade situam-se em níveis socioeconômicos inferiores, matriculam seus filhos em escolas públicas e em função de seu baixo capital cultural, cobram pouco de seus filhos, em termos de desempenho escolar. Esta associação de fatores, que normalmente os coloca em desvantagem em relação aos egressos do ensino particular e provenientes de famílias com elevado capital cultural, repercute no desempenho destes alunos nos processos seletivos.

Como bem lembra Azevedo (1964) e Teixeira (1989), o simples fato de frequentar a escola no Brasil sempre foi sinônimo de privilégio e distinção social durante boa parte da nossa história republicana. A variável nível de escolaridade do 
pai e da mãe é utilizada nos estudos sobre acesso à educação superior, para explicar, em parte, a trajetória escolar positiva ou negativa dos fillhos.

O reconhecimento dessa relação foi constatado por diversos autores, a exemplo de Ostermann (2013), que afirma que, filhos de pais mais aquinhonhados e com elevado nível educacional tendem a desenvolver trajetórias escolares mais longas e prestigiadas, enquanto filhos de pais pobres e com menor nível educacional costumam ter trajetórias escolares mais curtas e desprestigiadas. A Tabela 3.11 apresenta os dados referentes à escolaridade dos pais e mães dos alunos constantes da amostra, beneficiários com algum tipo de política de permanência da UnB, no semestre 2014/1.

Tabela 3.12 - Nível de escolaridade do pai e da mãe dos alunos respondentes ao questionário, matriculados nos cursos de Direito, Engenharia (Civil, Elétrica, Florestal e Mecânica), História, Matemática, Medicina e Pedagogia,

\begin{tabular}{lc}
\hline Variáveis & Frequência \\
\hline Qual o nível de escolaridade de seu pai? & \\
Sem escolarização & 03 \\
\hline Fundamental incompleto & 12 \\
Fundamental Completo & 04 \\
Médio incompleto & 03 \\
\hline Médio Completo & 12 \\
Superior incompleto & 01 \\
Superior Completo & 02 \\
Especialização & 01 \\
\hline Total & 38 \\
Qual o nível de escolaridade da sua mãe? & \\
\hline Sem escolarização & 02 \\
Fundamental incompleto & 07 \\
Fundamental Completo & 02 \\
Médio incompleto & 03 \\
Médio Completo & 17 \\
Superior incompleto & 02 \\
Superior Completo & 03 \\
\hline Especialização & 02 \\
\hline Total & 38 \\
\hline
\end{tabular}

Analisando a primeira parte da tabela 3.11 , observa-se que três pais não possuem escolarização, mesmo número observado na soma dos pais que possuem formação superior ou realizaram especialização. Sobre o nível de escolaridade das 
mães, na segunda parte da tabela, verifica-se que duas não possuem escolarização, e cinco possuem curso superior ou especialização, demonstrando ligeira vantagem no percurso educacional em relação aos pais. Estes dados confirmam a tendência apontada por Baudelot e Establet (1992, apud MATTOS, 2011) quanto ao fato das mulheres alcançarem maior escolarização que os homens, na tentativa de diminuir a desigualdade de gênero, constatada, sobretudo na qualidade dos postos de trabalho ocupados por homens e mulheres.

Quando questionados sobre o tipo de escola onde cursaram o ensino médio (se escola pública ou privada) observou-se que a maioria dos alunos (27) é oriunda do ensino médio público e 8 respondentes cursaram este nível de ensino na escola privada, conforme observado no Tabela 3.13.

Tabela 3.13 - Frequência de alunos solicitantes de políticas permanênciada da Universidade de Brasília, matriculados nos cursos de Direito, Engenharia (Civil, Elétrica, Florestal e Mecânica), História, Matemática, Medicina e Pedagogia, considerando o tipo de escola cursada no ensino médio (pública ou privada).

\begin{tabular}{lc}
\hline Varíáveis & Frequência \\
\hline Onde você cursou o ensino médio? & \\
Parte na escola pública e parte na & 03 \\
escola privada & 27 \\
Na escola pública & 08 \\
Na escola privada & 38 \\
\hline Total & \\
\hline
\end{tabular}

Abordando este assunto, Alvarenga e Costa (2012) mencionam que os estudantes de escola pública são, ainda, em minoria na universidade, em virtude das dificuldades de acesso ao ensino público. Neste estudo, se retomarmos a Tabela 3.3 da análise quantitativa, pode-se confirmar essa tendência, sendo observado maior ingresso de estudantes que cursaram o ensino médio em escola privada, independente do prestígio social do curso e da forma de ingresso. No entanto, ao se considerar que os respondentes do questionário são, na quase totalidade, alunos beneficiários de políticas de permanência, era esperado maior frequência de alunos provenientes da esfera pública, tendo em vista a relação existente entre condição socioeconômica e acesso a educação privada.

No segundo bloco de questões, buscou-se levantar aspectos referentes a reprovações, trancamentos de disciplinas e riscos de desligamentos, são condições regimentais estabelecidas pelas instâncias superiores da instituição (Decanato e Câmara de Graduação), que influenciam no percurso acadêmico e conclusão do 
curso. Os Gráficos 3.5, A, B e C apresentam o número de respondentes ao questionário que tiveram reprovação $(A)$, realizaram trancamento de disciplina durante a realização do seu curso(B) e estiveram em condição de desligamento(C).

Gráfico 3.3 - Número de respondentes ao questionário, (A) que tiveram reprovação, (B) que realizaram trancamento de disciplina durante a realização do curso, e (C) que já estiveram em condição de desligamento.

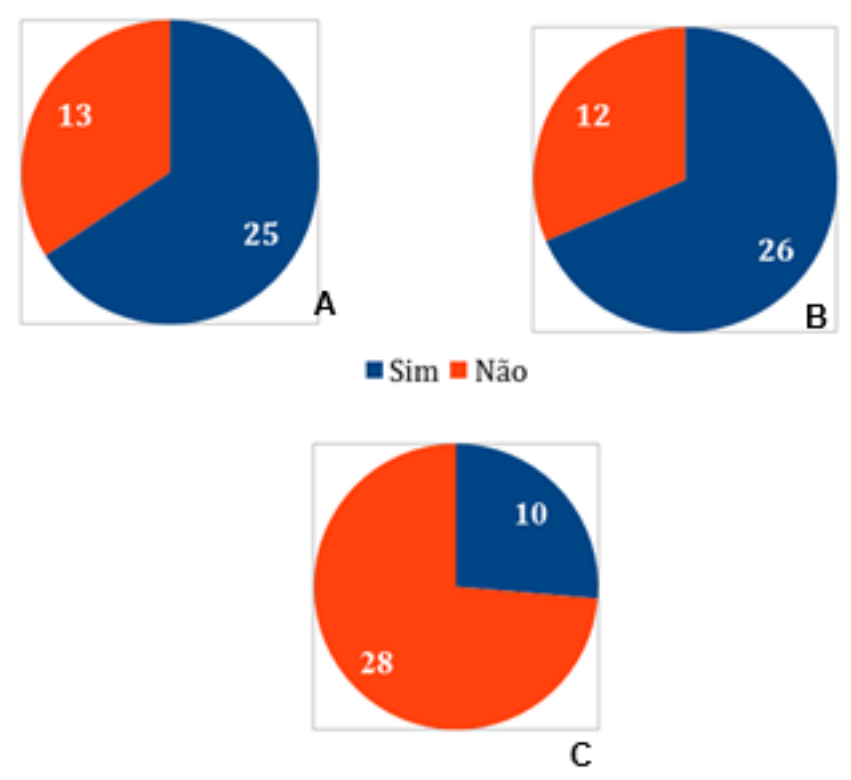

Considerando os gráficos relativos às respostas sobre estas questões, observa-se que dos 38 respondentes, 25 afirmaram ter sido reprovados em pelo menos uma disciplina (Gráfico 3.5-A). Ao discorrer sobre este assunto, o Manual do Aluno de Graduação da UnB (2014), documento elaborado pelo Decanato de Graduação/UnB e pela Secretaria de Assuntos Acadêmicos/UnB, prevê reprovação para o aluno que não alcança nota igual ou superior a MM (Médio - 5,0 a 6,9) e/ou não comparece a, pelo menos, $75 \%$ das atividades.

Sobre a realização de Trancamentos parciais de matrícula (TRs), instrumento concedido aos alunos, apenas uma vez em cada disciplina, e no prazo estipulado no calendário acadêmico, 26 alunos, afirmaram terem sido beneficiados por este processo (Gráfico 3.5-B).

Quanto ao risco de desligamento, ao qual o aluno é submetido se "...tiver duas reprovações na mesma disciplina obrigatória; II-não tiver sido aprovado em, pelo menos quatro disciplinas do seu curso, em dois períodos letivos regulares 
consecutivos; III- chegar ao último período letivo permitido no projeto pedagógico do seu curso, sem possibilidade de conclui-lo..." (UnB, 2014), dez alunos informaram que estiveram nesta condição(Gráfico 3.5-C)O fato da maior parte dos respondentes não ter sido submetido a risco de desligamentos, embora tenha tido reprovações e/ou TRs, pode ser atribuído ao acesso à políticas de permanência disponibilizadas pela instituição, suposição que poderá ser confirmada na resposta à pergunta aberta deste questionário.

As dificuldades acadêmicas de estudantes oriundos de camadas populares são comumente atribuídas aos seus antecendentes escolares, um fator relevante, sem dúvida, mas não o único. O que se observa, é que a trajetória universitária é influenciada por diversas variáveis contextuais, entre elas, a necessidade de trabalho, e consequentemente menor tempo de dedicação aos estudos.

Pesquisa realizada por Veloso e Almeida (2002), com foco na análise da evasão na Universidade Federal de Mato Grosso (UFMT), afirma que um dos motivos do desempenho insatisfatório ou mesmo do abandono de curso nas IFES, é a necessidade que muitos alunos têm, de conciliar trabalho e estudo e, não raro, a obrigação de contribuir com o sustento da família. Investigações mais aprofundadas sobre o peso dessas variáveis na trajetória acadêmica são necessárias, mas é indiscutível a importância da assistência estudantil, numa perspectiva de direito social, para garantir a igualdade não só de acesso, mas de permanência, aos estudantes das instituições de ensino superior públicas, contribuindo na prevenção e erradicação da retenção e da evasão, quando decorrentes de dificuldades socioeconômicas.

Existe um discurso social de que o curso universitário é condição sine qua non para a possibilidade de ascensão social, via carreira, e muitas famílias têm como meta e se esforçam ao máximo para que seus filhos atinjam esse patamar em sua escolaridade. Os respondentes ao questionário foram questionados se contam com o auxílio famíliar para manter-se na universidade, e se exercem algum tipo de atividade profissional, seja ou não remunerada. A Tabela 3.14, apresenta numericamente, suas respostas. 
Tabela 3.14 - Número de respondentes que recebem ou não auxílio financeiro da família para manter-se na Universidade de Brasília, e de alunos que realizam ou não atividade profissional remunerada.

\section{Variáveis}

Frequência

Você conta com o auxílio financeiro familiar para manter-se na UnB?

Sim

Não

Total
18

20

38

Você exerce alguma atividade profissional remunerada?

Não 20

Faço estágio remunerado

10

Sim. Trabalho no horário inverso das aulas

Total

08

38

Quanto ao recebimento de apoio financeiro de sua família, os dados da demonstram que $47,3 \%$ dos alunos contam com esta ajuda para manterem-se na Universidade, e 52,6\% não recebem auxílio financeiro. No que se refere ao exercício de atividade profissional remunerada, observou-se que 20 respondentes não exercem nenhum tipo de atividade, além do desempenho de suas atividades acadêmicas, e a minoria dos alunos (8), trabalham no horário inverso das aulas. $\mathrm{O}$ baixo número de estudantes que exerce atividade remunerada, encontrado neste estudo, pode ser atribuído à dificuldade que estes encontram, mesmo em cursos noturnos, como é o caso das licenciaturas, de matricular-se em disciplinas, em um único turno, necessitando abrir mão do trabalho para dispor do horário integral para dedicação ao curso. Quanto aos estágios remunerados, 10 alunos afirmaram realizálos, o que Rima (2008), considera positivo para o aluno, no âmbito social, e imprescindível sob o aspecto da vinculação entre a teoria e a prática na formação profissional.

No terceiro e último bloco de questões do questionário aplicado, foi solicitado aos alunos que informassem se eram beneficiários de alguma política oferecida pela instituição, e em caso positivo, qual (is). 
Tabela 3.15 - Número de alunos que são beneficiários de políticas de permanência disponibilizadas pela Universidade de Brasília e tipo de auxílio utilizado.

\begin{tabular}{lc}
\hline Variável & Frequência \\
\hline $\begin{array}{l}\text { Você é beneficiário de alguma política de permanência na } \\
\text { Universidade? }\end{array}$ \\
Sim & 34 \\
\hline Não & 04 \\
\hline Total & 38 \\
\hline Com qual (is) política de permanência você foi contemplado? & \\
Bolsa Permanência MEC & 04 \\
\hline Já solicitei, mas não fui contemplado & 01 \\
\hline Nunca solicitei & 01 \\
\hline Programa Auxílio Emergencial & 05 \\
\hline Programa Auxílio Socioeconômico & 24 \\
Programa Bolsa Alimentação & 30 \\
\hline Programa Moradia Estudantil da Graduação & 17 \\
\hline
\end{tabular}

Dos 38 respondentes, um afirmou nunca ter solicitado política de permanência na Universidade de Brasília, outro aluno afirmou ter solicitado, mas não ter sido contemplado (Tabela 3.14). A maior concentração de alunos contemplados por políticas de permanência foi observada nos Programas Auxílio Alimentação (30), Auxílio Socioeconômico, (24) e Auxílio Moradia estudantil (17), o que se justifica pelo fato destas políticas representarem os maiores gastos, especialmete numa cidade com elevado custo de vida, que é o caso de Brasília. É importante esclarecer que as normas da UnB referentes à concessão destas políticas permitem que o mesmo aluno seja beneficiário de duas ou mais políticas de permanência, concomitantemente.

Os auxílios da assistência estudantil inserem-se no conjunto de estratégias públicas de enfrentamento às desigualdades sociais e são ancoradas na transferência monetária aos seus beneficiários. Entretanto, são muitas vezes entendidas como favor direcionado apenas aos mais pobres. Esta errônea concepção deve-se, sobretudo, à forma como são colocadas pelo Estado aos sujeitos, como se fossem de fato, concessões ou privilégios, e não direitos. Entendese que as ações de Assistência Estudantil direcionadas pelo PNAES, devem ter 
como prioridade fundamental viabilizar a igualdade de oportunidades e contribuir para a melhoria do desempenho acadêmico dos alunos, além de agir, de modo preventivo, para minimizar as situações de evasão e retenção decorrentes da insuficiência de condições financeiras.

Os alunos foram questionados sobre o nível de satisfação com as políticas de permanência disponibilizadas pela UnB, e quanto a importância dessas ações para sua manutenção na universidade.

Gráfico 3.4 - Nível de satisfação de alunos beneficiários, no semestre 2014/1, por políticas de permanência disponibilizadas pela Universidade de Brasília.

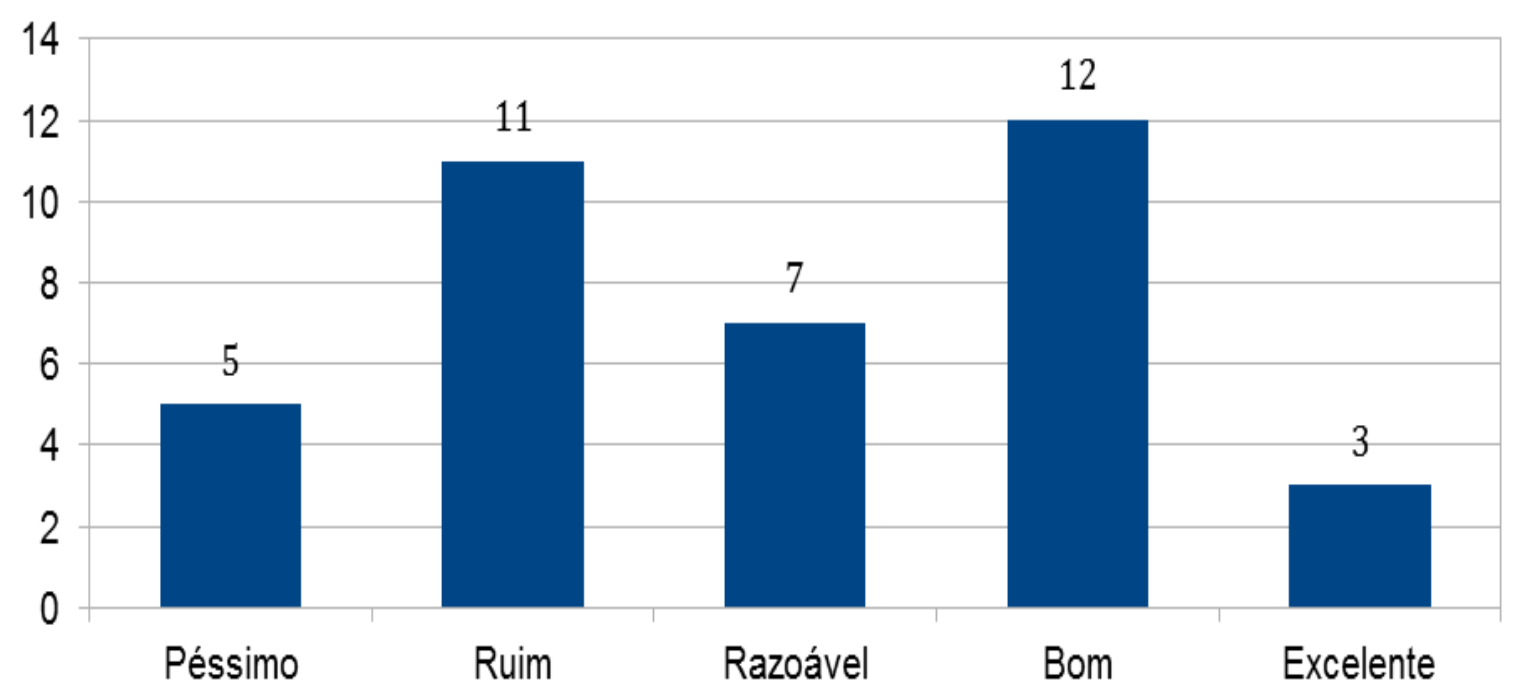

Gráfico 3.5 - Nível de importância das políticas de permanência oferecidas pela Universidade de Brasília, na percepção dos alunos por elas atendidos no semestre 2014/1.

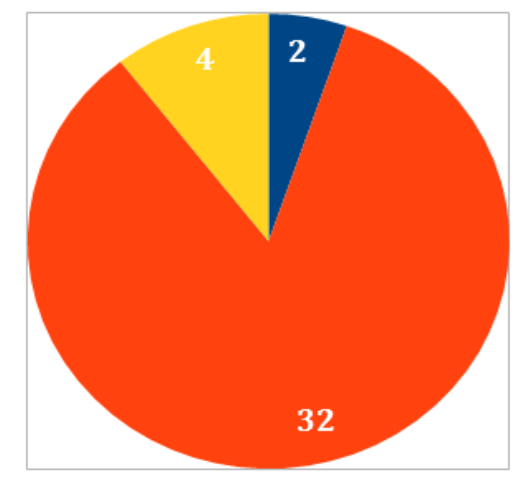

- Não faz muita diferença

- Muito. Sem ela (s)

dificilmente me manteria

Ajuda, mas não o bastante

As respostas aos questionamentos relacionados ao nível de satisfação com as políticas disponibilizadas e importância destas para a permanência dos alunos, 
mostraram certa incoerência, pois, ao responder à primeira pergunta (Gráfico 3.6), 15 alunos consideraram que as políticas de permanência proporcionam atendimento bom ou excelente, ao passo que 16 alunos consideraram o apoio péssimo, ou ruim e 7 estudantes afirmaram estar razoavelmente safisfeitos com 0 atendimento disponibilizado.

Todavia, ao responderem sobre a importância das ações para a sua manutenção na universidade, (Gráfico 3.7), 32 alunos alegaram que dificilmente conseguiriam manter-se sem o auxílio fornecido, e apenas seis alunos consideraram que o auxílio não faz diferença ou não ajuda suficientemente. Depreeende-se, portanto, que mesmo que não haja unanimidade quanto à excelência na oferta das políticas de permanência, estas garantem um mínimo de dignidade aos estudantes de baixa renda da Universidade de Brasília.

Finalizando o questionário, por meio da pergunta aberta, os alunos foram solicitados a sugerir possíveis melhorias nas políticas de permanência em curso e/ou indicar novas ações a serem implementadas. Para a análise desta questão, optou-se pela técnica de análise de conteúdo de Bardin (1977), que consiste no processamento das informações, transformando o conteúdo da comunicação por meio da aplicação de regras de categorização. Este tipo de análise permite a compreensão do fenômeno estudado ou conforme Bauer (2002), captar ou registrar eventos, valores, regras e normas socioculturamente compartilhadas, bem como a reconstrução de indicadores e cosmovisões, valores, atitudes, opiniões, preconceitos, e sua comparação entre grupos ou comunidades. A intenção foi debruçar-se sobre o conteúdo manifesto nas respostas dos alunos, e obter, por procedimentos sistemáticos e objetivos de descrição do conteúdo escrito, a sua percepção, sobre a questão das políticas de permanência.

Após a leitura, as respostas foram sistematizadas e agrupadas por semelhança, resultando em 09 unidades temáticas, que contemplam a categoria referente às melhorias nas políticas de assistência estudantil já implementadas pela UnB, ou sugestões de outras ações, na percepção dos alunos respondentes ao questionário, conforme é apresentado no Quadro 3.2. 
Quadro 3.2- Melhorias nas políticas de assistência estudantil já implementadas pela UnB, ou sugestões de outras ações, na percepção dos alunos respondentes ao questionário

\begin{tabular}{|c|c|c|c|}
\hline & Unidade Temática & Verbalização & Freq. \\
\hline 1 & Importância do auxílio & Sem o auxílio não conseguiria me manter. & 1 \\
\hline 2 & $\begin{array}{l}\text { Reajuste no auxílio financeiro } \\
\text { fornecido pela instituição }\end{array}$ & $\begin{array}{l}\text { Um reajuste no valor das bolsas auxiliaria - } \\
\text { Os valores deveriam ser atualizados - Seu } \\
\text { valor não é suficiente }-O \text { auxilio a } \\
\text { permanência deveria ser ampliado - Eles } \\
\text { forneciam um valor mensal para alimentação } \\
\text { para fins de semana.. }\end{array}$ & 5 \\
\hline 3 & Vagas na moradia estudantil & $\begin{array}{l}\text { Novos blocos de graduação poderiam ser } \\
\text { construídos -A abertura de mais vagas para } \\
\text { estudantes que moram no DF - O auxílio } \\
\text { moradia é limitado apenas para alunos que } \\
\text { moram fora do DF - Maior quantidade de } \\
\text { vagas para o programa moradia estudantil - } \\
\text { Moro em zona rural que é muito longe da UnB. }\end{array}$ & 5 \\
\hline 4 & Lentidão nos processos & $\begin{array}{l}\text { Mais rapidez na concessão das bolsas - } \\
\text { Editais deveriam sair o quanto antes- os } \\
\text { atrasos atrapalham muito- Vários atrasos- } \\
\text { Mais rapidez na concessão das bolsas- Os } \\
\text { editais deveriam sair o quanto antes- Os } \\
\text { atrasos atrapalham muito. }\end{array}$ & 7 \\
\hline 5 & $\begin{array}{l}\text { Auxílio para viagens } \\
\text { acadêmicas }\end{array}$ & Falta auxílio às viagens acadêmicas & 1 \\
\hline 6 & Apoio Acadêmico & $\begin{array}{l}\text { Alunos vindos de rede pública sofrem muitas } \\
\text { dificuldades de adaptação, acadêmicas } \\
\text { inclusive- Vejo a necessidade de auxiliar } \\
\text { alunos com dificuldades em disciplinas- rever } \\
\text { as condições para desligamento do curso- } \\
\text { Deveria existir um sistema de } \\
\text { acompanhamento dos alunos. }\end{array}$ & 4 \\
\hline 7 & $\begin{array}{l}\text { Maior controle na concessão } \\
\text { das bolsas }\end{array}$ & $\begin{array}{l}\text { Tem pessoas na UnB que recebem o auxílio e } \\
\text { não precisam tanto - Melhoria no sistema de } \\
\text { seleção de alunos beneficiários de bolsas de } \\
\text { auxílio. }\end{array}$ & 2 \\
\hline 8 & Assistência médica & $\begin{array}{l}\text { Acompanhamento social e psicológico - } \\
\text { suportes que vão além do recebimento de } \\
\text { bolsas, a exemplo do auxílio acadêmico e } \\
\text { do atendimento hospitalar-Convênio ou } \\
\text { projeto que pudesse oferecer um suporte } \\
\text { hospitalar- Suporte psíquico. }\end{array}$ & 4 \\
\hline \multirow[t]{2}{*}{09} & Divulgação dos programas & Melhor divulgação dos programas. & 1 \\
\hline & Total & & 33 \\
\hline
\end{tabular}


Após a categorização, agrupamento e análise das falas dos alunos, com vistas a identificar a importância que as políticas de permanência têm para a trajetória acadêmica dos alunos respondentes, evidenciou-se que o maior número de observações dos alunos (7), refere-se à lentidão do processo de seleção para acesso aos benefícios, bem como aos atrasos do pagamento das bolsas.

A segunda maior frequência de falas (5) refere-se à questão do reajuste do valor das bolsas, cujos valores não têm acompanhado o aumento do custo de vida. Com a mesma frequência (5) aparece o tema referente às vagas na moradia estudantil. Este gasto é tido juntamente com a alimentação, como um dos que mais impactam na manutenção dos alunos na universidade. A importância da moradia estudantil é ressaltada nas disposições legais atuais sobre a assistência ao estudante. No âmbito federal, o PNAES aponta a moradia estudantil como o principal item das ações de assistência estudantil.

É sabido que após o aluno de baixa renda ultrapassar a difícil barreira do ingresso em uma instituição pública fora do município onde mora, não raro defrontase com problemas de diversas ordens. Muitos não conseguem manter-se e acabam desistindo dos cursos, trazendo prejuízos de toda ordem para si mesmos e para o País. Estudos realizados em diversas IFES: a exemplo da Universidade Federal de Santa Maria (UFSM), Universidade de Brasília (UnB), Fundação Universidade Federal do Rio Grande (FURG), Universidade Federal de Pelotas (UFPel) e Universidade Federal de Uberlândia (UFU), demonstraram que os estudantes de baixa condição socioeconômica, que fazem parte de algum programa de apoio nessas instituições, não apresentam diferença no rendimento acadêmico ou até obtêm rendimento acadêmico superior aos colegas. (ANDIFES, 2007).

Fica explícito, portanto, que na percepção dos alunos, a oferta de ações com vistas à permanência na universidade, é essencial para que estudantes provenientes de classes não abastadas possam permanecer e concluir seus cursos com a qualidade almejada. Entretanto, a existência destas políticas por si só, não garante sua eficácia, pois a maioria dos alunos contemplados tem nestes auxílios, sua única fonte de manutenção, e o atraso nos pagamentos os leva a situações precárias de sobrevivência, que impactam sobremaneira na performance acadêmica. 
O valor do Auxílio Socioeconômico subsidiado pelo PNAES é de $\mathrm{R} \$ 465,00$. Quanto à Bolsa Permânencia mantida pelo MEC, o valor é de $R \$ 400,00$, unificado em todas as IFES do País. Vale lembrar que o custo de vida de Brasília é considerado o terceiro mais elevado do Brasil, segundo levantamento da Numbeo (2010), site que mede o custo de vida de todas as cidades do Brasil e exterior. Desta forma, o valor que seria suficiente para um aluno socioeconomicamente residente em outra UF, pode não ser para o estudante da UnB.

As verbalizações dos alunos confirmam o exposto por Pacheco e Ristoff (2004) quando mencionam que $25 \%$ dos potenciais alunos universitários são tão carentes, que mesmo com ensino superior sendo gratuito, não tem condições de se manter na instituição. Andriola (2011) complementa que: "a mobilidade acadêmica idealizada para os universitários da graduação, deve estar pautada em ações de assistência estudantil de maior monta e de envergadura nacional".

Embora o reduzido número de respondentes ao questionário tenha sido elemento limitador para esta parte da pesquisa, as ponderações feitas pelos respontes ao questionário, ratificam a ideia de que as políticas de permanência ofertadas pela UnB são percebidas pela maioria dos alunos respondentes, como um direito social e que a condição socioeconomica do aluno está diretamente relacionada ao desempenho e conclusão do seu curso de graduação. É relevante o desenvolvimento de outras pesquisas sobre essa temática, envolvendo um número maior de alunos e diversidade de cursos, bem como melhoria nas formas de avaliação, monitoramento e impacto das ações de permanência, a fim de atender por completo as demandas dos alunos. 


\section{CONCLUSÃO E CONSIDERAÇÕES FINAIS}

Este estudo objetivou verificar em que medida o Enem, a partir de sua reformulação ocorrida em 2009, tem contribuído para a democratização do acesso à educação superior, e de que forma as ações implementadas pela Universidade de Brasília tem favorecido a permanência dos seus alunos de graduação.

Foi proposto como primeiro objetivo específico, traçar o perfil socioeconômico dos 510 ingressantes nos cursos de Direito, Engenharia (Civil, Elétrica, Florestal e Mecânica), História, Matemática, Medicina e Pedagogia, mediante vestibular no semestre 2013/2 e dos 185 alunos ingressantes por intermédio do Enem (SiSU), no semestre 2014/1. Para tanto, levou-se em conta as variáveis origem regional dos alunos, categoria administrativa da instituição onde cursaram o ensino médio (se pública ou privada) e a renda familiar informada.

A aprovação da proposta de reformulação do Enem e sua vinculação ao SiSU teve como premissa promover a democratização da educação superior, por meio da mobilidade acadêmica, tendo como alvo, pelos menos na teoria, os estudantes de diferentes regiões do País, com baixo poder econômico. Buscou-se criar condições para que estes estudantes participassem do processo seletivo de todas as instituições públicas de educação superior, sem a barreira da distância geográfica, que normalmente, anda lado a lado com a barreira econômica.

O segundo objetivo específico do estudo foi investigar se houve alteração no perfil regional e socioeconômico dos alunos incluídos na pesquisa. Quanto à questão da origem regional, observou-se que a maioria dos ingressantes mediante vestibular residia no Distrito Federal anteriormente ao seu ingresso na UnB. Com a adesão da instituição ao Enem, houve real crescimento no número de ingressantes oriundos de outras UFs. Entretanto, esta migração foi mais expressiva nos cursos considerados de alto prestígio social (Direito, Engenharias e Medicina), nos quais se observou $39,3 \%$ de alunos oriundos de outras UFs, ao passo que, nos cursos de baixo prestigio social (História, Matemática e Pedagogia), foi verificada migração de apenas de $11,3 \%$. Depreende-se, portanto, que embora apresentem uma dinâmica de seleção envolta num discurso de igualdade no acesso à educação superior, a adoção do Enem e a utilização da plataforma SiSU não trouxeram significativa mudança no perfil do alunado dos cursos pesquisados, mantendo-se a lógica da 
seletividade social e a histórica característica meritocrática dos processos de seleção, propiciando mais e melhores possibilidades de acesso àqueles alunos oriundos de classes favorecidas economicamente. O discurso de concessão das mesmas oportunidades de acesso, desconsiderando as assimétricas condições regionais, sociais e econômicas, torna a propagada mobilidade acadêmica um discurso excludente, fortalecendo a desigualdade educacional.

A mobilidade é de fato assegurada a todos no momento de realização do exame. Entretanto, mesmo com a oportunidade de concorrerem a uma vaga em instituições distantes de suas regiões de moradia, os candidatos se deparam com o histórico quadro presente na educação superior brasileira: maior número de candidatos do que vagas, e consequente maior concorrência, que tornou-se ainda mais agressiva com a institucionalização da plataforma SiSu, criando um quadro de competição e ranqueamento entre as universidades, onde os alunos com maior capital cultural vão para as melhores e mais concorridas universidades, restando para os demais candidatos, as instituições menos reconhecidas e mais distantes dos grandes centros.

Ademais, o discurso de mobilidade estudantil apresentado na proposta de reformulação do exame mostra-se contraditório, ao se observar que os procedimentos burocráticos de confirmação da vaga pleiteada em instituições, a exemplo da UnB, não prevêem um instrumento de matrícula a distância ou pelo site do SiSU, exigindo a presença do interessado para tal confirmação. Algumas instituições estabelecem que o beneficiado venha confirmar presencialmente seu interesse pela vaga, o que pode ser fator importante no processo de redução do percentual de vagas ociosas. Mas se o selecionado não tem recursos para o deslocamento para a realização das provas, é provável que também não os tenha para confirmação da vaga. A alternativa seria nomear um procurador no Estado onde deseja estudar, possibilidade de que nem todos dispõem.

Seguindo o delineamento do perfil dos alunos, ao analisar a variável categoria administrativa da escola cursada, conclui-se que, independente do prestígio social dos cursos e da forma de ingresso, os alunos predominantemente cursaram o ensino médio em escolas privadas. Comparando-se as duas formas de ingresso percebe-se que após a adoção do Enem (SiSU) pela UnB, persiste a prevalência de estudantes oriundos da escola privada. 
No que se refere ao aspecto socioeconômico, o maior percentual de alunos, tanto no ingresso mediante vestibular, quanto pelo Enem (SiSU), informou renda familiar na faixa de 3 a 10 salários mínimos. A maior renda familiar (acima de 20 salários mínimos) foi informada pelos alunos matriculados nos cursos de Engenharia Elétrica e Engenharia Civil, e a menor renda familiar, (inferior a três salários mínimos), foi encontrada entre os alunos pertencentes aos cursos de Pedagogia e História (licenciatura).

Ao correlacionarmos as variáveis origem regional, tipo de escola cursada e renda familiar informada, com o objetivo de identificar se houve alteração no perfil regional e socioeconômico dos alunos da UnB, conclui-se que a adoção do Enem tem favorecido a migração de alunos de outras UFs, de forma mais expressiva, para os cursos de alto prestígio social, oriundos de escolas privadas e em sua maioria com renda famliar entre três e dez salários mínimos. Observa- se discreta evolução no quantitativo de ingressantes oriundos de escolas públicas e sobretudo, em cursos de baixo prestígio social, sugerindo, que a condição socioeconômica do indivíduo continua exercendo influência direta quanto ao lugar a ser ocupado pelo aluno dentro da universidade, desconstruindo a ideia de democratização do acesso.

Com relação à importância das ações oferecidas pela UnB, com vistas à permanência dos alunos por ela atendidos, bem como sobre sugestões dos respondentes quanto a mudanças, as respostas ao questionário nos permitem inferir que de forma geral, as políticas são consideradas fundamentais para a manutenção dos alunos na instituição. As críticas referem-se aos valores dos auxílios oferecidos, quantidade de bolsas e ao processo de gerenciamento na seleção para acesso as mesmas.

Ao problematizarmos a questão da democratização do acesso à educação superior, assume-se que a democratização da educação superior necessita ser configurada em dois aspectos: criar vagas nas instituições de ensino com vistas a abarcar maior número de estudantes desprestigiados economicamente e para além da expansão quantitativa, ampliar as ações de assistência aos estudantes. Se a democratização do acesso implica na expansão da rede pública, ampliando a oportunidade de ingresso de alunos socialmente carentes, a democratização da permanência envolve a manutenção e expansão dos programas de assistência (FONAPRACE, 1993). 
O discurso da oportunidade de concorrer em nível nacional, tão enfaticamente defendido pelos idealizadores da proposta de reformulação do Enem e a adoção do SiSU, cria uma aparente democratização do acesso, sem levar em consideração a realidade desigual no ensino médio brasileiro. Para exemplicar o quanto é irreal a isonomia de oportunidades prometidas pelo Enem,(SiSU) pode-se fazer uma analogia entre uma corrida de carros e o acesso à educação superior. Todos tem a possibilidade de largar do mesmo lugar, entretanto, os que chegam em primeiro, são os que se prepararam melhor e tem os melhores carros. Trazendo para o plano da educação superior, o Enem oferece a mesma condição para realização das provas, entretanto os que ingressam nos melhores cursos continuam sendo aqueles com melhor capital cultural, os demais, via-de-regra ficam pelo caminho, ou se contentam com cursos menos prestigiados.

É incoerente se pensar em um processo seletivo unificado num País onde qualitativamente o ensino médio encontra-se em níveis diferenciados. O documento norteador das reformulações do Enem (MEC/2009) expressa que o novo formato do exame traria um estreitamento da relação entre ensino médio e superior. Conclama as IFES a repensar o ensino médio, discutir a relação entre conteúdos exigidos para ingresso na educação superior e propõe uma reestruturação no sentido de qualificar os alunos do ensino médio para o ingresso na educação superior.

Whitaker e Fiamengue (2001) citam que os concorridos processos seletivos, diante de suas exigências e critérios, culminam por distanciar os alunos socialmente carentes da Universidade, não por falta de mérito, mas porque são em sua maioria provenientes de escolas públicas com ensino defasado.

O Enem uma política pública recente e dinâmica, em processo de consolidação, e por isto, merece ser acompanhada sistematicamente. O caminho percorrido nos últimos anos, em termos de expansão das oportunidades de acesso à educação superior, não pode ser negligenciado e a plena democratização do ingresso às IFES deve ser uma busca permanente, uma vez que os processos de desigualdade ainda impactam sobremaneira o ingresso ou o não ingresso a este nível de ensino.

As desigualdades sociais, que se refletem não só na perspectiva econômica, mas também na educacional, pressionam as universidades a indagarem e promoverem a indagação, sobre quais são as necessidades dos grupos e populações onde está inserida, como estas necessidades estão sendo (ou não) 
problematizadas e quais ações estão sendo tomadas para atendê-las. Algumas destas insituições, reconhecendo-se parte da realidade concreta da sociedade, e admitido que suas funções devem ser pensadas e trabalhadas levando-se em conta as exigências e a busca da melhoria das condições de vida daqueles que estão no seu entorno, tem implementado iniciativas objetivando contribuir para a democratização do acesso à educação superior, à parcelas menos favorecidas da população, por meio de projetos de extensão, que aproximam a escola pública da universidade

Na Universidade Federal Fluminense - UFF, alunos de escolas públicas recebem formação complementar com o envolvimento de estudantes dos cursos de licenciatura daquela instituição. O Estado de Pernambuco se destaca, com a implantação do Programa "Rumo à Universidade", uma parceria entre universidades públicas locais e a Secretaria de Educação do Estado, que promovem aulas nos finais de semana para alunos socioeconomicamente carentes, os quais recebem uma bolsa-auxílio. Outras universidades federais, a exemplo da Universidade de Santa Maria/RS - UFSM, Universidade Federal de Alagoas- - UFAL, Universidade Federal do Rio de Janeiro-UFRJ, Universidade Federal de Minas Gerais-UFMG, Universidade de São Paulo-USP, Universidade Federal da Bahia-UFBA, tem se destacado na oferta de cursos pré-vestibulares gratuitos, destinados a populações "marginalizadas".

No âmbito da UnB é reconhecida a preocupação no sentido de que maior número de atividades extensionistas sejam colocadas em prática, de maneira que seus alunos participem de projetos que se voltem para fora da universidade. Uma ação que merece destaque é o Programa Formação Integrada e Emancipadora de Acesso à Educação Superior - FORMANCIPA. Trata-se de Programa de democratização do acesso à educação superior, parceria entre o Serviço de Paz, Justiça e Não Violência do Pedregal - SERPAJUS e a UnB, e conforme o nome retrata, desenvolve um processo de formação integrada, emancipadora e gratuita a estudantes em fase final ou egressos do ensino médio no muncípio do Novo Gama GO.

O projeto é conduzido por estudantes de graduação da UnB, sob a coordenação e supervisão da UnB, do Dr. Erlando da Silva Rêses. A interdisciplinaridade ocupa lugar central neste projeto, onde as diferentes áreas do conhecimento interagem para o desenvolvimento das aulas, que acontecem sob a 
lógica de temas e conteúdos em diferentes níveis de complexidade e aprofundamento. O estudante beneficiário do projeto é estimulado a exercer o autodidatismo a partir dos elementos fundantes e centrais de cada área do conhecimento. As aulas são realizadas aos sábados, no período diurno.

Outra ação que merece ser destacada é o projeto desenvolvido pelo núcleo da UnB no Paranoá, denominado Centro de Cultura, Aprendizagem e Inovação Social - CAIS. Trata-se de novo conceito de centro universitário. Neste projeto, as atividades de ensino, pesquisa e extensão são oferecidas, mas o principal diferencial em relação às modalidades de campus e pólo universitário está no vínculo estabelecido com a comunidade local e suas demandas.

A UnB já desenvolve trabalhos na área da saúde, educação, do direito e da informática no Paranoá, mas segundo Ivan Carmargo, Reitor da instituição, a intenção deste projeto é produzir mais do que tem sido feito por meio das ações individuais de professores que atuam na região, é trazer institucional e fisicamente 0 prédio da UnB para este novo terreno", A proposta do CAIS é tornar-se protagonista na forma de atuação das universidades junto à população.

Finalizando este trabalho, dentro da perspectiva extensionista das ações acima mencionadas, apresenta-se, despretensiosamente, e a título de proposta, produto técnico de intervenção na realidade da instituição. Cabe mencionar que a proposta não tem a pretensão de constituir-se em manual, cartilha ou guia a ser seguido, busca apenas, apresentar a ideia de criação de um espaço privilegiado de socialização de saberes e de trocas de experiências, numa perspectiva de inclusão social e de formação cidadã, que visa contribuir, no âmbito da UnB, com a superação da lógica da exclusão social e educacional ainda tão presentes no acesso a seus cursos de graduação. 


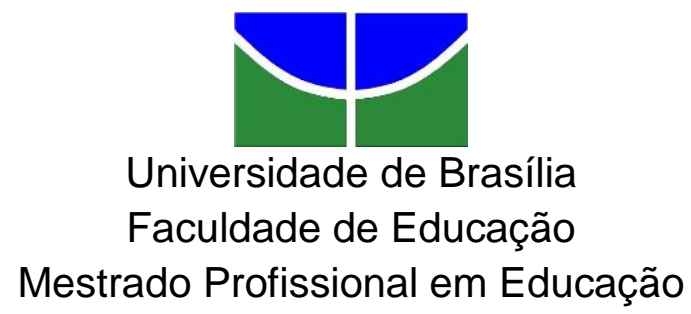

PRODUTO TÉCNICO

Vânia Maria Lourenço

Este produto integra a dissertação de mestrado intitulada "Limites e possibilidades do Enem no Processo de democratização do acesso à Educação superior brasileira". Figura como requisito parcial para obtenção do título de mestre em Educação, área de concentração: Gestão de Políticas Públicas e Sistemas Educacionais e constitui-se em proposta de programa, com vistas a colaborar na minimização das dificuldades dos alunos da rede pública, frente aos processos seletivos de acesso à educação superior.

\section{Justificativa}

Diante do compromisso social da Universidade, que segundo Wanderley (2005) é o de, entre outros, colaborar para a transformação da sociedade, responder aos interesses universais e atender aos setores carentes, democratizar o o acesso à educação superior significa ampliar o ingresso a este nível de ensino, a todos os membros da sociedade - independente da classe social, cor ou raça - processo que deve ocorrer concomitantemente à criação de estratégias que garantam condições dos alunos manterem seus estudos, sem haver perda de qualidade educacional (ZANDONÁ, 2005). Nesse aspecto, as ações de democratização trazem em seu escopo o desafio de ser uma nova resposta, socialmente aceita e conhecida, capaz de gerar mudança de paradigmas. 
Á medida que socializa seu conhecimento, a universidade tem a oportunidade de exercer seu compromisso social com a melhoria da qualidade de vida dos cidadãos. Isso remete a se pensar o fazer das instituições de ensino superior, dentro da tríade, ensino, pesquisa e extensão, princípios reconhecidamente intrínsecos às universidades brasileiras.

Baseado na concepção de que a democratização do acesso à educação superior enseja, antes de mais nada, o estabelecimento de ações que antecedem o momento do processo seletivo, e ainda, atendendo a uma das exigências para conclusão do Curso de Mestrado profissional em educação da Universidade de Brasília, apresenta-se a seguir proposta de curso, em forma de Produto Técnico.

A proposta envolve o planejamento e oferta de ação denominada Programa de Democratização do Acesso e da Permanência do aluno na Universidade de Brasília-PDAP/UnB e objetiva atender a dois públicos distintos:

Aos alunos matriculados ou oriundos do ensino médio público ou da escola privada, na condição de bolsistas, comprovadamente socioeconomicamente carentes. Visa capacitá-los gratuitamente na matriz curricular do Enem, auxiliandoos na preparação para os processos seletivos para ingresso em cursos superiores, em condições de igualdade com os candidatos das classes mais favorecidas e;

Aos graduandos matriculados na disciplina de Estágio Supervisionado dos cursos de licenciatura da Universidade de Brasília, selecionados mediante critérios socioeconomicos e participantes do Programa de Assistência Estudantil PPAES/UnB, proporcionando apoio financeiro para a manutenção, bem como a oportunidade de colocar em prática o conteúdo apreendido em sala de aula.

O Projeto será vinculado ao Decanato de Extensão da Universidade de Brasília - DEX/UnB e contará com a parceria do Decanato de Assuntos Comunitários - DAC/UnB, por intermédio da Diretoria de Desenvolvimento Social DDS/UnB. Propõe-se que as aulas do PDAP/UnB sejam ministradas por estes acadêmicos, promovendo a articulação entre a teoria adquirida em sala de aula e a prática, contribuindo para o processo de sua formação profissional, além de suprir parte da demanda do Estágio Supervisionado, enquanto exigência dos cursos de graduação. Além disto, em contrapartida à ministração das aulas, estes receberão bolsa estudantil, oriunda de recursos do Programa Nacional de Assistência 
Estudantil. PNAES e as horas ministradas serão contabilizadas na disciplina Estágio Supervisionado.

\section{Proposta de Programa}

Nome do Programa: Programa de Democratização do Acesso e da Permanência do aluno na Universidade de Brasília.- PPAD/UnB.

Divulgação do Projeto: Será realizada por meio de cartazes, visitas às escolas públicas de Ensino Médio, imprensa e sítio da UnB.

Carga Horária: O curso acompanhará o calendário semestral da UnB e cada graduando participante atuará no período correspondente à carga horária do Estágio Supervisionado. As aulas deverão ser ministradas de segunda a sexta-feira, em três turnos, de $7 \mathrm{~h} 30$ às $12 \mathrm{hs}$, de $13 \mathrm{~h} 30$ às $18 \mathrm{hs}$ e 19h às 22h40, e aos sábados, de 8 às $12 \mathrm{hs}$, com 50min de duração para cada aula.

Local das aulas: Experimentalmente, as aulas serão realizadas no Campus Darcy Ribeiro, em locais disponibilizados pela Prefeitura do Campus.

Número de vagas: As vagas serão definidas de acordo com o número de alunos matriculados na disciplina Estágio Supervisionado, interessados em participar do Programa.

Processo seletivo: O processo seletivo será divulgado por edital específico e realizado pela Diretoria de Desenvolvimento Social da UnB, em duas etapas: Poderão se inscrever-se candidatos que estejam cursando o terceiro ano do ensino médio público, e aqueles que já concluíram este nível de ensino.

A primeira etapa consiste na análise do questionário socioeconômico, anexo ao edital, que deverá ser preenchido integralmente pelo candidato, e documentação comprobatória da situação socioeconômica. Os candidatos selecionados nesta etapa, serão submetidos à entrevista. Alunos que tiverem 3 faltas injustificadas serão desligados do curso. Para sua substituição serão chamados rigorosamente os alunos constantes da lista de espera. 
Conteúdo programático: Será desenvolvido por professores doutores ou mestres, voluntários no Projeto, vinculados às distintas áreas de conhecimento da UnB. O material ficará disponível online, para acesso dos alunos.

Periodicamente, ocorrerão reuniões de caráter didático-pedagógico com a equipe de professores/as, a fim de planejamento das aulas, bem como dos recursos didático-pedagógicos a serem utilizados para o desenvolvimento das aulas.

\section{Objetivos do Programa}

a) Oferecer, gratuitamente, estudos sistematizados, baseados na matriz curricular do Enem, a estudantes socioeconomicamente carentes, oriundos de escolas públicas, propiciando condições para ingressarem na educação superior;

b) Orientar os alunos, quanto à escolha profissional, aspectos profissionais dos cursos oferecidos pela UnB e questões burocráticas que dizem respeito aos processos seletivos (editais, solicitação de isenção da taxa de inscrição, realização da inscrição);

c) Contribuir para a formação dos alunos da UnB, matriculado na disciplina Estágio Supervisionado, propiciando a associação da teoria apreendida em sala de aula, à prática, por meio da ministração das aulas;

d) Auxiliar na manutenção financeira do aluno da UnB, ministrante das aulas e participante do Programa de Assistência Social, por meio de concessão de bolsa permanência, com recursos PNAES.

\section{Concepção de aprendizagem}

Tendo em vista que atualmente o Enem figura como pré-requisito para ingresso nos diversos processos seletivos de instituições, sejam estas públicas ou privadas, o conteúdo programático do $\mathrm{PPAD} / \mathrm{UnB}$, terá por base as disciplinas exigidas no Exame. Além das aulas, durante sua realização, o Programa oferecerá monitorias, simulados, plantões, núcleo pedagógico de acompanhamento e monitoramento dos alunos.

É preciso destacar que o Programa pretende ir além da transmissão de conteúdos propedêuticos, promovendo uma aproximação entre os alunos do ensino médio e a universidade, além de possibilitar um processo de reflexão crítica, 
ampliação de seus horizontes conceituais, levando-os a reconhecerem-se como sujeitos autônomos, conscientes de seus direitos e deveres.

Serão utilizadas as metodologias de base sociocultural construtivista que fortaleçam o papel do aluno, focalizando o seu potencial para agir de forma ativa e responsiva na construção de seu processo de aprendizagem. Buscar-se-á promover espaços dialógicos em que o protagonismo, a confiança e a autonomia sejam evidenciados, tendo em vista o envolvimento do aluno em uma atividade bidirecional em que a construção do conhecimento seja efetiva e vivenciada. A proposta pedagógica está direcionada para a conscientização tanto dos alunos ingressantes no Programa quanto dos ministrantes das aulas, estimulando uma postura crítica em relação aos problemas sociais, econômicos e políticos e de em nosso país.

\section{Certificação}

Os alunos ministrantes das aulas receberão certificado de Extensão emitido pela Universidade de Brasília.

\section{Avaliação do Programa}

Ao final do semestre serão disponibilizados formulários de avaliação, a fim de que todos os segmentos envolvidos no Programa, tenham a oportunidade de apontar eventuais problemas ou falhas identificadas no decorrer do semestre, visando o seu a aprimoramento. 


\section{REFERÊNCIAS BIBLIOGRÁFICAS}

AFONSO, A. J. Avaliar a escola e a gestão escolar: elementos para uma reflexão crítica. In: ESTEBAN, Maria Teresa (Org.). Escola, currículo e avaliação. São Paulo: Cortez, p. 38-56, 2005.

ALMEIDA, W. Acesso à universidade pública brasileira: posições em disputa. Estudos de Sociologia, Pernambuco, v. 2, n. 18, ago. 2012. Disponível em: $<$ http://www.revista.ufpe.br/revsocio/index.php/revista/article/view/72/56>. Acesso em: 23 jun. 2014.

AMARAL, N.C. Expansão-avaliação-financiamento: tensões e desafios da vinculação na educação superior brasileira. In: MANCEBO, D.; SILVA JÚNIOR, J.R.; OLIVEIRA, J.F.; CATANI, A.M. (Orgs). Reforma da educação superior: cenários passados e contradições do presente. São Paulo: Xamã, 2009 , p. 29-33.

ANDRADE, C. Y. de et al. Acesso ao ensino superior no Brasil: equidade e desigualdade social. Disponível em: <http://www.revistaensinosuperior.unicamp.br/ >. Acesso em: 03 out. 2012.

ANDRIOLA, W.B. Doze motivos favoráveis à adoção do Exame Nacional do Ensino Médio (ENEM) pelas Instituições Federais de Ensino Superior (IFES). Ensaio: Aval. Pol.Públ.Educ, v. 19, n. 70, p. 107-25, 2011.

ASSIS, A. C.; SANABIO, M. T.; MAGALDI, C.A.; MACHADO, C. S. As Políticas de Assistência Estudantil: Experiências Comparadas em Universidades Públicas Brasileiras, Revista GUAL, Florianópolis, v.6, n.4, p.125-146, 2013. (Edição Especial).

AZEVEDO, J.M.L. O Estado, a política e a regulação do setor educacional no Brasil: uma abordagem histórica. In: FERREIRA, N.S.C.; AGUIAR, M.A. (orgs.). Gestão da educação: impasses, perspectivas e compromissos. São Paulo: Cortez, 2.ed., 2001. p.17-42.

BARBOSA, Renilce Miranda Cebalho. O Discurso do ENEM na democratização do acesso ao ensino superior: repetição ou deslocamentos Dissertação (Mestrado) - Universidade do Estado de Mato Grosso. Programa de Pós-Graduação em Linguística, 2013.

BARRETO, Walewska Faria A. O Programa de Bolsas de Manutenção Acadêmicacomo estratégia da política de assistência na UFPE. 2003. Dissertação (Mestrado em Serviço Social), Universidade Federal de Pernambuco, Recife, 2003.

BASTOS, A.P. B.L. Herdeiros ou sobreviventes. Mobilidade Social no Ensino Superior no Rio de Janeiro. Dissertação de Mestrado. IFICS/UFRJ, 2004 
BOBBIO, R. $O$ futuro da democracia: uma defesa das regras do jogo. 6 ed. São Paulo: Editora Paz e Terra, 1997. 151p. (Coleção pensamento Crítico, 63).

BORGES, J. L. G.; CARNIELLI, B. L. Educação e estratificação social no acesso à universidade pública. Cadernos de Pesquisa, v. 35, n.124, 2005.

BORGES, R.A. A interseccionalidade de gênero, raça e classe no Programa Ciência sem Fronteiras: um estudo sobre estudantes brasileiros com destino aos EUA. Dissertação (Mestrado Profissional em Educação), Universidade de Brasília, Brasília, 2014.

BOURDIEU, P. O novo capital Razões práticas - sobre a teoria da ação. Tradução Mariza Corrêa. São Paulo: Papirus, 1996. p. 35-52.

BOURDIEU, P. O poder simbólico. Rio de Janeiro: Bertrand Brasil, 2010. 313p.

BRASIL. Decreto № 7.234 de 19 de julho de 2010. Dispõe sobre o Programa Nacional de Assistência Estudantil - PNAES. Disponível em: <http://www.planalto.gov.br/ccivil_03/_Ato2007-2010/2010/Decreto/D7234.htm>. Acesso em 14 jan. 2016.

BRASIL. Ministério da Educação. Portaria № 807 de 18 de junho de 2010. Institui o Exame Nacional do Ensino Médio - ENEM como procedimento de avaliação.Disponível em: https://www.legisweb.com.br/legislacao/?id=227492. Acesso em: 16 jan. 2016.

BRASIL. Ministério da Educação. 2009. Proposta à Associação Nacional dos Dirigentes das Instituições Federais de Ensino Superior. Disponível em:http://portal.mec.gov.br/index.php?option=com_docman\&view=download\&alias=7 68-proposta-novovestibular1-pdf\&category_slug=documentos-pdf\&ltemid=30192. Acesso em: 11 jan. 2016.

BRASIL. Lei $N^{\circ} 10.172$, de 9 de janeiro de 2001. Aprova o Plano Nacional de Educação e dá outras providencias. Diário Oficial da União. Disponível em: <http://www.planalto.gov.br/ccivil_03/leis/leis_2001/l10172.htm>. Acesso em 16 jan. 2016.

CARDOSO, C. B. Efeitos da política de cotas na Universidade de Brasília: uma análise do rendimento e da evasão. 2008. 134 f. Dissertação (Mestrado em Educação).Universidade de Brasília, Brasília, 2008.

CARNEIRO, Moaci Alves. O nó do ensino médio. São Paulo: Vozes, 2012. 283 p. Rev. Bras. Educ. v.19 n.56, Rio de Janeiro, jan./mar. 2014

CATANI, A. M.; HEY, A. P.; GILIOLI, R. S. P. PROUNI: democratização do acesso às instituições de ensino superior? Educar em Revista, Curitiba, n. 28, p. 125-140, dez. 2006.

CATANI, A. M.; OLIVEIRA, J. F. Educação superior no Brasil: reestruturação e metamorfose das universidades públicas. Rio de Janeiro: Editora Vozes, 2002. 
CESPE. Universidade de Brasília. Programa de Avaliação Seriada - PAS. Disponível em: <http:www.cespe.unb.br/pas/principios/principiospas.htm>. Acesso em: 16 jun. 2014.

CHIZOTTI, A. Educação superior e o mercado de serviços educacionais. Revista ecurriculum, v.12, n. 1, p. 898-923, jan./abr. 2014

CISLAGHI, J. F. S.;SILVA, M. T. O Plano Nacional de Assistência Estudantil e o Reuni: ampliação de vagas versus garantia e permanência. SER Social, Brasília, v. 14, n. 31, p. 489-512, jul./dez. 2012.

COELHO, Maria Inês de Matos. Vinte anos de avaliação da educação básica no Brasil: aprendizagens e desafios. Ensaio: aval. pol.públ.Educ. Rio de Janeiro, v. 16, n.59, p.229-258, abr./jun.2008.

COELHO, E. C. As profissões imperiais. Rio de Janeiro: Record. 1999.

CORBUCCI, P.R. Avanços, limites e desafios das Políticas do MEC para a Educação Superior na Década de 1990: Ensino de Graduação. Texto para Discussão no 869, IPEA, mar. 2002.

COUTINHO, Carlos Nelson. Contra-corrente: ensaios sobre democracia e socialismo. São Paulo, Cortez, 2000

CUNHA, L. A.Universidade Temporã: O Ensino Superior da Colônia à Erade Vargas. Rio de Janeiro: Editora Civilização Brasileira S.A., 2007. 312p.

CUNHA, L. A. A nova reforma do ensino superior: a lógica reconstruída. In: TRINDADE, H.; BLANQUER, J.-M. (Org.). Os desafios da educação na América Latina. Petrópolis: Vozes, 2003.

CUNHA, L. A. Políticas para o ensino superior no Brasil: até onde irá a autonomia universitária? Educação \& Sociedade, Campinas, n. 55, ago. 1996.

CUNHA, L.A.A Expansão do Ensino Superior: Causas e consequências. Debate e Crítica, n.5 p.27-58.1975.

CIAVATTA, M. Formação Integrada: caminhos para a construção de uma escola para os que vivem do trabalho. In: PARANÁ. Secretaria de Estado da Educação. Ensino médio integrado a educação profissional: concepções e construções a partir da implantação na Rede Pública Estadual do Paraná. Curitiba, 2008.

DINIZ-PEREIRA, Júlio Emílio. O ovo ou a galinha: a crise da profissão docente e a aparente falta de perspectiva para a educação brasileira, Revista Brasileira de Estudos Pedagógicos, v. 92, n. 230, p. 34-51, jan./abr. 2011.

DUBET, F.A. escola e a exclusão. Cadernos de Pesquisa, São Paulo, n. 119, p. 2946, jul. 2003. 
DURHAM, E. R. A universidade e o ensino no Brasil: novos estudos. São Paulo: CEBRAP, 2002.

FERNANDES, A. M. Avaliação de programa social de acesso à educação superior: o novo ENEM na Universidade Federal de Lavras. 2013. 96 p. Dissertação (Mestrado em Administração Pública)-Universidade Federal de Lavras, Lavras, 2013.

FERREIRA, E. C. L. Identidade, raça e representação: narrativa de jovens que ingressaram na Universidade de Brasília pelo sistema de cotas raciais. 2009. 211 f. Tese (Doutorado) - Faculdade de Educação, Universidade de Brasília, Brasília, 2009.

Fórum Nacional de Pró-Reitores de Assuntos Comunitários e Estudantis (Fonaprace). Perfil Dos Estudantes De Graduação: IFES/2012. Disponível Em: $<$ http://www.Unb.Br/Administracao/Decanatos/Dac/Fonaprace/Index.Html>. Acesso Em: 12 De Nov. 2015.

GATTI, B. A. A construção da pesquisa em educação no Brasil. Brasília: Liber Livro, 2012.

GATTI, B. A; BARRETTO, E. S. de S. Professores do Brasil: impasses edesafios. Brasília: UNESCO, 2009. Disponível em: <http://unesdoc.unesco.org/images/0018/001846/184682por.pdf>. Acesso em: 14 jan. 2016.

GIL, A. C. Como elaborar projetos de pesquisa. 4.ed. São Paulo: Atlas, 2007.

GOMES, L. L. Z. O Novo ENEM em questionamento enquanto política focalizada de indução curricular e de democratização de acesso ao Ensino Superior. Iptan, São João Del Rei, v. 5, n. 2, p.1-15, maio 2013.

HERINGER, Rosana. Expansão do ensino superior no Brasil: acesso, diferenciação interna e políticas de inclusão. XI CONGRESSO LUSO AFROBRASILEIRO DE CIÊNCIAS SOCIAIS, Salvador, v. 1, n. 11, p.1-15, 07 ago. 2011.

HEY, A. P. Professora da USP questiona Enem como forma de democratização do acesso à universidade. In: Semana de conhecimento e cultura da UFMG. 2009. Disponível em: <www.ufmg.br/online/arquivos/013510.shtml>. Acesso em: 14 jan. 2016.

IBGE. Instituto Brasileiro de Geografia Estatística. Produto Interno Bruto dos municí́pios 2010-2013. Disponível em: www.ibge.gov.br/home/estatística/economia/pibmunicipios/2010_2013/default_xls. Acesso em 12 jan.2016.

LEFEBVRE, Henri. Sociologia de Marx. Rio de Janeiro: Forense-Universitária, 1979. 
LEHER, R. Educação no capitalismo dependente ou exclusão educacional? In: MENDONÇA, Sueli Guadalupe de Lima; SILVA, Vandeí Pinto da; MILLER, Stela (Org.). Marx, Gramsci e Vigotski: aproximações. 1ed. Araraquara; Marília: Junqueira \& Marin; Cultura Acadêmica, 2009, v. 1, p. 223-252.

LIMA, Paulo Gomes. Políticas de educação superior no Brasil na primeira década do século XXI: alguns cenários e leituras. Avaliação (Campinas) [online]. 2013, vol.18, n.1, pp. 85-105.

LIMA, K. R. R. Contrarreforma do Estado, Educação Superior e REUNI: a Expansão com Precariedade. Engrenagem, v. 2, p. 9-17, 2011.

LIMA. K. R. R. A reforma do Estado e da educação no governo Fernando Henrique Cardoso: o ENEM como mecanismo de consolidação da reforma. Tese de Doutorado. São Carlos: UFSCar, 2005.

LUKÁCS, György. Socialismo e democratização. Escritos políticos 1956-1971. Rio de Janeiro: Editora UFRJ, 2008.

MANCEBO, D. Reforma da Educação Superior: o debate sobre a igualdade no acesso. In: BITTAR, M.; OLIVEIRA, J. F. Educação superior no Brasil - 10 anos pós-LDB, 2008. (Coleção Inep 70 anos, v. 2).

MARÇAL, José Antonio. Política de Ação Afirmativa na Universidade Federal do Paraná e a formação de Intelectuais negros (as). 2011. Dissertação (Mestrado em Educação). Universidade Federa do Paraná. Curitiba, 195 p. 2011.

MARTINS, Antonio Carlos Pereira. Ensino superior no Brasil: da descoberta aos dias atuais. Acta Cir. Bras., v.17, suppl.3, p. 04-06, 2002.

MARTINS, C.B. A reforma universitária de 1968 e a aberturapara o ensino superior privado no Brasil. Educ. Soc., Campinas, v. 30, n. 106, p. 15-35, jan./abr. 2009.

MATTOS, V. Pós-graduação em tempos de precarização do trabalho: alongamento da escolaridade e alternativa ao desemprego. São Paulo: Xamã, 2011.

MAZZONETTO, C. V. O Enem como Política Pública de Avaliação: construção e ou (des)construção do currículo escolar. 2014. 173 f. Dissertação (Mestrado) - Curso de Mestrado em Educação, Universidade Regional Integrada do Alto Uruguai e das Missões, Frederico Westphalen, 2014.

MOEHLECKE, S. Ação afirmativa no ensino superior: entre a excelência e a justiça racial. Educação \& Sociedade, Campinas, v. 25, n. 88, p. 757-776, 2004.

NOGUEIRA, J. F. F. Reforma da educação superior no governo Lula: debate sobre ampliação e democratização do acesso. 2008. 197 f. Dissertação (Mestrado) Faculdade de Educação, Universidade de Brasília, Brasília, 2008. 
NUMBEO. Cost of living in Brasília. 2016.Disponível em:<http://www.numbeo.com/cost living/city result.jsp?country=Brazil\&city=Brasilia $>$. Acesso em: 22 jan. 2016.

NUNES,E. Profissionalização precoce, acesso restrito e futuro incerto: a universidade tem jeito? dados e tabelas estatísticas. [S.I.], 2009. Slides apresentados à Associação Brasileira de Educação (ABE), 22 de setembro de 2009. Disponível em: <http://www.observatoriouniversitario.org.br/dados_e_tabelas_estatisticas/profission alizacao_precoce.pdf>. Acesso em: 12 jan. 2016.

NÚÑEZ, I.B.; RAMALHO, B.L. Aprendendo com o Enem: reflexões para melhor se pensar o ensino e a aprendizagem das ciências naturais e da matemática. Brasilia: Liber Livro Editora, 2011.

OLIVEIRA, J. F. et al. Avaliação institucional: projetos de auto-avaliação e vinculação entre avaliação, gestão e financiamento. In: OLIVEIRA, J. F.; FONSECA, M.(orgs.). Avaliação institucional: sinais e práticas. São Paulo: Xamã, 2008.

OLIVEIRA, Junia; SARAPU, Paula. Quem paga a conta da cota? Estado de Minas, Belo Horizonte, 19 de Set. 2012. Caderno Gerais, p. 19 - 20.

OSTERMANN, C.J.H. C.; PINHEIRO, N. C. Pinheiro Enem e as políticas públicas para a Educação, 2012. Disponível em http://www.if.ufrgs.br/images/arquivos/noticias/enem-mobilidade.pdf, acesso em fev. 2015.

PERRONE, L. Metodi Quantitativi della Ricerca Sociale. Feltrinelli, Milão, 1977.

PINHEIRO, M.F. O Público e o Privado na Educação: um conflito fora de moda. In FÁVERO, (org). A educação nas Constituintes Brasileiras.

PIRES, A. P. Sobre algumas questões epistemológicas de uma metodologia geral para as ciências sociais. In: POUPART, J. et al. A pesquisa qualitativa: enfoques epistemológicos e metodológicos. Petrópolis -RJ: Vozes, 2008.

UNESCO. O Perfil Dos Professores Brasileiros: O Que Fazem, O Que Pensam, O Que Almejam.São Paulo: Moderna, 2004. Disponível em:

http://unesdoc.unesco.org/images/0013/001349/134925por.pdf acesso em novembro de 2015.

RISTOFF, Dilvo. O novo perfil do campus brasileiro: uma análise do perfil socioeconômico do estudante de graduação. Avaliação, Campinas; Sorocaba, SP, v. 19, n. 3, p. 723-747. nov. 2014.

RIBEIRO, S. C.; KLEIN, R. A divisão interna da universidade: posição social das carreiras,Educação e Seleção, n. 5, p. 29-36, jan./jun. 1982. 
RISTOFF, Dilvo. Educação Superior: Democratizando o acesso. Textos para Discussão. Inep/ MEC, 2006.

RISTOFF. D. O novo perfil do campus brasileiro: uma análise do perfil socioeconômico do estudante de graduação. Revista da Avaliação da Educação Superior, v.19, n. 3, 2014.

ROMANELLI, Otaíza de Oliveira. História da Educação no Brasil. Ed. Vozes: Petrópolis. RJ, 2005.

ROSA, Chaiane de Medeiros. Políticas públicas para a educação superior no governo Lula. In: Poíesis Pedagógica, Catalão - GO, v.11, n.1, p. 168 -188, jan/jun. 2013.

SAMPAIO, H.; LIMONGI, F.; TORRES, H. Equidade e heterogeneidade no ensino superior brasileiro. Brasília: INEP, 2000. (Documento de Trabalho).

SANTOS, J. Acesso à educação superior: a utilização do Enem/Sisu na Universidade Federal do Recôncavo da Bahia. 2014. 127 f. Dissertação (Mestrado) Curso de Mestrado em Educação, Salvador, 2014.

SANTOS FILHO, J. C. Dos. Pesquisa quantitativa versus pesquisa qualitativa: o desafio paradigmático. In: GAMBOA, S. S. Pesquisa educacional: quantidadequalidade. 6 ed. São Paulo: Cortez, 2007.

SERVAN-SCHREIBER. Jean Louis. A arte do tempo. Ensaio da ação. 4.ed. Tradução:Teresa Montero Otondo. Sâo Paulo. Cultura Ed. Associados. 1996.

SILVA, J. S. Caminhada de jovens pobres para a universidade. Rio de Janeiro: Sete Letras, 2003.

SETTON, M. G. J. A divisão interna do campo universitário: uma tentativa de classificação, Revista Brasileira de Estudos Pedagógicos, v. 80, n. 196, p. 451471, set./dez. 1999.

SGUISSARDI, Valdemar. Estudo diagnóstico da política de expansão da (e acesso à) educação superior no Brasil 2002-2012. EDITAL № 051/2014 SESu, PROJETO DE ORGANISMO INTERNACIONAL - OEI, PROJETO OEI/BRA/10/002. CNE: Brasília, 2015.

SILVEIRA, M. M.; MEDEIROS, M. R. Assistência Estudantil nas universidades federais brasileiras: um estudo sobre as políticas de permanência. In: Anais do salão internacional de ensino, pesquisa e extensão, Pelotas, v. 4, n. 2, p.150-170, maio 2012.

SOBRAL, D. T. \& OLIVEIRA, P. de G. Avaliação seriada versus Exame vestibular: Semelhanças e Diferenças entre Coortes no Curso de Medicina da Universidade de Brasília. Revista Brasileira de Educação Médica, Rio de Janeiro, v. 30, n. 3, p. 181-191, 2006. 
SOBRINHO, J. D.; BRITO, M. R. F. La educación superior en Brasil: principales tendencias y desafíos. Avaliação, Sorocaba, v. 13, n. 2, p. 487-507, jul. 2008.

SGUISSARD; SILVA JR, J.R. Novas Faces da Educação Superior no Brasil Reformas do Estado e Mudanças na produção. Bragança Paulista: EDUSF, 2001.

SOUZA, D. N.; BITTAR, M. Política de educação superior e os programas de permanência para universidades públicas - 2003-2010. Série Estudos: Periódico do Programa de Pós-Graduação em Educação da UCDB, Mato Grosso do Sul, n. 35, p.200-217, jan./ jun. 2013.

SOUSA, L. N. Serviço Social e a Política de Assistência Estudantil na UnB. Brasília: Ed. UnB, 2014.

TOLEDO, José Roberto de; SALDAÑA, Paulo; BURGARELLI, Rodrigo - O Estado de S. Paulo. Gasto com Fies cresce 13 vezes e chega a $\mathbf{R} \mathbf{1 3 , 4}$ bi, mas ritmo de matrículas cai. O Estado de S.Paulo. $15 \mathrm{fev}$. 2015. Extraído de <http://saopaulo.estadao.com.br/noticias/geral,gasto-com-fies-cresce-13-vezes-e-chega-a-r-134-bi-mas-ritmo-de-matriculas-cai-imp-,1634714>, Acesso em 1 abr 2016.

TARTUCE, G. L.B.P.; NUNES, M. M. R.; ALMEIDA, P. C. A. Alunos do ensino médio eatratividade da carreira docente no Brasil. Cadernos de Pesquisa, v.40, n. 140, p. 445-477.Maio/ago. 2010. Disponível em:

http://publicacoes.fcc.org.br/ojs/index.php/cp/article/viewFile/172/185 acesso em novembro de 2015.

TRAVITZKI, Rodrigo. ENEM: limites e possibilidades do Exame Nacional do Ensino Médio enquanto indicador de qualidade escolar. 2013. Tese (Doutorado em Educação) - Faculdade de Educação, São Paulo, 2013. Disponível em: $<$ http://www.teses.usp.br/teses/disponiveis/48/48134/tde-28062013-162014/>. Acesso em: 2016-01-18.

TROW, Martin. Reflexion on the Transition from Elite to Mass to Universal Acess: Forms and Phases of Higher Education in Modern Society Since WWII. Philip Altbach: International Handbook of Higher Education, 2005.

VARGAS, Hustana Maria; PAULA, Maria de Fátima Costa de. A inclusão do estudante-trabalhador e do trabalhador-estudante na educação superior: desafio público a ser enfrentado. Avaliação (Campinas), Sorocaba, v. 18, n. 2, p. 459-485, jul,2013.Disponívelem:<http://www.scielo.br/scielo.php?script=sci_arttext\&pid=S1414 $-40772013000200012 \&$ Ing=en\&nrm=iso >. Acesso em: 22 jan. 2016.

VELOSO; T C. M. A. Acesso nas Políticas da educação superior: dimensões e indicadores em questão. Avaliação, Campinas; Sorocaba, SP, v. 18, n. 3, p. 727747, nov. 2011

VARGAS, Hustana Maria. Sem perder a majestade: "profissões imperiais" no Brasil, Estudos de Sociologia, v. 15, n. 28, p. 107-124, 2010. 
VAIRINHOS, V. M. Elementos de probabilidade e estatística. Lisboa: Universidade Aberta, 1996.

VIGGIANO, Esdras; MATTOS, Cristiano. O desempenho de estudantes no Enem 2010 em diferentes regiões brasileiras. Rev. Bras. Estud. Pedagog, Brasília, v. 94, n. 237, p. 417-438, Ago. 2013.

WANDERLEY, Luiz Eduardo W. Universidades e sociedades: consensos e dissensos. Serviço Social \&Sociedade: São Paulo, 2005.

WHITAKER. A.C.D; FIAMENGUE. E.C. Ensino Médio: função do estado ou da empresa? Educação \& Sociedade, ano XXII, n. 75, Ago, 2001,

ZAGO, N. Pré-vestibular popular e trabalho docente: caracterização social e mobilização. Revista Contemporânea de Educação, Rio de Janeiro, v. 4, n. 8, 253274, dez. 2009.

ZANDONÁ, Norma da Luz. O espaço do contra poder: o acesso à universidade pública e o perfil socioeconômico educacional dos candidatos ao vestibular da UFPR. Tese. Curitiba, 2005. 


\title{
APENDICES
}

\section{APÊNDICE 1 - Solicitação de dados para pesquisa de Mestrado ao Decanato de Graduação da Universidade de Brasília - DEG/UnB.}

Brasília, 06 de outubro de 2014.

\author{
Ao Professor Mauro Rabelo
}

Decano de Graduação da Universidade de Brasília

Eu, Vânia Maria Lourenço,matrícula:13/0178551,aluna regular do Programa de Mestrado Profissional em Educação da Universidade de Brasília - Linha de Pesquisa: Gestão de Políticas e Sistemas Educacionais, venho pelo presente expor o que segue:

A fim de subsidiar minha pesquisa, solicitei a esse Decanato em 18/07/2014, dados acadêmicos de alunos ingressantes mediante cotas e sistema universal, constantes do CD em anexo, que estou devolvendo, uma vez que devido ao desenvolvimento do curso e aprofundamento na temática da democratização da educação brasileira, o meu objeto teve seu foco alterado.

Assim, venho solicitar novamente os préstimos de V. Sas no sentido de disponibilizar os dados abaixo especificados, para subsidiar minha atual pesquisa que tem como título "Limites e possibilidades do Exame Nacional do Ensino Médio - Enem, no processo de democratização da educação superior brasileira, a partir do rompimento da barreira geográfica."

A pesquisa tem como objetivo geral identificar em que medida o rompimento da barreira geográfica estabelecido a partir da reformulação do Enem, ocorrida em 2009, alterou o perfil racial, socioeconômico e regional do quadro discente ingressante nos cursos de graduação de medicina, engenharia, arquitetura e pedagogia da Universidade de Brasília, nos semestres 2013/2 e 2014/1.

Como objetivos específicos pretende-se :

1-Identificar se existe diferença no perfil racial, socioeconômico e regional dos alunos de graduação ingressantes na Universidade de Brasília (UnB), nos semestres 2013/2 e 2014/1, via Enem, em relação àqueles ingressantes mediante vestibular;

2- Averiguar em que medida o desempenho deingressantes na UnB via Enem e vestibular tradicional se diferencia.

Ao responder tais perguntas, será possível verificar em que medida o Enem, a partir do rompimento da barreira geográfica, minimiza a seletividade social e contribui efetivamente para o acesso de pessoas oriundas de classes menos favorecidas economicamente, à educação superior pública.

Para realização da pesquisa, que está sob a orientação da Professora da Universidade de Brasilia, Doutora Girlene Ribeiro de Jesus, que conjuntamente assina esta solicitação, será necessário o cruzamento de informações de desempenho individual dos alunos dos cursos 
pesquisados, com algumas variáveis socioeconômicas. Para tanto, solicitamos o acesso aos seguintes dados:

1- Índice de Rendimento Acadêmico - IRA dos alunos de graduação dos cursos de arquitetura, engenharia, medicina e pedagogia da Universidade de Brasília, ingressantes via vestibular no semestre 2013/2 e Enem, no semestre2014/1;

2- Desempenho no processo seletivo, bem como os microdados do QSC e QSE dos alunos ingressantes mediante vestibular, no semestre 2013/2 eEnem, no semestre 2014/1, nos cursos de graduação de direito, engenharia, medicina e pedagogia da Universidade de Brasília;

3- Relação dos alunos beneficiários pelo Programa Institucional de Bolsas de Iniciação Científica -PIBIC, ingressantes no 2013/2 e 2014/1, ingressantes mediante vestibular, no semestre 2013/2 e mediante Enem no semestre 2014/1, nos cursos de graduação de direito, engenharia, medicina e pedagogia da Universidade de Brasília;

Esta pesquisa será previamente submetida ao Comitê de Ética em Pesquisa do Instituto de Ciências Humanas da Universidade de Brasília, e serão seguidos todos os procedimentos e princípios de eticidade recomendados. Seus resultados serão divulgados unicamente em meios acadêmicos/científicos, mantendo-se a confidencialidade de todos os dados dos sujeitos da pesquisa. Ao Decanato de Ensino de Graduação será fornecida uma cópia da dissertação de mestrado contendo todos os resultados da pesquisa.

Esperando contar com a colaboração de V.Sa, colocamo-nos à disposição para quaisquer esclarecimentos.

Atenciosamente,

Vânia Maria Lourenço

Aluna
Profa Dra. Girlene Ribeiro de Jesus

Orientadora 


\title{
APENDICE 2 - Solicitação de dados para Pesquisa de Mestrado - DDS/UnB
}

Brasília, 10 de outubro de 2014.

\author{
À Professora Carolina Cássia Batista Santos \\ Diretora de Desenvolvimento Social da Universidade de Brasília
}

Eu, Vânia Maria Lourenço, matrícula 13/0178551, aluna regular do Programa de Mestrado Profissional em Educação da Universidade de Brasília - Linha de Pesquisa: Gestão de Políticas e Sistemas Educacionais, venho pelo presente, solicitar a V. Sa, os dados abaixo especificados, para subsidiar a pesquisa que tem como título "Limites e possibilidades do Exame Nacional do Ensino Médio - Enem, no processo de democratização da educação superior brasileira, a partir do rompimento da barreira geográfica."

A pesquisa tem como objetivo geral identificar em que medida o rompimento da barreira geográfica estabelecido a partir da reformulação do Enem, ocorrida em 2009, alterou o perfil racial, socioeconômico e regional do quadro discente ingressante nos cursos de graduação de medicina, engenharia, arquitetura e pedagogia da Universidade de Brasília, nos semestres 2013/2 e 2014/1.

Como objetivos específicos pretende-se:

1-Identificar se existe diferença no perfil racial, socioeconômico e regional dos alunos de graduação ingressantes na Universidade de Brasília (UnB), nos semestres 2013/2 mediante vestibularem relação àqueles ingressantes mediante Enem no semestre 2014/1.

2- Averiguar se o desempenho dos alunos ingressantes nos semestres 2013/2 e 2014/1,via Enem, nos cursos de arquitetura, engenharia, medicina e pedagogia da Universidade de Brasília, difere daqueles ingressantes via vestibular e PAS.

Ao responder tais perguntas, será possível verificar em que medida o Enem, a partir do rompimento da barreira geográfica, minimiza a seletividade social e contribui efetivamente para o acesso de pessoas oriundas de classes menos favorecidas economicamente, à educação superior pública.

Para realização da pesquisa, que está sob a orientação da Professora da Universidade de Brasilia, Doutora Girlene Ribeiro de Jesus, que conjuntamente assina esta solicitação, será necessário o cruzamento de algumas informações dos alunos dos cursos pesquisados, com algumas variáveis socioeconômicas. Para tanto, solicitamos a relação dos alunos beneficiários de bolsas permanência, ingressantes nos semestres2013/2 mediante vestibular, e aqueles ingressantesno semestre 2014/1, mediante Enem, nos cursos de graduação de direito engenharia, medicina e pedagogia da Universidade de Brasília; 
Esta pesquisa será previamente submetida ao Comitê de Ética em Pesquisa do Instituto de Ciências Humanas da Universidade de Brasília, e serão seguidos todos os procedimentos e princípios de eticidade recomendados. Seus resultados serão divulgados unicamente em meios acadêmicos/científicos, mantendo-se a confidencialidade de todos os dados dos sujeitos da pesquisa. À Diretoria de Desenvolvimento Social da UnB, será fornecida uma cópia da dissertação de mestrado contendo todos os resultados da pesquisa.

Esperando poder contar com a colaboração de V.Sa, colocamo-nos à disposição para quaisquer esclarecimentos.

Atenciosamente,

Vânia Maria Lourenço

Aluna
Prof $^{a}$ Dra. Girlene Ribeiro de Jesus

Orientadora

\section{APENDICE 3 - Questionário aplicado aos participantes da pesquisa para identificar em que medida as políticas de permanência oferecidas pela UnB tem contribuído para a permanência dos alunos.}

\section{Questionário}

Prezado aluno, Meu nome é Vânia Lourenço. Sou servidora da Universidade de Brasília e mestranda do Programa de Políticas Públicas em Educação na mesma instituição. Minha pesquisa tem como foco o Exame Nacional do Ensino Médio - Enem e busca investigar em que medida o exame tem alterado o perfil socioeconômico e regional do quadro discente da UnB e se as políticas de permanência têm contribuído para a permanência dos alunos. A sua participação é opcional e não levará mais que dez minutos. Entretanto, será de suma importância para meu trabalho. Sua identidade não será divulgada em hipótese alguma e os dados coletados terão utilidade exclusivamente acadêmica. Desde já, agradeço sua colaboração e coloco-me à disposição para quaisquer esclarecimentos, através do e-mail vanial2010@gmail.com

Ciente do objetivo deste questionário?

Assinale que você concorda em participar, de forma voluntária e anônima, deste questionário.

( ) Sim

( ) Não

Bloco I

1- Qual o semestre que você ingressou na UnB?

2- Qual o seu curso? 
3- Por qual forma você ingressou na UnB?

( ) Vestibular

( ) Exame Nacional do Ensino Médio - Enem

( ) PAS

4- De que cor/raça você se autodeclara?

( ) Amarela

( ) Branca

( ) Preta

( ) Parda

( ) Indígena

5- Em que região você nasceu?

( ) Centro-Oeste

( ) Norte

( ) Nordeste

( ) Sul

( ) Sudeste

( ) Em outro País

6- Onde você morava antes de ingressar na Universidade de Brasília?

( ) Em Brasília, no Plano Piloto

( ) Em outra cidade do Distrito Federal

( ) Na cidade onde nasci

( ) Outra cidade.

7- Qual o nível de escolaridade de seu pai?

( ) Sem escolarização

( ) Fundamental incompleto

( ) Fundamental Completo 
( ) Médio incompleto

( ) Médio Completo

( ) Superior incompleto

( ) Superior Completo

( ) Especialização

( ) Mestrado

( ) Doutorado

8- Qual o nível de escolaridade de sua mãe?

( ) Sem escolarização

( ) Fundamental incompleto

( ) Fundamental Completo

( ) Médio incompleto

( ) Médio Completo

( ) Superior incompleto

( ) Superior Completo

( ) Especialização

( ) Mestrado

( ) Doutorado

9- Qual a renda mensal de sua família?

( ) Menos de um salário mínimo

( ) De um a dois salários mínimos

( ) De três a quatro salários mínimos

( ) De cinco a seis salários mínimos

( ) De sete a dez salários mínimos

( ) De onze a quatorze salários mínimos

( ) Acima de quatorze salários mínimos

( ) Não sei responder

10- Onde você cursou o ensino médio?

( ) Na rede pública 
( ) Na rede privada

( ) Parte na rede pública e parte na rede privada

Bloco II

1- Em relação ao seu rendimento no curso, teve reprovações?

( ) Sim

( ) Não

2- Você já trancou alguma disciplina?

() Sim

( ) Não

3- Você esteve em processo de condição de desligamento?

( ) Sim

( ) Não

Como você avalia o apoio que a UnB proporciona aos alunos com dificuldades acadêmicas
( ) Excelente
( ) Bom
( ) Razoável
( ) Ruim
( ) Péssimo

Bloco III

1- Você conta com o auxílio financeiro da familiar para manter-se na universidade?

( ) Sim.

( ) Não

2- Você exerce alguma atividade profissional remunerada?

( ) Não

( ) Faço estágio remunerado

( ) Sim. Trabalho no horário inverso das aulas 
3- Você utiliza o restaurante universitário?

( ) $\operatorname{sim}$

( ) não

( ) Algumas vezes

4- Qual o meio de transporte que você utiliza para chegar à universidade?

( ) automóvel

( ) ônibus

( ) bicicleta

( ) taxi

( ) não utilizo. Vou a pé.

5- Você é beneficiário de alguma política de permanência na Universidade?

( ) Sim. Qual?

( ) Não

6- Com qual (is) política de permanência você foi contemplado?

Programa Bolsa Alimentação

Programa Auxílio Alimentação ( )

Programa Auxílio Socioeconômico $(1)$

Programa Moradia Estudantil da Graduação )

Bolsa Permanência MEC

Programa Auxílio Emergencial $(\quad)$

Nunca solicitei $(\quad)$

Já solicitei, mas não fui contemplado - $(1)$ 
7. Em que medida o acesso a esta (s) política (s), tem favorecido a sua permanência na Universidade?

( ) Muito. Sem ela (s) dificilmente me manteria

( ) Ajuda, mas não o bastante

( ) Não faz muita diferença

8- Que melhorias você considera que devem ser realizadas nas atuais politicas de permanência da UnB já implementadas pela UnB ou que outras políticas considera que deveriam ser implementadas? 